This PDF is a simplified version of the original article published in Internet Archaeology. Enlarged images and data which support this publication can be found in the original version online. All links also go to the online version.

Please cite this as: Brownlee, E. 2021 Grave Goods in Early Medieval Europe: regional variability and decline, Internet Archaeology 56. https://doi.org/10.11141/ia.56.11

\title{
Grave Goods in Early Medieval Europe: regional variability and decline
}

\section{Emma Brownlee}

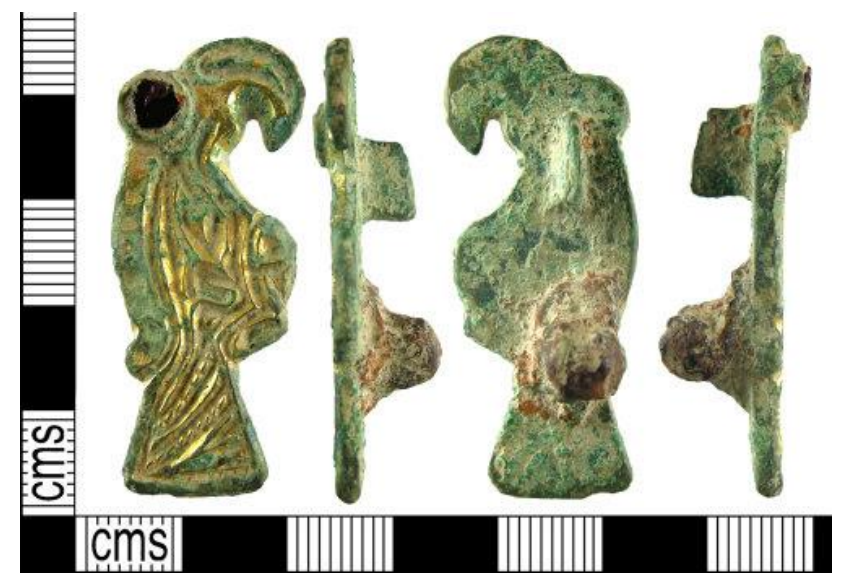

An incomplete early early-medieval (Anglo-Saxon, c.500-600) gilded copper-alloy zoomorphic plate bird brooch with garnet eye detail from Hampshire. Image: Hampshire Cultural Trust (CC BY 4.0). See K. Hinds 2017 HAMP-OABB4E: A EARLY MEDIEVAL BROOCH https://finds.org.uk/database/artefacts/record/id/859161

This article analyses the use of grave goods in burials across early medieval Europe and how that use changed over the course of the 6th to 8th centuries CE with the widespread transition to unfurnished burial. It uses data gathered from published cemetery excavation reports from England, France, Germany, Belgium, Switzerland, and the Netherlands. The grave good use in these cemeteries was analysed using GIS methods to visualise regional differences, as well as statistical methods to analyse how grave good use evolved over time in those regions.

This analysis revealed clear regional distinctions in grave good use, with England and Alamannia appearing similar, with relatively high levels of grave good use. Meanwhile, parts of Frankia and of Burgundy had considerably lower levels of grave good use. Distributions of individual artefact types tended to match those of overall numbers, but there were a few key exceptions, such as vessels, which followed a quite different 
pattern, being found in high numbers along the Frankish coast, but in much lower numbers elsewhere. Despite these overall trends, there was still considerable intraregional and intra-cemetery variation that suggests communities and individuals had the ability to make highly individual choices about the way to bury their dead, along with the ability to subvert local norms.

It also revealed that while there was a general decline in the use of grave goods across this period, and everywhere eventually reached the point of almost completely unfurnished burial, this decline occurred at different rates. In particular, there was a zone around the North Sea, including Kent, western Frankia, and the Low Countries, where there was little change in grave good use until it was suddenly abandoned in the early 8th century. Different types of objects declined at different rates across different regions, with few clear trends, suggesting that only personal accessories held a common significance across Europe; the meanings of all other object types were negotiated on a local basis.

\section{Introduction}

One of the most dramatic transformations in funerary practices across western Europe was the transition from furnished to unfurnished inhumation in the 6th to 8th centuries $\mathrm{CE}$. This was a widespread change, and looking at the broadest of scales, the way in which different areas adopted a largely unfurnished burial rite appears reasonably similar. The beginning of the decline can be dated to the mid-6th century; numbers of unfurnished burials increased rapidly towards the end of the 7th century, and by the early 8th century, unfurnished burial was overwhelmingly favoured (Brownlee 2021). However, this apparently simple narrative hides a great deal of regional variability in how different communities approached the changing norms in burial rites; the change did not take place at the same pace in all areas of western Europe, nor did all types of objects decline at the same rates. This article will illustrate such regional differences, starting with an overview of grave good preferences in inhumations across Europe in the 6th century, and then looking at the way such provisions changed over time.

Grave good use in early medieval Europe has thus far only been characterised on a small scale; previous studies, which have analysed grave good use and its decline over the course of the 7th and 8th centuries, have been conducted primarily at a regional scale and have been very much constrained by modern national borders. Yet these borders have little to no relevance to the early medieval past and limiting a study in such a way means that larger-scale cultural connections have been missed. This article will, for the first time, characterise grave good use across early medieval north-western Europe, highlighting key regional distinctions, as well as investigating the potential for variation from the regional norm. It will then look at how those patterns of grave good use evolved over the course of the 7th and 8th centuries. Burial change across this period has long been viewed as a simple trajectory from a variable, furnished burial rite, to a much more standardised shrouded burial in a churchyard. Changes in the funerary rite have thus been interpreted within that framework, but with little investigation into the processes of change. This article will focus on that process of change, analysing how unfurnished burial came to be adopted in different regions. There are, of course, many other aspects of the funerary rite besides grave good deposition, and funerary variation continued to exist past the 8th century CE, in terms of body position, the use of 
containers, above-ground monuments, location, and even the occasional provision of objects (Hadley 2011). Yet the widespread adoption of unfurnished burial can be seen as a form of standardisation in this one aspect of the funerary rite.

\subsection{Furnished inhumation in the 5th and 6th centuries CE}

The practice of clothed burial with grave goods emerged across Europe in the mid-4th to 5th century, and much of the debate around its origins has focused on the question of whether it was an evolution of late Roman practices, or whether it was a custom imported by migrating ethnic groups (see Halsall 1992 for a summary of the debate in a Frankish context; Hills 2003 for an Anglo-Saxon context). In the late 4th and 5th centuries, Reihengräberfelder, or 'row-grave cemeteries', appeared across much of Europe, containing far more grave goods than their sparsely furnished predecessors (Halsall 1998, 335; Theune 2004, 38). From the middle of the 4th century onwards, weapons, belt accessories, brooches, and jewellery began to be deposited in graves in gradually increasing numbers (Theuws $\underline{2009}$, 286-7). This was not a complete replacement, and unfurnished inhumation continued to be used alongside furnished burial throughout the entire medieval period, without any indication that the rites represented separate 'Roman' and 'Germanic' groups (Halsall 1992; Theuws $\underline{2009}$, 284). Object deposition was highly variable; this variation was to some extent based around identities such as gender and age, but was not homogeneous even within these categories, and there are clear regional variations (Halsall 1998, 327, 331). Previous analysis of grave good variation has tended to focus on variation as an indicator of ethnicity; for example, Siegmund (1998, 182-91) interprets variations in weapon use and vessel use across France and Germany as being an indicator of Frankish, Alamannic, and Saxon ethnic groups. Analysis has largely moved away from simple ethnic interpretations, emphasising instead the variability of the funerary record (e.g. Theune 2004, 355-56), and some questioning whether or not it is even possible to access ethnic identities in the archaeological record (e.g. Brather 2002, 174-5; Harland 2019). This article deliberately does not take an ethnic approach; although the analysis necessitates dividing the study area into different regions, these should not be equated with groups with distinct ethnic identities. Rather, similarities and differences can be used to illustrate points of contact and affinity between the people of different regions without making an assessment of ethnicity. I have avoided the use of modern labels to distinguish between different regions; they are anachronistic, and can encourage interpretations of population continuity between the early medieval period and modern times, something particularly problematic in a far-right context. However, terms such as 'Frankish' or 'Anglo-Saxon' also carry problematic connotations. Therefore the use of ethnic labels to refer to geographical areas throughout this article is intended as a shorthand for a particular geographic area with distinct practices, and should not be taken to imply anything about the ethnic identities of those living there.

\subsection{Seventh-century burial}

Following the peak in grave good use in the 5th and 6th centuries, the 7th century was a period of transformation in burial rites, in terms of the types of cemeteries in use, and the numbers, types and styles of grave goods used. 
One of the key transformations in the 7th century was a shift in mortuary geographies; a change in the types and locations of cemeteries that were favoured, as well as diversification of burial locations. The 7th century saw the gradual abandonment of the larger field cemeteries in favour of smaller cemeteries, sometimes associated with churches or chapels (Theune 2004, 268; Loveluck 2013, 34; Czermak et al. 2006, 298), but sometimes associated with settlements (Theuws 1999). At the same time, isolated burials appear, many in prominent places in the landscape, and under barrows (Scull 2013, 528). In England, these later, smaller, often poorly furnished cemeteries did not have associated churches, as their equivalents on the continent could do (Blair 2005, 64, 236-7), and have historically been referred to as 'final-phase' cemeteries, associated with Christianisation (e.g. Lethbridge 1931, Hyslop 1963). However, this religious identification, and the predominance of this type of cemetery during the 7th century have been heavily critiqued. While many cemeteries did go out of use, and were replaced by newer, smaller ones, this was not a simple transition from one form to the other (Blair 2005, 238; Buckberry 2010, 2; Hadley 2002, 210), and many earlier cemeteries continue to be used into the 7th century (Scull $\underline{2015}, 78$ ).

But the most defining feature of the change in burial practices was the decline in grave good deposition, something that has been observed at different levels across much of Europe. Across Frankia and Alamannia, there was a gradual decrease in the practice of placing objects with the dead over the 6th and 7th centuries, something that accelerated in the phase c. 670-c. 720, so that by the first half of the 8th century, furnished burial had been almost completely abandoned (Effros 2003, 85; Halsall 1995, 15; Theune 1999, $29,32)$. There were some areas around the Lower Rhine where well-furnished burials continue into the 8th century, but this was unusual (Bullough 1983, 185). In England, earlier studies, such as Geake (1997), suggested a very similar chronology to the continent; grave good use began to decline around the middle of the 7th century, and was totally abandoned by $720-730$ (Geake 1997, 130). This timeline has been refined by a recent study that dated the start of the decline to 560-570, and the final abandonment to 685, considerably earlier than on the continent (Hines and Bayliss 2013, 476-9). Following this final abandonment, the occasional object was still deliberately deposited with the dead, and was so throughout the entire later medieval period (Hines and Bayliss 2013, 526; Corrochano and Soulat 2017, 99-100), but this was far from the levels of deposition we see earlier.

Previous studies have already indicated that the decline in grave good deposition was not steady or uniform. The types of object deposited became less varied, being restricted mainly to dress accessories from the 7th century onwards (Halsall 1998, 336), as well as objects such as knives (Welch 2011, 267). On the whole, grave good deposition became more representative of a socially stratified society, with a few furnished graves contrasting with a majority of unfurnished ones (Koch $\underline{1968}, 132$ ). Some of these burials were richly furnished 'princely' burials, such as Sutton $\mathrm{Hoo}$ and Prittlewell (Boddington 1990, 189; Burnell and James 1999, 90). Although furnished female burial decreased towards the end of the 6th century, they became six times as common as richly furnished male burials in the mid-7th century, while most male burial remained poorly furnished (Hines and Bayliss 2013, 476-9, 539). Overall, the display of gender became less common in the 7th century, although children became increasingly likely to be buried with objects that previously would only usually have been included in adult graves (Geake 1997, 128-9). In England in the 5th to 6th centuries, approximately $53 \%$ of burials were gendered, while in the 7th century this fell to as low as $10-20 \%$, and a similar change has also been noted in Frankish burials (Halsall 1996, 12; Scull 2015, 77; Stoodley 1999, 101). Again, these observations are based on limited regional 
studies, themselves based on data collected in different ways, with different levels of completeness, making them hard to compare. A broader approach is needed to understand the way in which unfurnished burial came to be the continent-wide norm.

This article will systematically examine the way in which grave good use varied at the peak of its use, in the 6th century. It will investigate the key differences between regions, without attempting to link them to pre-determined ethnic identities, as so many previous studies have done, but examine such distinctions in terms of the agency of communities to follow or subvert regional norms. It will then investigate the way in which grave good use changed from this initial peak, whether we see a gradual decline in grave goods, or a sudden change, and how this manifested in different object types. Characterising funerary change over a large area in this way has the potential to reveal new insights into the extent to which a shared understanding of death and the funerary ritual existed beyond the regional boundaries through which they are usually studied.

\section{Materials and Methods}

The following analysis is based on a dataset of 205 cemeteries in use during the 6th to 8th centuries, from six modern-day countries. Cemeteries were selected for which grave catalogues and accurate chronological information were available. For each site, the number of objects per grave was recorded, as well as the presence or absence of each category of object, according to the categories outlined in Table 1. These categorisations of objects are deliberately broad, for the practical reason of maintaining a viable sample size for each, but also for theoretical reasons. I am concerned with why objects were included in the grave, and the different role that they may have played in the funerary rite. Different styles of brooch, for example, or the distinction between brooches and belt buckles, are far less informative on this question than whether or not the corpse is buried clothed or shrouded.

There are still ambiguities in some of these classifications; the distinction between dress accessories and jewellery is an unclear one, for example, but the fact that these categories are used in different ways (see Section 3.2 and Section 5.2) suggests that some distinction did exist in the early medieval period. Other categories that have been grouped together may also have fulfilled separate functions; 'weapons' implies a military function, while objects such as axes and bows and arrows can also be used in domestic contexts (Theuws 2009, 301-5). Animal remains could have been included in the grave as a food offering, as a status symbol or as apotropaic items (Rainsford 2021). As distinguishing between these different functions is difficult, they have been left as one category, however. Of course, the objects that were excavated and recorded are not a complete record of the objects originally deposited in the grave. Except in a very few instances, organic objects have largely decayed, and graves may have been affected by later disturbance, both deliberate and accidental. The numbers discussed below, therefore, are more of a measure of relative levels of furnishing rather than an accurate reflection of the number of objects initially deposited. Cemeteries with exceptional organic preservation, such as Oberflacht (Schiek 1992), have not been included as they cannot be compared to the majority without such preservation. I have also avoided making an assessment of the value of the objects, focusing purely on numbers. All of the sites used in this study, along with the data associated with them, are displayed in Figure 1. 
Table 1: Categories of grave goods (Brownlee 2020, table S1)

\begin{tabular}{|c|c|c|}
\hline Category & Description & $\begin{array}{l}\text { Object } \\
\text { types }\end{array}$ \\
\hline $\begin{array}{l}\text { Dress } \\
\text { accessories }\end{array}$ & $\begin{array}{l}\text { Objects that were part of an everyday costume. These are } \\
\text { usually inalienable possessions. }\end{array}$ & $\begin{array}{l}\text { Buckles Belt } \\
\text { fittings } \\
\text { Buttons } \\
\text { Shoe fittings } \\
\text { Wrist clasps } \\
\text { Brooches }\end{array}$ \\
\hline Jewellery & $\begin{array}{l}\text { Items that embellish dress but are not essential to it; there } \\
\text { is some overlap with dress accessories. These are usually } \\
\text { inalienable possessions. }\end{array}$ & $\begin{array}{l}\text { Beads } \\
\text { Finger rings } \\
\text { Necklaces } \\
\text { Earrings } \\
\text { Arm rings } \\
\text { Hairpins }\end{array}$ \\
\hline $\begin{array}{l}\text { Personal } \\
\text { accessories }\end{array}$ & $\begin{array}{l}\text { Items for personal use, which could have been carried on } \\
\text { the person. These are usually inseparable possessions. }\end{array}$ & $\begin{array}{l}\text { Knives Fire- } \\
\text { steels and } \\
\text { flints Keys } \\
\text { Spoons } \\
\text { Bags Girdle } \\
\text { hangers }\end{array}$ \\
\hline Tools & $\begin{array}{l}\text { Items that could have been carried on the person, but } \\
\text { have a more specific purpose, suggesting that they may } \\
\text { not have been carried as regularly as other personal } \\
\text { accessories. }\end{array}$ & $\begin{array}{l}\text { Awls Burins } \\
\text { Hooks } \\
\text { Spatulas } \\
\text { Needles } \\
\text { Quernstones } \\
\text { Spindle } \\
\text { whorls } \\
\text { Scales }\end{array}$ \\
\hline Weapons & $\begin{array}{l}\text { Weapons, but also elements of armour; this is included } \\
\text { here rather than in dress accessories because they are } \\
\text { unlikely to have formed part of everyday dress. These are } \\
\text { usually inalienable possessions. }\end{array}$ & $\begin{array}{l}\text { Spathae } \\
\text { Spears } \\
\text { Saxes } \\
\text { Arrows } \\
\text { Shields } \\
\text { Axes } \\
\text { Chainmail } \\
\text { Helmets } \\
\text { Scabbards } \\
\text { Spurs }\end{array}$ \\
\hline $\begin{array}{l}\text { Toilet } \\
\text { accessories }\end{array}$ & $\begin{array}{l}\text { Items of personal grooming; they have been separated } \\
\text { from personal accessories because of their specific } \\
\text { function. These could be inalienable possessions. }\end{array}$ & $\begin{array}{l}\text { Tweezers } \\
\text { Combs } \\
\text { Razors } \\
\text { Shears Ear } \\
\text { spoons }\end{array}$ \\
\hline
\end{tabular}




\begin{tabular}{|c|c|c|}
\hline Vessels & $\begin{array}{l}\text { Containers of all types, either for consumption or storage. } \\
\text { Pottery sherds were included when it was suggested that } \\
\text { they had come from a vessel placed in the grave, rather } \\
\text { than being residual. }\end{array}$ & $\begin{array}{l}\text { Glass } \\
\text { vessels } \\
\text { Pottery } \\
\text { vessels } \\
\text { Metal } \\
\text { vessels } \\
\text { Plates } \\
\text { Buckets } \\
\text { Wooden } \\
\text { boxes }\end{array}$ \\
\hline $\begin{array}{l}\text { Animal } \\
\text { remains }\end{array}$ & $\begin{array}{l}\text { Animals buried with the deceased, or a single bone, which } \\
\text { could indicate a food offering. }\end{array}$ & $\begin{array}{l}\text { Animal } \\
\text { bones } \\
\text { (single or } \\
\text { articulated) } \\
\text { Egg shells }\end{array}$ \\
\hline Amulets & $\begin{array}{l}\text { Objects which had an apotropaic function, from both a } \\
\text { Christian and a non-Christian context. }\end{array}$ & $\begin{array}{l}\text { Animal teeth } \\
\text { Pebbles } \\
\text { Amulets } \\
\text { Figurines } \\
\text { Christian } \\
\text { crosses } \\
\text { 'Work-boxes' }\end{array}$ \\
\hline Fittings & $\begin{array}{l}\text { Usually metal objects that formed part of larger, } \\
\text { unidentified objects. }\end{array}$ & $\begin{array}{l}\text { Fittings } \\
\text { Metal rings } \\
\text { Ornamental } \\
\text { discs Nails }\end{array}$ \\
\hline
\end{tabular}

Figure 1: Sites used in this study. All data are also available for download

Interactive map only available online

For furnished cemeteries, five main chronological schemes were relied on: Hines and Bayliss 2013; Legoux et al. 2004; Müssemeier et al. 2003; Koch 2001; Hakenbeck 2011. These all used seriation and correspondence analysis to group graves into phases, which were then assigned absolute dates on the basis of coins or dendrochronological dates in the case of Legoux et al. 2004 and Müssemeier et al. 2003, or radiocarbon dates in the case of Hines and Bayliss 2013. The absolute dates in Hakenbeck (2011, 50) were generated through comparison with those of Koch 2001 and Müssemeier et al. 2003, with only a few coins from those graves to support these conclusions. Despite having become the primary chronological scheme for south-west Germany, Koch's chronology has been criticised for its opaque methodology, with little detail given on exactly how the phases were constructed (Friedrich 2016, 5-6). However, Hines and Bayliss $(\underline{2013}, 480)$ suggest that it is broadly comparable with their chronological scheme, alongside Legoux et al. $\underline{2004}$ and Müssemeier et al. 2003. While almost all of the furnished cemeteries in this study from England were dated using Hines and 
Bayliss $\underline{2013}$, those from other parts of Europe had to be supplemented with cemeteries based on more traditional typo-chronologies. This means that while all of the English cemeteries are broadly comparable to each other and to some cemeteries on the continent, the same is not true of France and Germany, where cemeteries dated using complex analyses sit beside those dated using more traditional methods

(Brownlee 2021, 145). For unfurnished cemeteries, radiocarbon dating is the only way of obtaining absolute dates. Given the small sample of graves usually selected for radiocarbon dating, it is probable that the true lifespan of the cemetery differs from that suggested by the radiocarbon dates. The same is true of dates assigned on the basis of typologies; we cannot rule out earlier or later graves that contained no or few diagnostic artefacts. In the following analysis, therefore, the earliest possible known date and latest possible known date are the ones used. The chronological information available for each site is provided in Figure 1.

This study also focuses solely on inhumation rather than cremation. The different nature of the cremation rite meant that grave goods were introduced at different stages of the process. Some objects were burnt on the pyre with the body, while some were added afterwards, and it is important to distinguish between these, as they are likely to have had quite different significances (McKinley 2013, 150). This is reflected in the quite different types of grave goods that are favoured in inhumation versus cremation rites; weapons were rarely included in cremation rites, but cosmetic implements such as combs and tweezers were much more commonly found (Williams 2005). Therefore I have chosen to analyse grave good use within inhumations only, to avoid this added level of complexity.

Initial patterns of grave good use in Europe were analysed using relative kernel density estimates (KDEs), and hot spot analyses, of all the cemeteries in use during the 6th century, created using the methods outlined in Brownlee (2021). To summarise, the kernel density maps indicate concentrations of points, which can be weighted based on certain characteristics; in this instance, the numbers of graves in a cemetery containing a certain type of object. The hot spot analyses indicate clusters of statistically significant high or low levels of grave good use, 'hot spots' and 'cold spots'. These maps indicate the levels of grave good use relative to numbers of cemeteries, so that areas of intense archaeological investigation do not appear over-represented. Figure 2 demonstrates the step-by-step methodology in ArcGIS 10.5.1. Following this, edge effects were manually removed from the resulting KDEs.

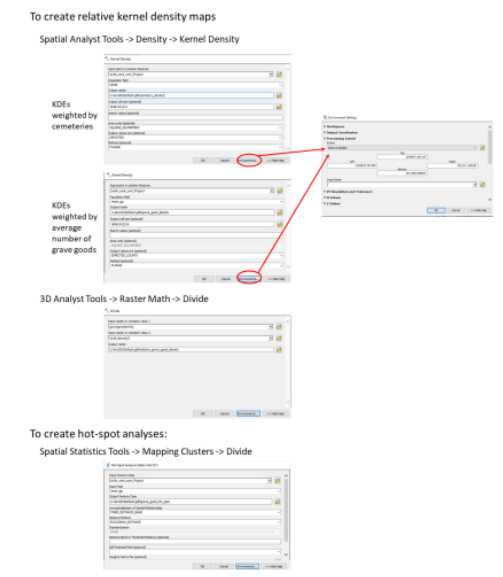

Figure 2: Creating relative KDEs and hot spot analyses in ArcGIS 
Intra-regional variation in 6th-century grave good use was then assessed with the use of violin plots to show the range of such use within cemeteries in each of eleven different regions: southern and northern Alamannia, Bavaria, western and eastern Frankia, Burgundy, the Lower Rhine, the Moselle and Low Countries, Kent, and Anglian and Saxon regions of England (Figure 3). I have not analysed Northumbrian cemeteries, as the relatively low number of well-dated graves in that area hampered attempts at statistical analysis. Thuringia has also been excluded owing to the poor chronological resolution from that area, and other sites that fall outside the regions outlined have also not been analysed further. Violin plots are an alternative to box-plots, which better represent the shape of the data, allowing the exact position and shape of peaks to be seen, rather than just the mean and interquartile range of the data. Combined with the jitter plot, showing the actual values for each site, they display the overall distribution of the data in a more realistic way than do box-plots.

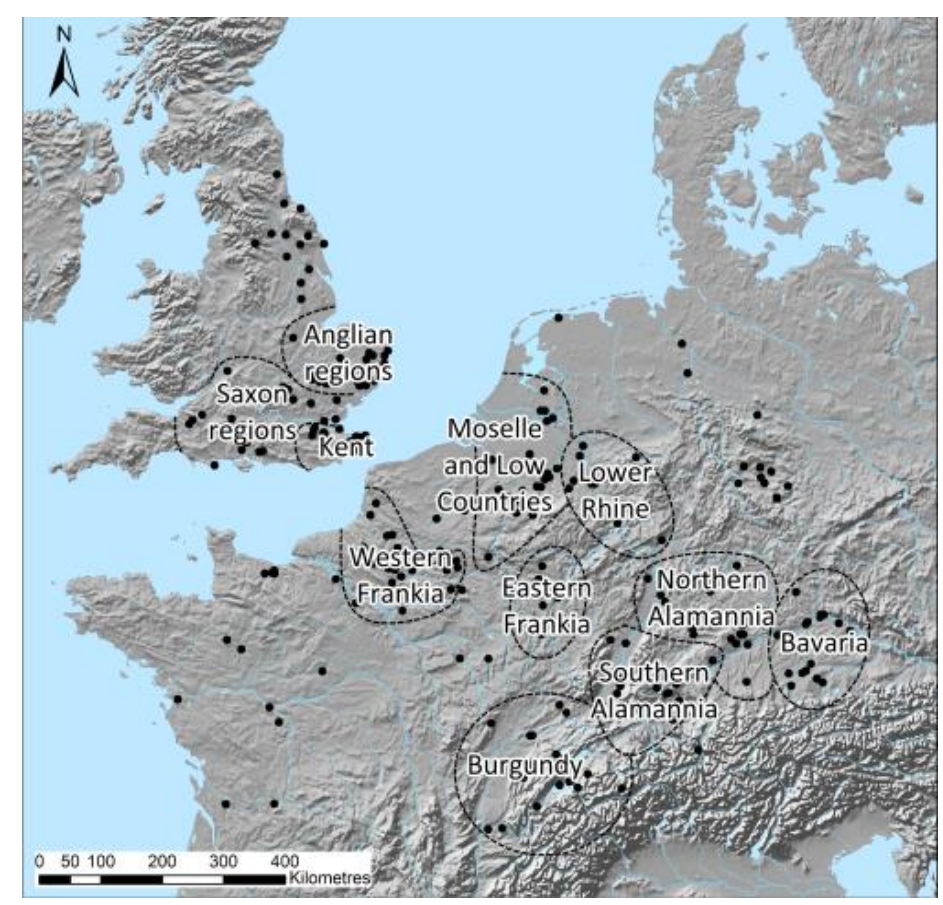

Figure 3: The regions used for analysis

Following this initial survey of grave good use in the 6th century, the way in which it changed in the 7th and 8th centuries is explored, first through an analysis of the chronological spans of cemeteries, and then through a statistical analysis of trends in grave good use over time. I compared the number of objects per grave against the latest known date a cemetery was in use, using a Spearman's rho correlation. This test looks at the strength of correlation between two numeric variables, in this case the last known date of a cemetery's use, and the number of objects per grave. It produces an rs-value, indicating the strength of the correlation, and a P-value, indicating the statistical significance. If there was a steady decrease in grave good deposition over time, then cemeteries that continued to be used later should have a lower average number of objects, as they will contain a higher proportion of later, unfurnished graves. This approach has some drawbacks; all of the graves from one cemetery were labelled with the same date, which in many cases would have been later than the actual date of each grave. This diluted the effect of date on grave good deposition, meaning that the rsvalue produced by Spearman's rho will have been artificially lowered, implying weak correlations that will have been stronger in reality. Yet this is unavoidable if we want to 
make use of the large numbers of undated graves, which are usually the poorly furnished ones. At this point, only those cemeteries with the most secure dating evidence were included, with fourteen sites being removed from the analysis, largely from Bavaria and Burgundy. Another issue is the potential for relative inaccuracies between the different schemes used across continental Europe will especially have affected the Spearman's rho test: if, for example, one cemetery were to be placed ten years later than another, when in reality it had gone out of use ten years earlier, all that the test would register would be a difference in order, and not the fact that these two cemeteries were very close in date. This issue is avoided with all of the English sample, though; given that they were all dated using the same methods, we can be confident in their relative dates.

The same approach was taken for each type of object within the cemeteries. The presence or absence of a particular object type in a grave was correlated against the year a cemetery went out of use, and the statistical significance was tested using a Kendall's tau-b test. This test performs the same function as a Spearman's rho, but is more appropriate when one of the variables is binary. It produces a $T_{b}$-value, equivalent to the rs-value in Spearman's, which indicates the strength of the correlation, and a Pvalue indicating statistical significance. This test was performed only on cemeteries from the main period of furnished burial, with those largely unfurnished cemeteries, which appeared during the 8th century, not included. This was to make sure that the tests indicated the change in grave good use that occurred before such use was entirely abandoned, to illustrate whether the change was a gradual decline, or a sudden shift.

Unless otherwise indicated, all maps were created in ArcGIS 10.5.1, with base maps downloaded from Natural Earth. All graphs were created, and all statistical analysis was done in $\mathrm{R}$ 3.6.3. The data used to create the graphs are also provided as [all graves.csv, all cemeteries.csv, and all cem types.csv], and the R code used to create the graphs and carry out the statistical analyses is provided as [Code EM grave goods. R].

\section{Funerary Variability Across Europe 3.1 Overall levels of furnishing}

Although large parts of western Europe practised the furnished inhumation rite, there was nevertheless a great deal of variation in the range and nature of grave goods provided. In continental Europe, there was a division between the sparsely furnished cemeteries further south, which had low, almost negligible, levels of grave good use and particular cold spots over Burgundy, and the core of furnished burial further north. There, grave good use was higher, particularly in Alamannia, with relatively high levels also existing in England (Figure 4; Brownlee 2021, 147). 


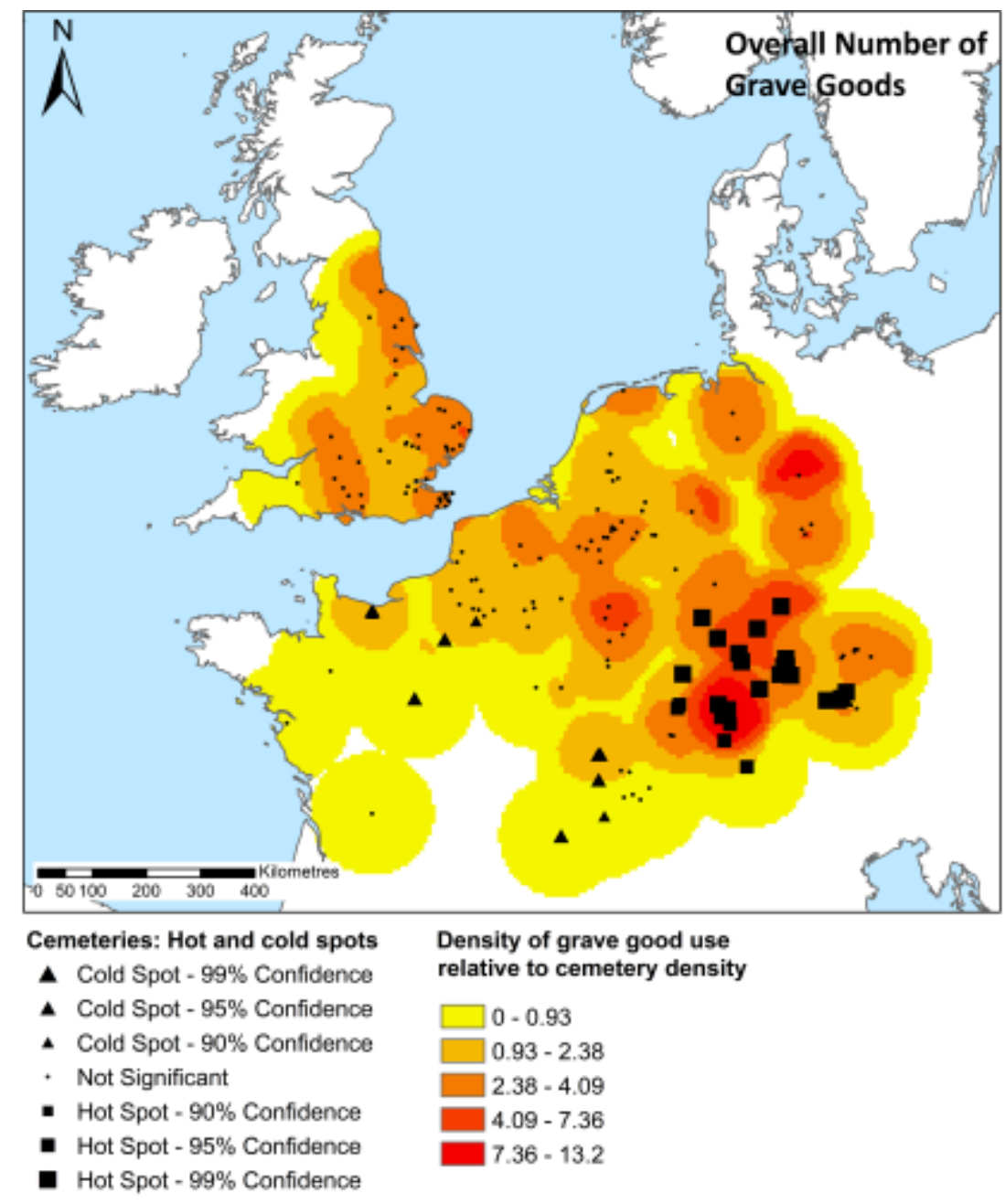

Figure 4: Relative kernel density map of grave good use in the 6th century, showing high concentrations over Alamannia and eastern England, and low concentrations over western Frankia and Burgundy

These kernel density maps indicate the average levels of grave good use over a region, but also mask the considerable intra-regional variability that existed. It is necessary to distinguish between a hot spot caused by a few extremely rich cemeteries that coexisted alongside more poorly furnished ones, or a general tendency towards higher deposition across one region compared to others.

The regions with the high level of grave good use, the Anglian parts of England (Figure $\underline{5}$ ), and Alamannia (Figure 6, Figure 7) contained cemeteries that on the whole had a wide range of grave good deposition, with an average number of 3-4 objects per grave. The cemeteries that came into use towards the end of the 6th century, especially Burwell (Lethbridge 1931), Shudy Camps (Lethbridge 1936), and Bloodmoor Hill (Lucy et al. 2009) in Anglian areas, and Sainte Barbe (Blaizot et al. 2004) in southern Alamannia, had more of a skew towards no or very low numbers of objects, but there were still some richer graves present. There are some distinctions between the regions, particularly when it comes to the provision of the richest graves. Almost all Anglian sites had some graves that stood out as particularly well furnished, but the Alamannian sites were more variable; some also contained these rich burials, while others had more restricted object use. While there was variability of practice within a cemetery, there was also considerable variation between cemeteries within a region. 
The cemeteries of Bavaria (Figure 8) had lower maximum numbers than neighbouring Alamannia. Some cemeteries tended strongly towards low numbers of grave goods, while others had more variety in the levels of furnishing. The cemeteries with different levels of furnishing also cluster within Bavaria; the richer sites in the region were all located along the River Danube (Figure 9), while the cemeteries on the Munich plain all had consistently lower levels of furnishing.

The regions where grave good use was much lower showed markedly different profiles; each cemetery had a lower maximum number of grave goods, with unfurnished graves forming a higher proportion of burials at the site, leading to much less inter-cemetery variation than in other areas. However, there were distinct differences between western Frankish (Figure 10) and Burgundian sites (Figure 11); in Burgundian cemeteries, unfurnished burials dominated, and the inclusion of grave goods was relatively rare. Saint Vit, one of the earliest cemeteries, was something of an anomaly, with markedly higher grave good deposition, more variability, and a far lower proportion of unfurnished graves. It has been suggested that the greater investment in graves at Saint Vit was because of its strategic location on the River Doubs, which made it an important site for the recent Frankish conquerors to display their status (Urlacher et al. 2008, 269), though there were other cemeteries on the Doubs that did not show such high investment. West Frankish cemeteries, on the other hand, were more likely to have low numbers of objects in their graves, although there were a few sites that were dominated by unfurnished burial. Their maximum numbers were much reduced compared to the Alamannian and Anglian sites, with burials including over ten objects rare.

In the cemeteries of Kent (Figure 12), the Lower Rhine (Figure 14), the Low Countries (Figure 15) and eastern Frankia (Figure 16), there was noticeable variety in grave good provision, with broad fluctuations in the average number of grave goods deposited, though those in the Low Countries had lower numbers on the whole. The typical range deposited in graves also varied greatly between cemeteries. Those on the Lower Rhine tended towards higher maximum numbers, perhaps reflecting their proximity to the more richly furnished cemeteries of Alamannia, while those in eastern Frankia tended to be lower, reflecting their greater proximity to the sites of western Frankia. The cemeteries on the Lower Rhine and eastern Frankia in particular varied between those that were dominated by unfurnished burials, and those with more variety in the numbers of objects being used. While the few cemeteries excavated in western Kent were generally more poorly furnished than those of the east, the eastern cemeteries also show a great deal of variation, with relatively poor sites existing alongside relatively rich ones (Figure 13). In the Low Countries, those cemeteries found further north and closer to the coast tended to be poorer, but there were also plenty of similarly poorly furnished cemeteries further inland, in close proximity to richer sites (Figure 17).

In contrast to these areas, cemeteries in the Saxon regions of England appear to have been more standardised, with little variation between cemeteries (Figure 18). Although their maximum numbers were lower than those seen in neighbouring Anglian regions, a modest number of grave goods were a feature of a large proportion of burials.

Figure 12 - Figure 18: Online slideshow 
Overall, therefore, the regions that appear as hot spots do so because they had a greater range of grave goods; unfurnished or poorly furnished burials were still common, but were balanced by the inclusion of a notable number of richly furnished burials. It is rare for the levels of furnishing in any site to have had notable skews towards higher numbers. In contrast, the regions that appeared as cold spots had high proportions of unfurnished graves, and lower maximum numbers of objects deposited. Those that lay in between these two extremes vary, between regions with a standard level of 'medium' grave good use, as in the Saxon areas of England, and regions where grave good use fluctuated considerably between sites, as in Kent, eastern Frankia, the Lower Rhine, and the Low Countries. It is not impossible that some of the regions that appear more poorly furnished may have relied more on organic objects in their burials, but this is not currently possible to identify.

\subsection{Types of grave goods}

Perhaps the more important variation is not in the number of objects being placed in graves, but in the types of objects favoured. Many of the different categories of grave goods, especially the more common ones, had a similar distribution to overall numbers. Dress accessories, jewellery, personal accessories, and fittings (Figure 19) were all found most commonly in England or Alamannia, but in lower levels in western Frankia and Burgundy. As fittings are essentially unidentified items within a grave, it is difficult to read too much into their distribution, and it is unsurprising that they follow the overall pattern. There are, however, some interesting variations in dress accessories, jewellery, and personal accessories that can be explored in more detail.

Dress accessories, perhaps the most frequently found type of object in graves (Figure $\underline{20}$ ), were especially common in Alamannia, where it was rare to find a cemetery in which less than $35 \%$ of the graves contained them. They were also especially common in Anglian cemeteries, frequently being found in $50-75 \%$ of graves. Yet they were also present in some cemeteries in much lower numbers, making the Anglian region the one with the most variety in the use of dress accessories. Regions where grave good use overall was low tended towards lower dress accessory use, seen most notably in western Frankia and Burgundy. Their use varied across other regions, making this one of the object types with the most intra-regional variation.

Personal accessories (Figure 21) followed the same overall pattern, but there were far more extreme differences between those regions. Personal accessory deposition was especially high in England, where it was rare to find a cemetery in which less than a quarter of the graves contained personal accessories. In comparison, in western Frankia or Burgundy it was rare to find a cemetery where more than a quarter contained them. Although there was still considerable variation between cemeteries across Alamannia, Bavaria, and the Lower Rhine, personal accessories were generally less common than dress accessories. 


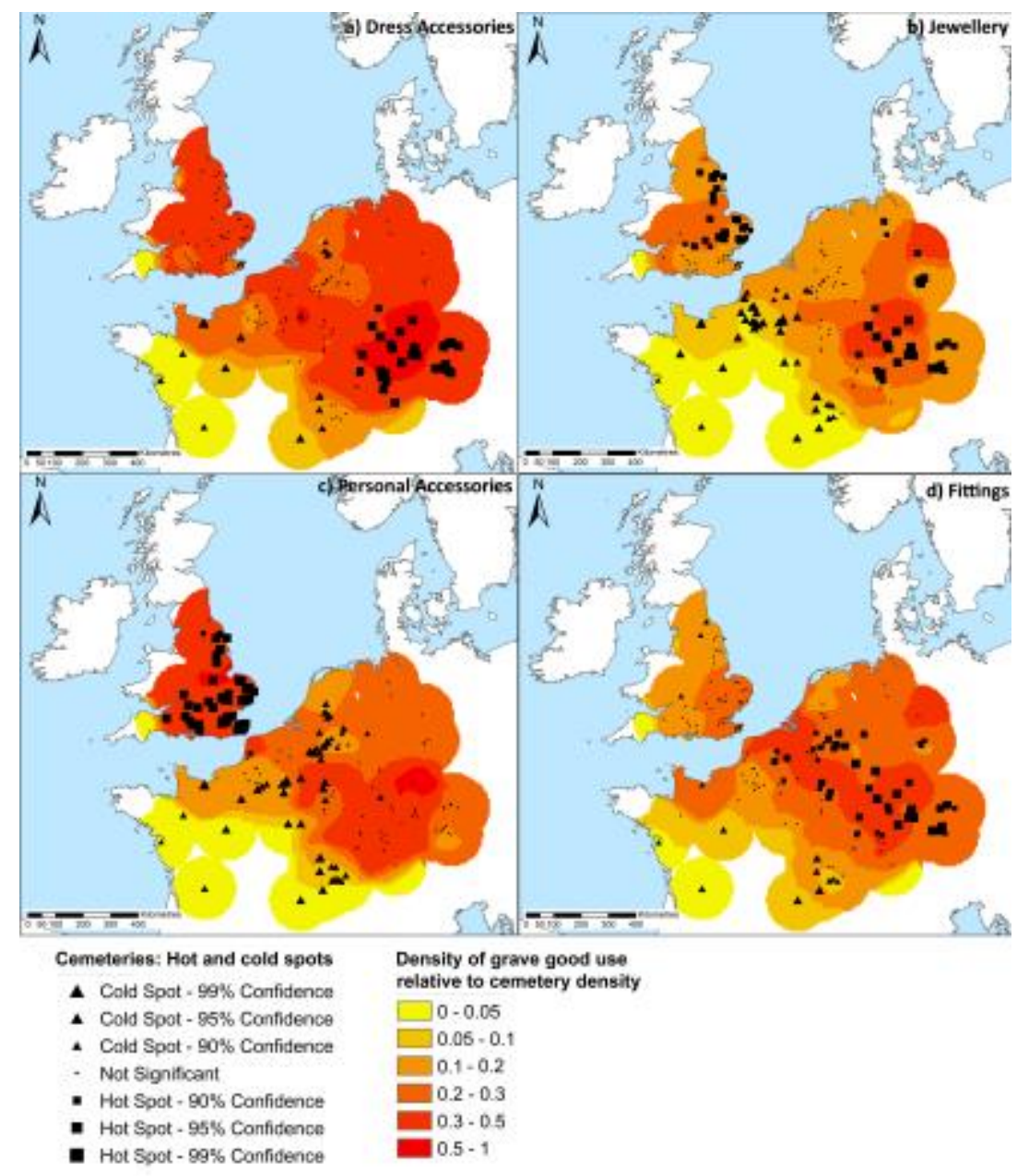

Figure 19: Relative kernel density map of commonly used grave good use in $500 \mathrm{CE}$, showing a similar distribution to overall numbers

Jewellery (Figure 22), being a highly gendered item, was rarely found in more than $50 \%$ of graves in any cemetery. Its use was especially restricted in western Frankia and Burgundy, and while it was more commonly used elsewhere, there was still considerable variation between sites.

Figure 20-Figure 23: Online slideshow

In contrast, the rarer objects were more concentrated in Alamannia, and less commonly found in England, while remaining rare in western Frankia and Burgundy. These rarer objects included cosmetics, amulets, tools, and animal remains (Figure 24). 


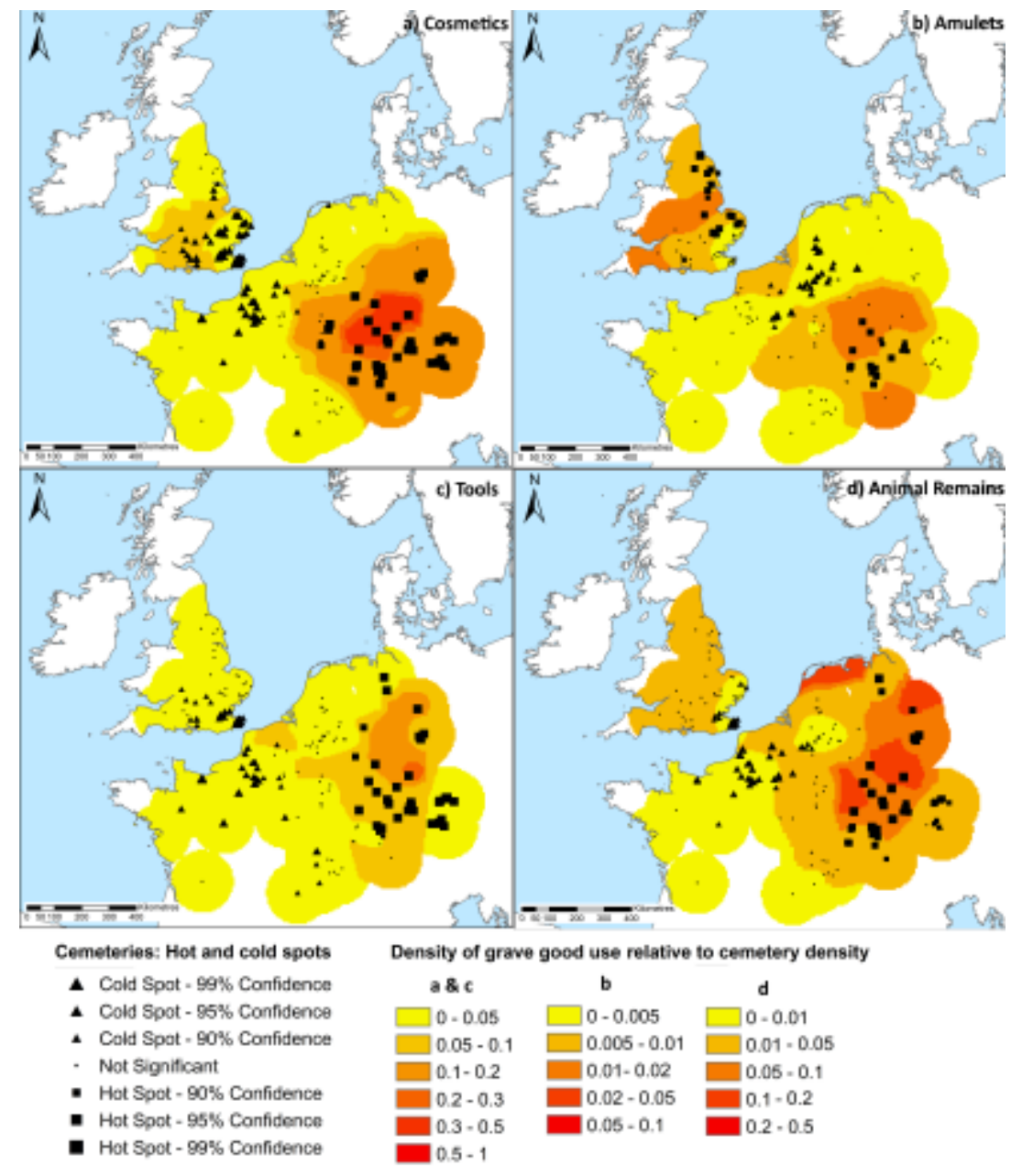

Figure 24: Relative kernel density map of less commonly used grave goods in $500 \mathrm{CE}$, showing a different distribution to overall numbers

Cosmetics (Figure 25) were rarely used in graves in England and along the continental North Sea coast, only occasionally being found in more than $10 \%$ of graves at a site, though they were slightly more common in Saxon regions of England than in Anglian. In Alamannia, their use was more variable, and while there were some cemeteries in which very few graves contained cosmetics, in others they were used far more frequently, over $50 \%$ in some cases. They were found so rarely in Burgundy that this area was excluded from Figure 25.

Neither animal remains (Figure 26) nor tools (Figure 27) were common, and there were many cemeteries from every region where they were not used at all, or in a minute number of graves. There were, however, a few cemeteries across Saxon regions of England, eastern Frankia, and Alamannia, where animal remains were more frequently deposited, and tools were slightly more common in northern Alamannia than they were in other regions.

Figure 25-Figure 32: Online slideshow

Amulets (Figure 28) were one of the least commonly used artefacts, mostly being found in less than $3 \%$ of graves at a site, with only a few exceptions in the Saxon regions of 
England, and in northern Alamannia. Thus, even though this does produce statistically significant hot-spots, the variation is so small that it is difficult to read too much into this.

The most noticeable difference to a standard distribution was seen in the use of vessels (Figure 29). They were found in high concentrations across western Frankia, the Low Countries, and the Lower Rhine, all regions that were cold spots, or at least less densely concentrated for all other categories of grave goods. Vessel use was particularly elevated in the Lower Rhine region, where they were rarely found in less than $35 \%$ of graves. Elsewhere, there was more variety between cemeteries, with sites with high vessel use co-existing alongside those where it was much rarer, but they were notably rare in England, Bavaria, and Burgundy (Figure 30).

There were few areas with notably high concentrations of weapon burials. Burgundy and western Frankia had the lowest concentrations, while there was a hot-spot over Alamannia, but this was not as noticeable as other common object types (Figure 31). This may not be the entire picture, however. When the distribution of weapons is analysed at a smaller geographical scale, their distribution becomes considerably less even, and small clusters with distinct gaps between them can be seen between the Rhine and the Seine, something that has been interpreted as a demonstration of land ownership (Theuws 2009, 309, 311). The extended profile of the Low Countries, as well as the Lower Rhine (Figure 32), confirms that this was an area where there was a great deal of variability between sites in how frequently weapons were used, and the eastern parts of England showed a similar extended profile. Weapons were included in graves at consistent levels between $12 \%$ and $25 \%$ in the other regions of England. Only western Frankia and Burgundy were noticeably lower.

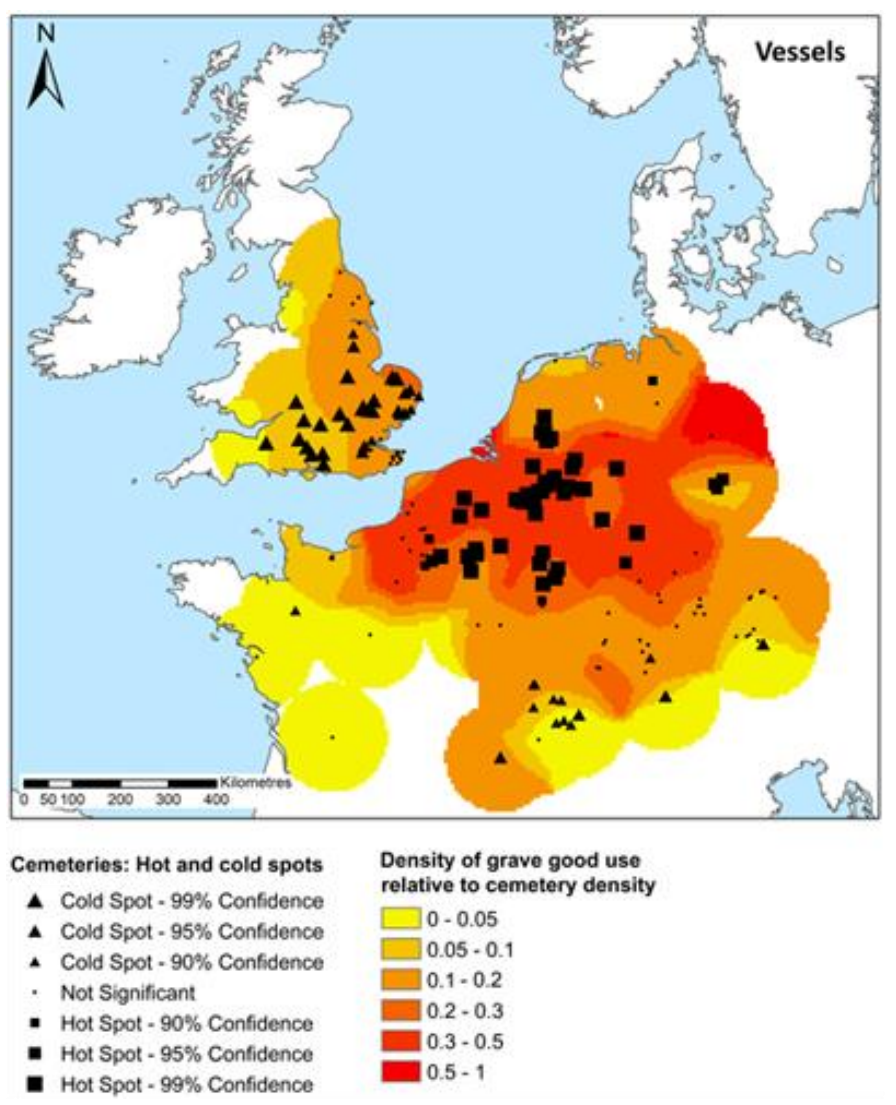

Figure 29: Relative kernel density map of vessel use in $500 \mathrm{CE}$, showing concentrations of high vessel use across western Frankia and the Lower Rhine 


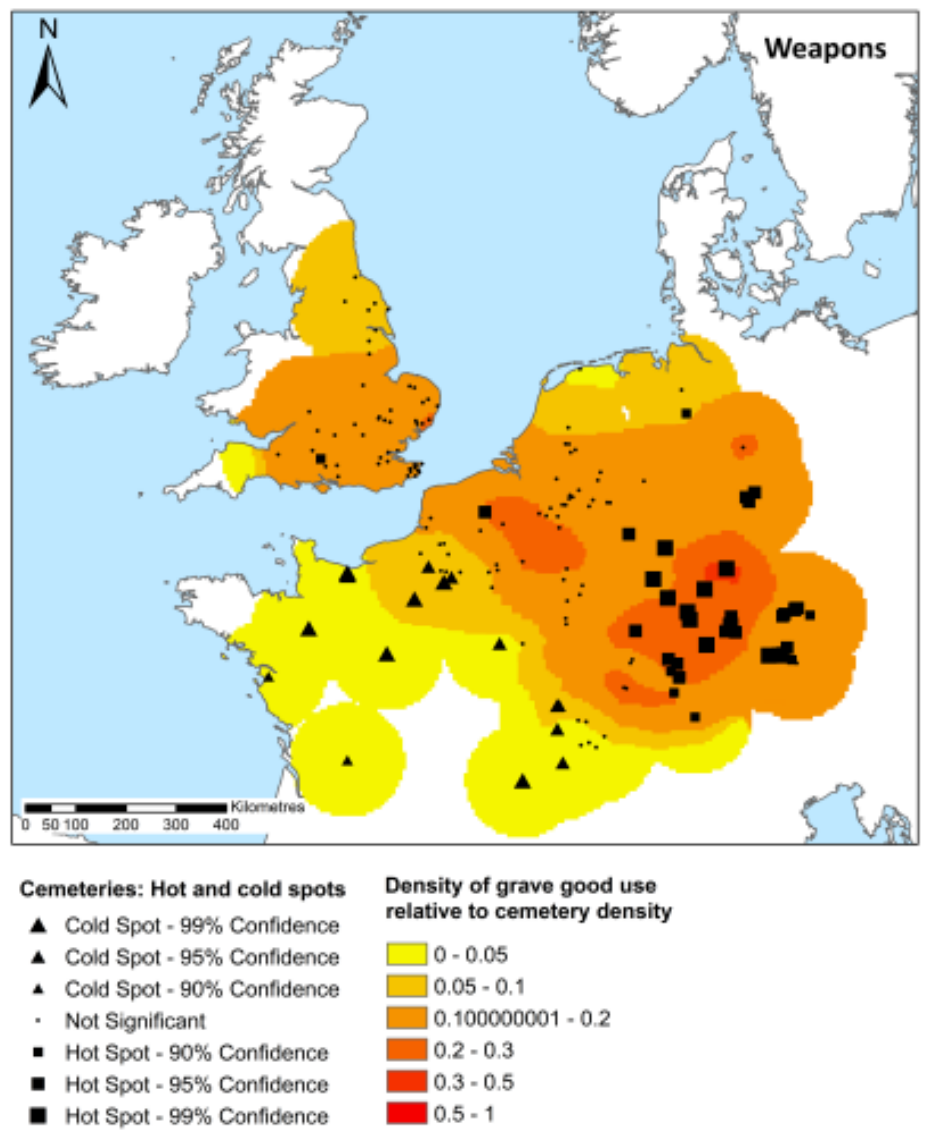

Figure 31: Kernel density maps for weapons at the start of the 6th century

\subsection{Discussion}

To summarise, consistent use of an object type in high quantities was rare in any area; as with overall numbers, where an area appeared as a statistically significant hot-spot, this was usually because cemeteries where that object was common appeared alongside cemeteries where it was rarer. Areas that appeared as neither hot nor cold spots lacked such particularly rich sites but otherwise have a similar profile to the hot spots. There are exceptions to this; dress accessories and personal accessories in northern Alamannia, personal accessories across England, and vessels in the Lower Rhine were all incredibly common, and there were no cemeteries in which they were rarely found. Some objects were rarely used across Europe; in the case of amulets for example, there may have been minor fluctuations, but there was no region where they were commonly deposited in graves.

Western Frankia stood out as a region where almost all object types were rarely found; only dress accessories and vessels were exceptions to that, dress accessory use being comparable to that found elsewhere across Europe, while vessels far exceeded other areas in their frequency of use. Burgundy also stood out as a region where grave good use was predominantly low, with the exception of the one site of Saint Vit. Grave good use was near zero for almost every category, with only dress accessories being used more frequently in some sites. In fact, for several of the violin plots, Burgundy had to be removed, as the cluster around zero was so extreme that it made it difficult to interpret the other regions. 
The predominance of vessels across western Frankia, the Low Countries, and the Lower Rhine is one of the most notable variations identified here. The role that vessels played in the funeral is debated, particularly whether they were deposited as grave goods in their own right, or whether they had secondary significance to their contents (Effros 2002, 85-87). Only occasionally is it clear what the vessel may have contained; vessels are rarely examined for organic residues, and the vast majority are washed, making retrospective study impossible (Effros 2002, 85). Some have been found that held animal remains; there is a copper-alloy vessel from the cemetery of King's Garden Hostel in Cambridge that contained three eel skeletons (Dodwell et al. 2004, 98), but this is a rarity. The inclusion of vessels as food containers may suggest the inclusion of the deceased in funerary feasting (Effros 2002, 80). Other evidence of food provision for the deceased comes from the deposition of whole or partial animal remains, even when there are no signs of butchery present (Effros 2002, 87). As discussed above, the distribution of animal remains is almost the reverse of that of vessels. Animal remains can of course have other significances in the grave rite, other than food, but their differences in distribution could suggest a difference in the form funerary feasting took.

Choices about how many and what types of artefacts to bury with the dead were being made within a range that was locally acceptable. The extent to which those locally acceptable modes of grave good use remained consistent across a region was something that varied; in Saxon regions of England, for example, most cemeteries had similar patterns of grave good use, while regions such as western Frankia and Burgundy appeared more standardised because of the generally low levels of deposition there. Other regions showed more marked variation between sites within them, including eastern Frankia and the Lower Rhine in particular. In almost every instance, however, there was at least one, sometimes more, sites that stood out as being much more restricted in the grave goods used, or in the case of Saint Vit in Burgundy, much less restricted than the norm. This was a period when communities could make choices about the most appropriate way to bury the dead (Theuws $\underline{1999}, 346$ ).

The decisions around what objects to place in a grave were complex. There were broadly defined regional traditions in what objects it was appropriate to place in a grave, and in what quantity. New burials in those areas drew on those regional traditions, so that the cumulative assemblage of grave goods across a cemetery became an expression of community, and lineage (Semple and Brookes 2020, 4). But there was also a great deal of flexibility to adapt these practices, whether consciously or subconsciously. Every burial was unique, a creation of different people in different social circumstances and at a different point in time, with trends being the accumulation of individual decisions made over a cemetery's lifetime (Sayer 2020, 3-4; Williams 2006, $61)$. Some of the variation seen will be due to differences in the identity of the person being buried; we know, for example, that there were clear differences in the types of grave goods suitable for men and women (Halsall 1996, 6; Lucy 1997, 157; Stoodley $1999,29,33-35)$. The fact that jewellery and weapons were rarely found in more than half the graves in a site anywhere in the study regions is testament to that. Even within those identities, however, there was clear flexibility in the types of decisions that could be made. This flexibility may reflect intentional choices in some cases, ranging from a desire to purposefully distinguish the event from past funerals (Williams 2006 , 61 ), to more personal decisions on the part of the mourners about which aspects of the deceased they chose to commemorate (Devlin 2007, 43). However, the variability seen may also have been unintentional. There would have been extended intervals between the burials of individuals of similar social identities, and given that the reproduction of funeral rites relied on the memories and expectations of the community, there was 
always the potential for alterations to be introduced (Sayer 2020, 21). Thus, while burials may appear very different, the intentions behind them may have remained the same (Williams 2006, 61).

There is no simple narrative here, no way of demonstrating that a certain combination of grave goods is indicative of belonging to one region rather than another. Instead, we see a funerary rite that is influenced by the choices others in a community are making, influenced by the choices made in the surrounding communities, influenced by the identity of the deceased, but ultimately something that is highly personal, and based on decisions made in the emotionally charged circumstances surrounding a death. The decisions about whether someone was to be inhumed or cremated, buried in a coffin, or with stone settings, or in a plain, earth-cut grave, were most likely influenced by similar decisions. While regional trends and trends based on identity do exist, this should not be used to obscure the variability within those trends.

\section{Changing Patterns of Cemetery Use}

In order to investigate the way in which grave good use changed in the 7th century and later, it is first necessary to investigate the patterns of use of cemeteries in each region. This is because the statistical tests below are reliant on a rapid turnover of cemeteries for accurate results. But the way in which these patterns varied between regions is in itself interesting, and adds further to our understanding of the way in which grave good use, and funerary practices as a whole, evolved.

The majority of sites in these areas dated to the 6th and 7th centuries, and overall, very few cemeteries could be confidently dated to the 8th century or later. A historic lack of focus on unfurnished burials and cemeteries means that although many later sites have been excavated, they have not been subject to independent dating methods. Instead, they are broadly assumed to be post-8th century, but it remains unclear when they came into use, and how much overlap there may have been with the earlier, predominantly furnished, field cemeteries (Brownlee 2021, 145). No post-8th-century cemeteries could be identified in the Lower Rhine (Figure 38), and many other regions have only one or two clearly dated 8th-century cemeteries. Without that independent dating evidence, such cemeteries could not be included here without risking a circular argument, and the statistical analysis below will therefore focus primarily on any change that occurred within the 6th to early 8th century range. The absence of data from the 8th century onwards does demonstrate, however, that furnished burial was almost entirely abandoned in all regions by the late 8th century.

Most furnished cemeteries were abandoned towards the end of the 7th and start of the 8th century, although the exact date and the suddenness of the abandonment varied. The earliest furnished cemeteries had entirely gone out of use by the mid-8th century across the Lower Rhine (Figure 38), the Low Countries (Figure 39), and western Frankia (Figure 37). In southern Alamannia (Figure 34) most cemeteries went out of use suddenly between 700 and 720 , with very few earlier or later abandonments, while in northern Alamannia (Figure 33) it was a more drawn out process, with the period of abandonment lasting from 680 to 740. In Bavaria (Figure 35), there was more of a pattern of cemeteries continuously going out of and coming into use across the 6th and 
7th centuries, but similarly, few of the earlier, furnished sites continued to be used beyond 720. England (Figure 41, Figure 42, Figure 43) had perhaps the earliest point of abandonment, around 685 CE, following the chronology of Hines and Bayliss (2013). There is evidence for continued use of cemeteries past this point, in the form of radiocarbon or coin dates in a few instances, but even taking that into account, none of these cemeteries lasted beyond the early 8th century.

There were few cemeteries that spanned both the 7th and 8th centuries; less than $3 \%$ of sites in use at the start of the 6th century were still being used at the end of the 8th, and only $6.5 \%$ of sites in use during the 7 th century were still active at the end of the 8 th. It is probable that there was an undetected phase of unfurnished burial at the end of some sites' use, but direct evidence for this was sparse, and it was most likely only brief, so does not fundamentally change this pattern. Burgundy (Figure 36) was the only area where there was any real degree of continuity between the 7th and the 8th century, something that made it appear quite distinct from other regions. There, $35 \%$ of cemeteries in use in the 7th century were still being used at the end of the 8th. Outside Burgundy, the few sites that did span the two centuries were mostly relatively small church cemeteries. The cemetery at Mels in southern Alamannia, for example, contained only 39 burials interred between the mid-6th and late 10th century (Grüninger et al. 1988; Martin 1988); approximately one burial every twelve years. Burial at these sites must therefore have been a rare event, and something not available to the majority of the population. There was in most instances a clear separation between the cemeteries used prior to the 8th century, and those that were used in the 8th century or later.

The lifespans of cemeteries in these regions also varied. Within England, the longestlived cemeteries were found in Anglian regions spanning the 6th and 7th centuries, while the Saxon cemeteries, like the Kentish ones, were shorter lived, with very few lasting from the start of the 6th century to the 7th. In general, though, short-lived cemeteries were a feature of the 7th century. These sites are what would traditionally have been described as 'final phase', and on the whole have lower levels of furnishing than earlier sites. There were a few exceptions; Harford Farm (Penn 2000) in Norfolk still had $72 \%$ of graves furnished, while St Mary's Stadium (Birbeck et al. 2005) and Snell's Corner (Knocker 1956) were also unusually rich. It is clear that these 'final phase' cemeteries are not the only form of burial in the 7th century, and do not represent a transitional phase between large, fully-furnished cemeteries and unfurnished church cemeteries, as was once suggested (e.g. Hyslop 1963), but coincide with them both. Across Alamannia, and to some extent Bavaria, there was a mixture of long-lived and short-lived cemeteries, with many of the short-lived cemeteries dating to the 7th century. This should not be confused with a 'final-phase' similar to that identified in England, as many of these sites were still comparatively well furnished. The cemeteries in the Lower Rhine area were unusually long lived, with none of them lasting for less than a century. This causes problems with the statistical methods employed in the following section; these methods depend on a relatively rapid turnover of cemeteries to be able to illustrate change over time. When so many cemeteries were in use for such a long period of time, this region will appear to have more static practice than it did in reality.

Figure 33-Figure 43: Online slideshow 


\section{Changing Grave Good Use Over Time \\ 5.1 Overall levels of furnishing}

The areas that saw the highest overall levels of grave good use also saw the strongest declines. Across the entire region of Alamannia, there was a statistically significant decrease in the number of grave goods used over time. The cemeteries in northern Alamannia were, on average, richer than those of southern Alamannia, but in both instances, the only poorly furnished cemeteries were those that went out of use in the late 7th century or later. There were still richer cemeteries that continued in use until the early 8th century, but these were joined by new, more poorly furnished ones. At the same time, both regions saw a similar increase in the proportion of unfurnished burials in their cemeteries (Figure 44, Figure 45). In contrast, the decline in grave good use across Bavarian sites was far weaker and cemeteries were consistently furnished at around the same levels during the 7th and 8th centuries. However, Bavaria had the disadvantage that the richer cemeteries (see Figure 8) had less accurate dating available, and so have been excluded from this statistical analysis (igure 46).

There was also a clear decrease in the use of grave goods within the main period of furnished burial in both Anglian (Figure 47) and Saxon regions (Figure 48), accompanied by a rise in the proportions of unfurnished graves in those cemeteries. The decline within Anglian cemeteries was one of the clearest of all regions; almost all of the cemeteries that went out of use in 660 or later had lower average numbers of grave goods than earlier cemeteries. This was also true within Saxon cemeteries, although there was less of a clear difference there between the early and late sites; rather, more poorly furnished sites were used alongside existing, richer ones, in a similar pattern to that observed in Alamannia. These trends were some of the strongest and the clearest in the entire dataset. This does not necessarily mean that there was a more direct correlation between grave good use and date in England than on the continent, however. As discussed above, the differences in chronological schemes used in England and the rest of the continent affect the way trends were evident in those areas. The apparent stronger trends in the English sample may just be a product of dating methodologies, therefore, rather than a specific difference in the way grave good use changed. 

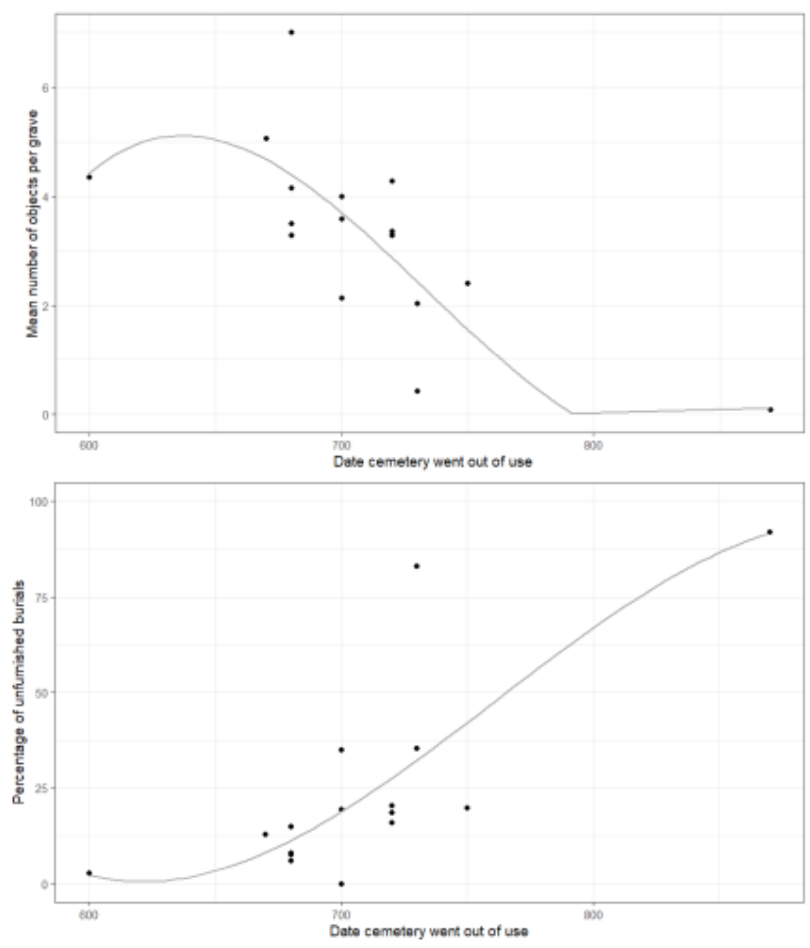

Figure 44: Trends in numbers of objects and unfurnished burials in northern Alamannia. Polynomial trendlines order 3 
Table 2: Results of Spearman's rho and Kendall's tau-b for the correlation of number of grave goods and unfurnished burials with the date a cemetery went out of use in northern Alamannia. Statistically significant trends highlighted in yellow in yellow

Overall trend

Correlation co-efficient
P-value

$<2.2 \mathrm{e}-16$

$<2.2 \mathrm{e}-16$
Trend during period of furnished burial

Correlation co-efficient

P-value
Unfurnished burial 1.046e-11 

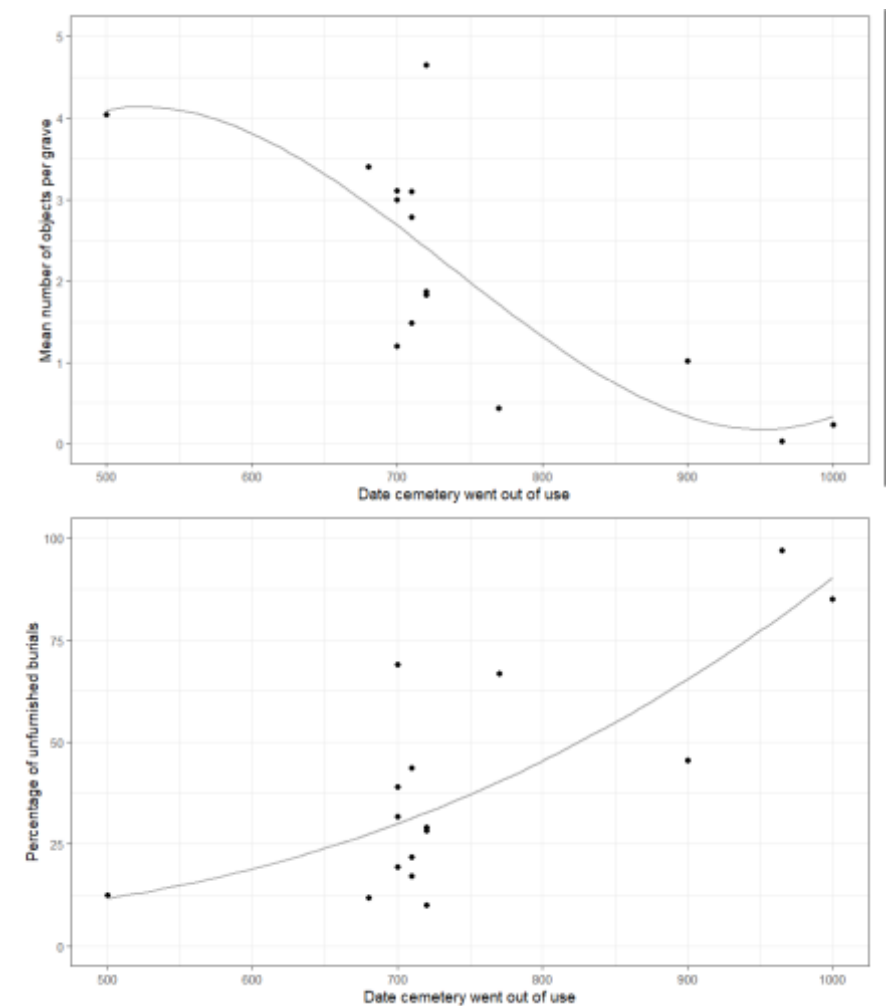

Figure 45: Trends in numbers of objects and unfurnished burials in southern Alamannia. Polynomial trendlines order 3 
Table 3: Results of Spearman's rho and Kendall's tau-b for the correlation of number of grave goods and unfurnished burials with the date a cemetery went out of use in southern Alamannia. Statistically significant trends highlighted in yellow

Overall trend

Correlation co-efficient
P-value

$<2.2 \mathrm{e}-16$

$<2.2 \mathrm{e}-16$
Trend during period of furnished burial

Correlation co-efficient

P-value
Number of objects

0.212

$-0.251$

$<2.2 \mathrm{e}-16$

Unfurnished burial
$-0.325$ 

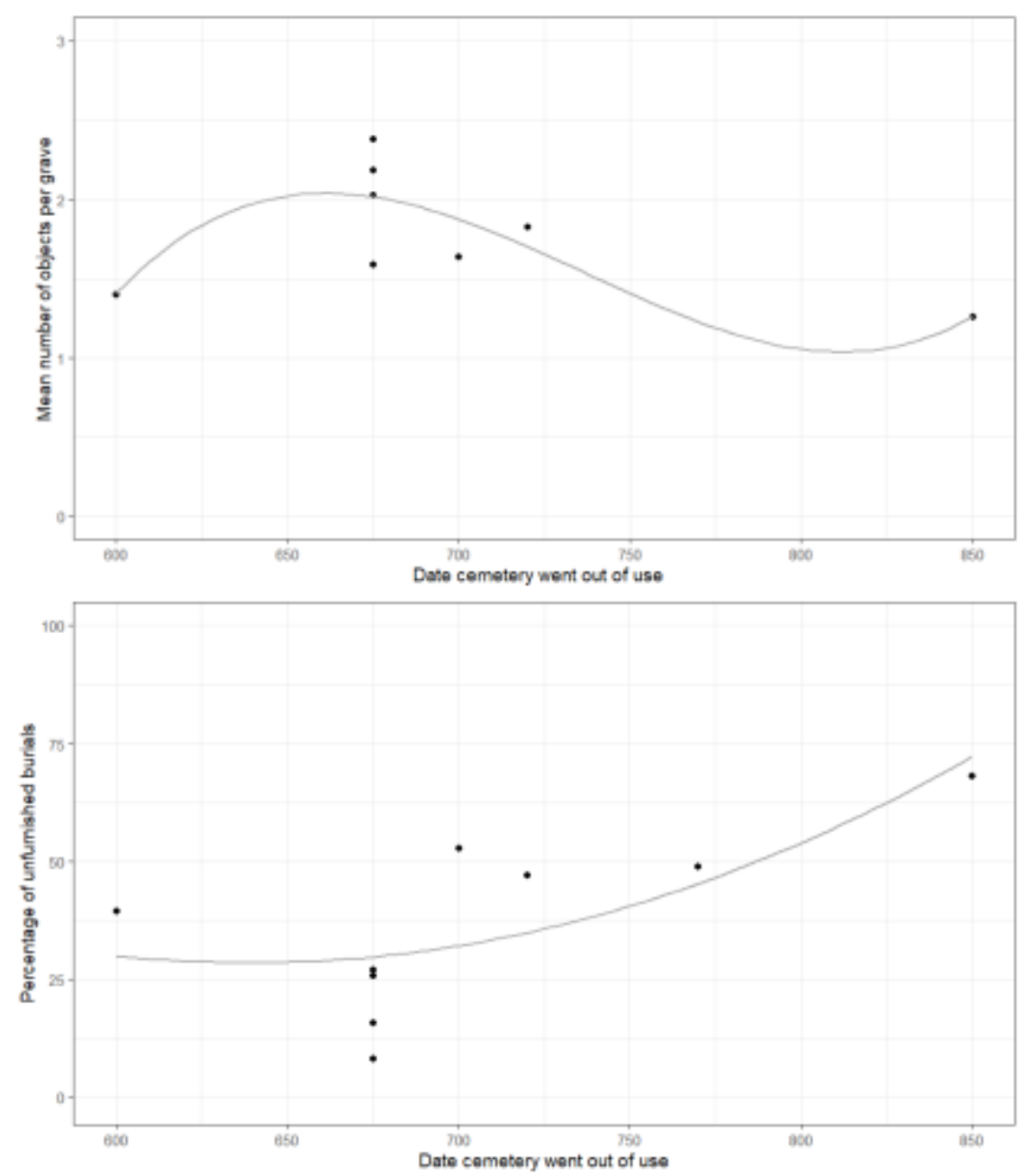

Figure 46: Trends in numbers of objects and unfurnished burials in Bavaria. Polynomial trendline order 3 for numbers of objects, order 2 for unfurnished graves 
Table 4: Results of Spearman's rho and Kendall's tau-b for the correlation of number of grave goods and unfurnished burials with the date a cemetery went out of use in Bavaria. Statistically significant trends highlighted in yellow

\section{Overall trend}

Correlation co-efficient

$-0.051$

0.104
P-value

0.00826

Unfurnished burial 2.662e-08 

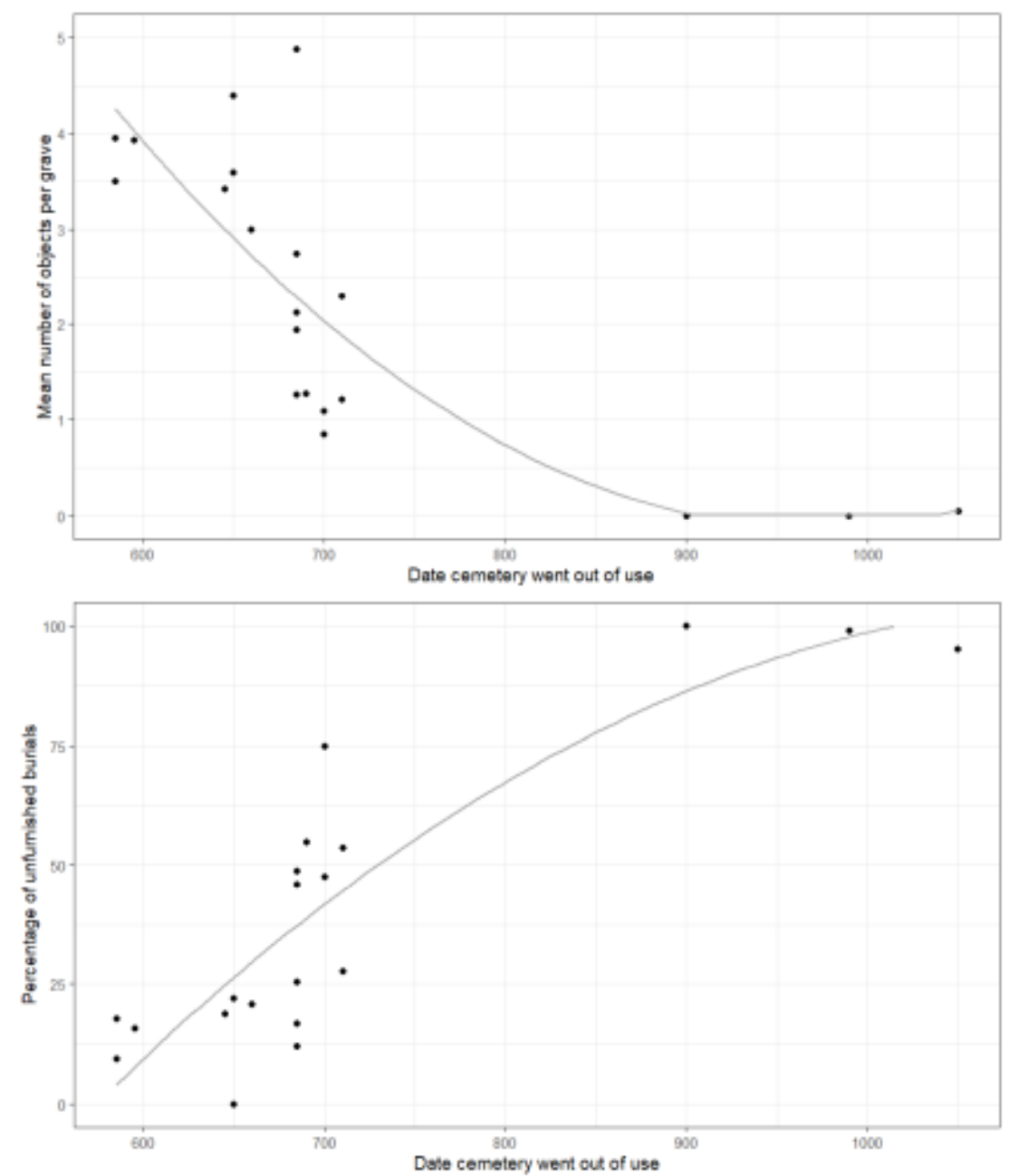

Figure 47: Trends in numbers of objects and unfurnished burials in Anglian regions. Polynomial trendlines, order 2 
Table 5: Results of Spearman's rho and Kendall's tau-b for the correlation of number of grave goods and unfurnished burials with the date a cemetery went out of use in Anglian regions. Statistically significant trends highlighted in yellow

Overall trend

Correlation co-efficient

$-0.608$

0.521
Trend during period of furnished burial

P-value

Correlation co-efficient

P-value

Number of objects

$<2.2 \mathrm{e}-16$

$-0.330$

$<2.2 \mathrm{e}-16$

Unfurnished burial

$<2.2 \mathrm{e}-16$

0.234

$<2.2 \mathrm{e}-16$ 

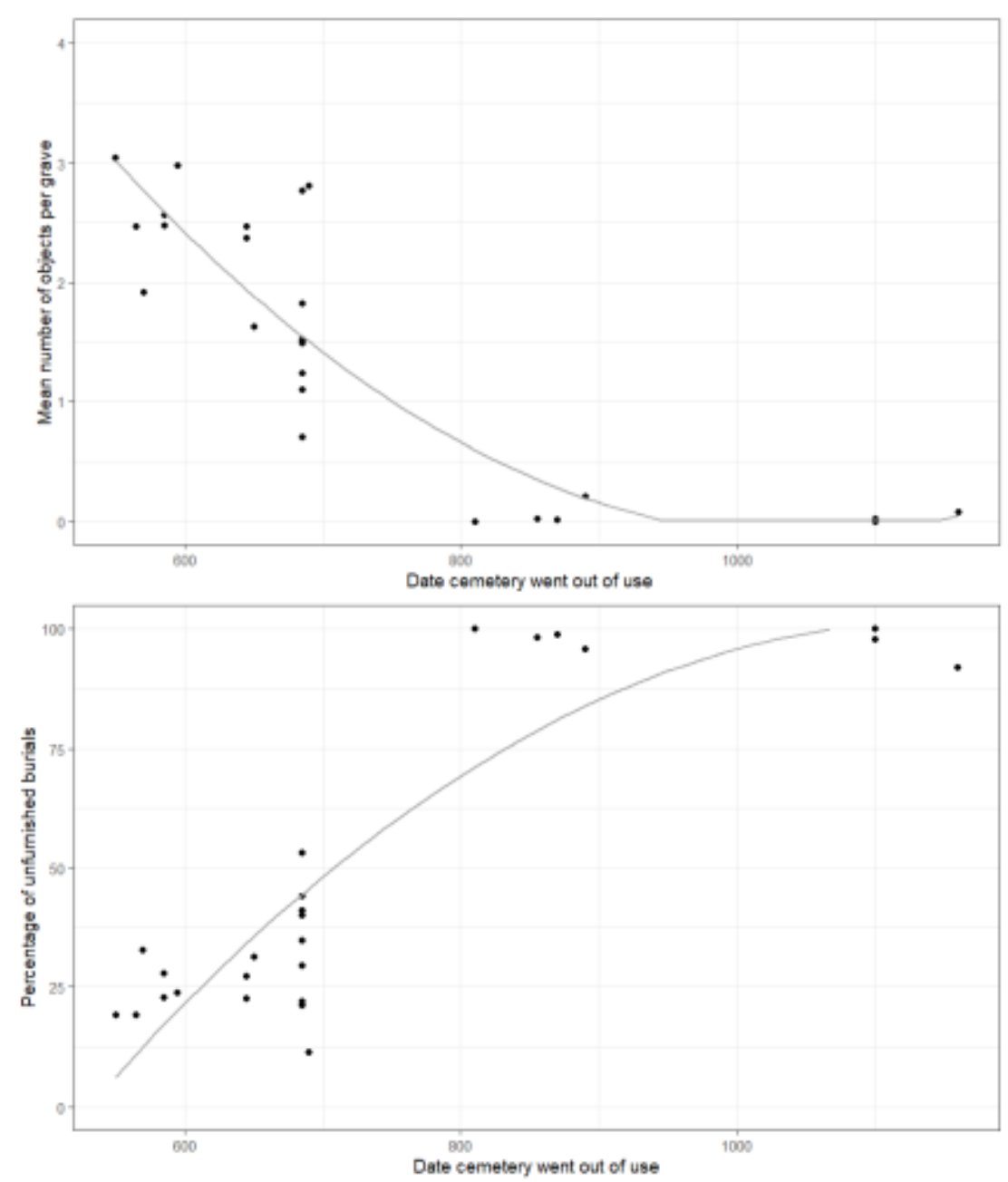

Figure 48: Trends in numbers of objects and unfurnished burials in Saxon regions. Polynomial trendline order 2 
Table 6: Results of Spearman's rho and Kendall's tau-b for the correlation of number of grave goods and unfurnished burials with the date a cemetery went out of use in Saxon regions. Statistically significant trends highlighted in yellow

Overall trend

Correlation co-efficient
P-value

$<2.2 \mathrm{e}-16$

$<2.2 \mathrm{e}-16$
Trend during period of furnished burial

Correlation co-efficient

P-value

Number of objects

0.451

0.085 2.184e-09

0.0002584

Burgundy was one of the regions with the lowest levels of grave good use, but despite this, it still saw a clear decrease in the numbers of objects deposited in graves over time, and an increase in the proportions of unfurnished graves (Figure 49). This is the case even if Saint Vit, an early, anomalously richly furnished site, is excluded from the analysis. 

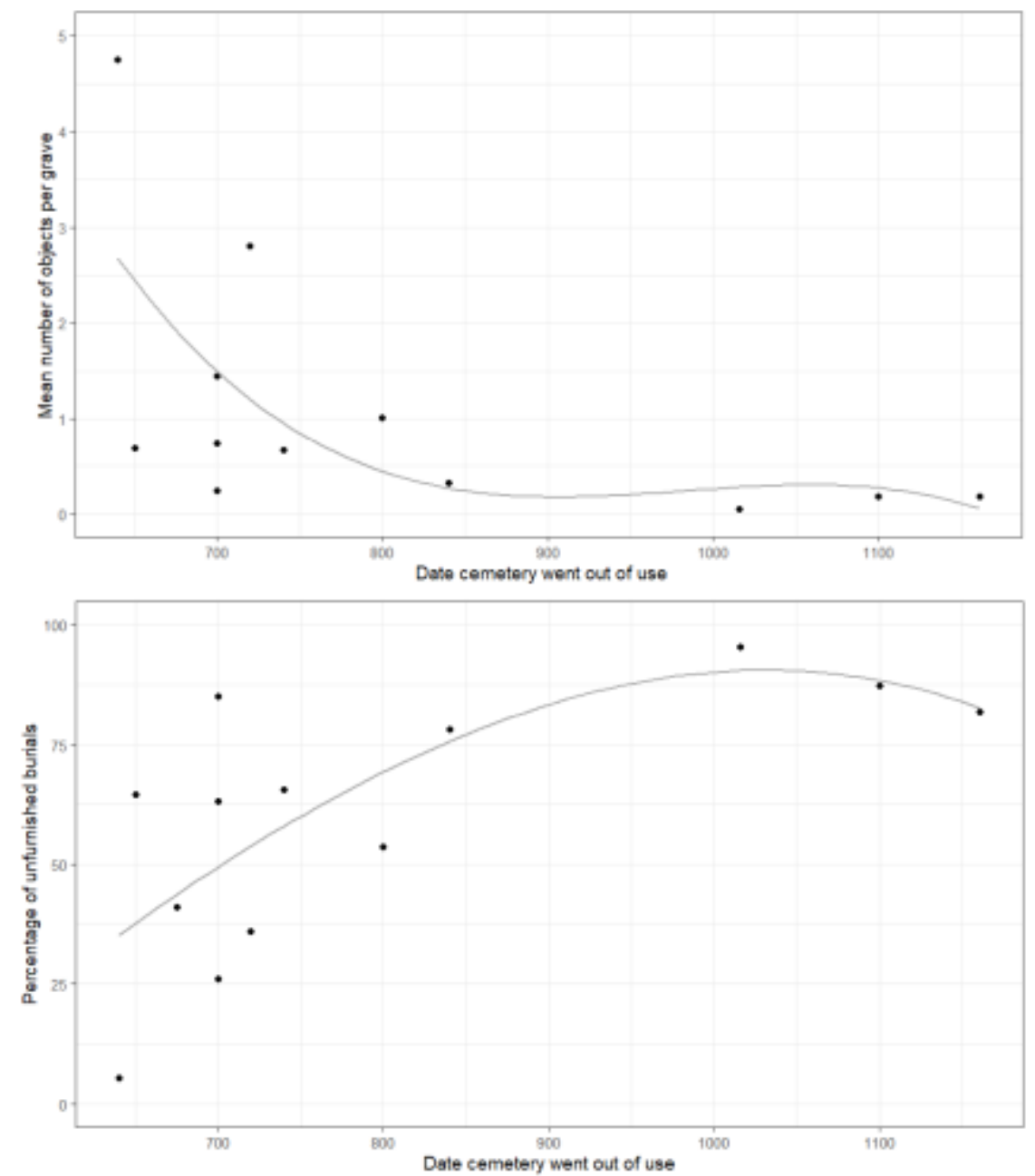

Figure 49: Trends in numbers of objects and unfurnished burials in Burgundy. Polynomial trendline order 3 for the mean number of objects, order 2 for unfurnished graves 
Table 7: Results of Spearman's rho and Kendall's tau-b for the correlation of number of grave goods and unfurnished burials with the date a cemetery went out of use in Burgundy. Statistically significant trends highlighted in yellow

Overall trend

Correlation co-efficient

$-0.325$

0.267
Trend during period of furnished burial

P-value

Correlation co-efficient

P-value

Number of objects

$<2.2 \mathrm{e}-16$

$-0.273$

$<2.2 \mathrm{e}-16$

Unfurnished burial

$<2.2 \mathrm{e}-16$

0.220 
Other areas where there was a statistically significant decrease in grave good deposition include the Lower Rhine region (Figure 50), and eastern Frankia (Figure 51), although neither of these had as strong a trend as that seen in the Alamannian and Anglo-Saxon regions. This may be partially due to the longevity of cemeteries in the Lower Rhine region. Here, there were no cemeteries that went out of use during the 6th century, and both poorly and richly furnished cemeteries co-existed alongside each other throughout the 7th and early 8th centuries.

The variability in the level of furnishing between sites is more likely to explain the weaker trends in eastern Frankia. The later cemeteries did tend to use fewer grave goods than earlier ones, but there were many exceptions to this. The cemetery of Arlon (Roosens and Alenus-Leclerf 1965), for example, contained no unfurnished graves, and had an average of over six objects per grave, yet went out of use around 700 . Although there was a tendency towards lower deposition in this area, it was not a clear trend.

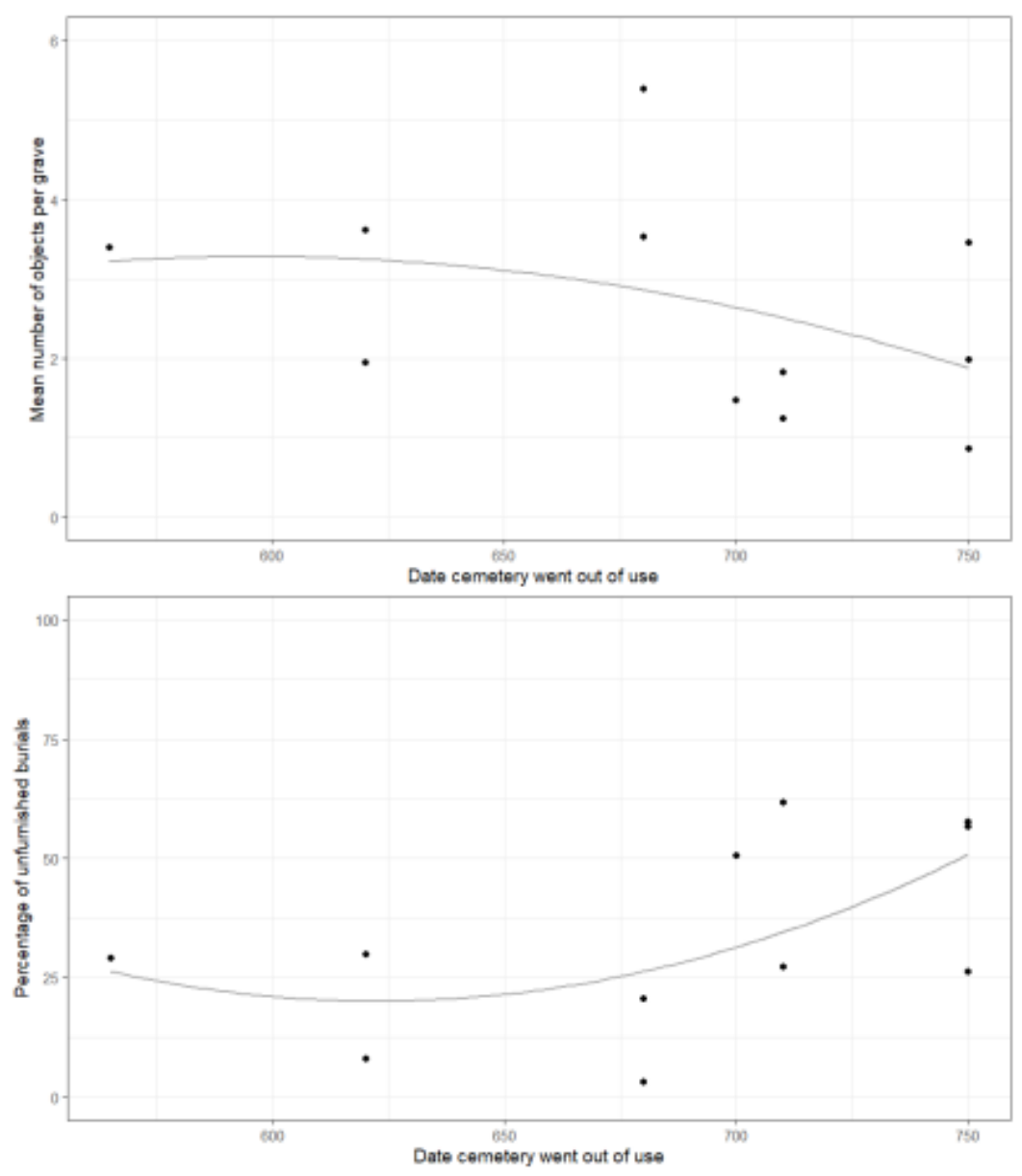

Figure 50: Trends in numbers of objects and unfurnished burials in the Lower Rhine. Polynomial trendlines order 2 
Table 8: Results of Spearman's rho and Kendall's tau-b for the correlation of number of grave goods and unfurnished burials with the date a cemetery went out of use in the Lower Rhine. Statistically significant trends highlighted in yellow

\section{Overall trend}

Correlation co-efficient

0.138
P-value

$<2.2 \mathrm{e}-16$

4.195e-12

Unfurnished burial 

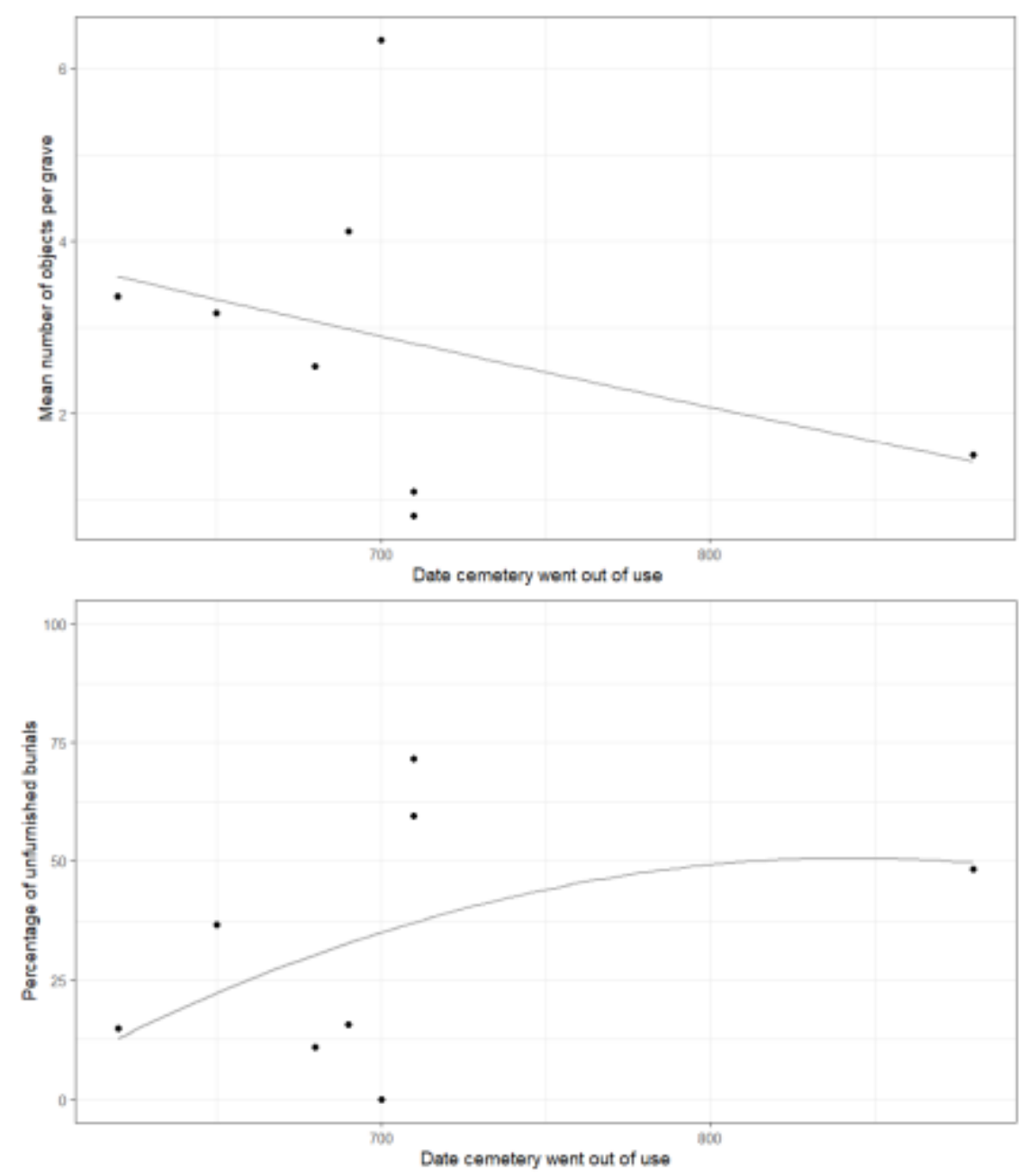

Figure 51: Trends in numbers of objects and unfurnished burials in eastern Frankia. Polynomial trendlines order 2 
Table 9: Results of Spearman's rho and Kendall's tau-b for the correlation of number of grave goods and unfurnished burials with the date a cemetery went out of use in eastern Frankia. Statistically significant trends highlighted in yellow

Overall trend

Correlation co-efficient
P-value

0.0001296

2.106e-07 
All of the areas discussed thus far have shown some level of decline, as might be expected, but there are also regions where this was not the case. In western Frankia (Figure 52), Kent (Figure 53), and the Low Countries (Figure 54), there was no appreciable decrease in grave good use. In Kent, the average number of objects found in graves was similar to the levels found in Saxon regions but, unlike the Saxon regions, there was neither a tendency towards a lower number of objects over time nor a significant increase in the number of unfurnished graves. In western Frankia, there was a slight increase in the number of unfurnished burials, but again, this was a very weak trend, and there was no change in the numbers of objects used. This pattern of change appears most similar to Bavaria, where there was also little change in overall numbers, but an increase in the use of unfurnished burial. Grave good use and numbers of unfurnished burials were entirely static in the Low Countries. This is not to say that grave good use in these regions continued any later than in others; the fact that there were no furnished cemeteries post-700 shows that there was a transition from furnished to unfurnished burial that was contemporary with the rest of Europe. However, the lack of an appreciable decrease prior to this point suggests that the change occurred much more suddenly here than it did elsewhere, with a rapid abandonment towards the end of the 7th century, rather than the gradual decline seen elsewhere.
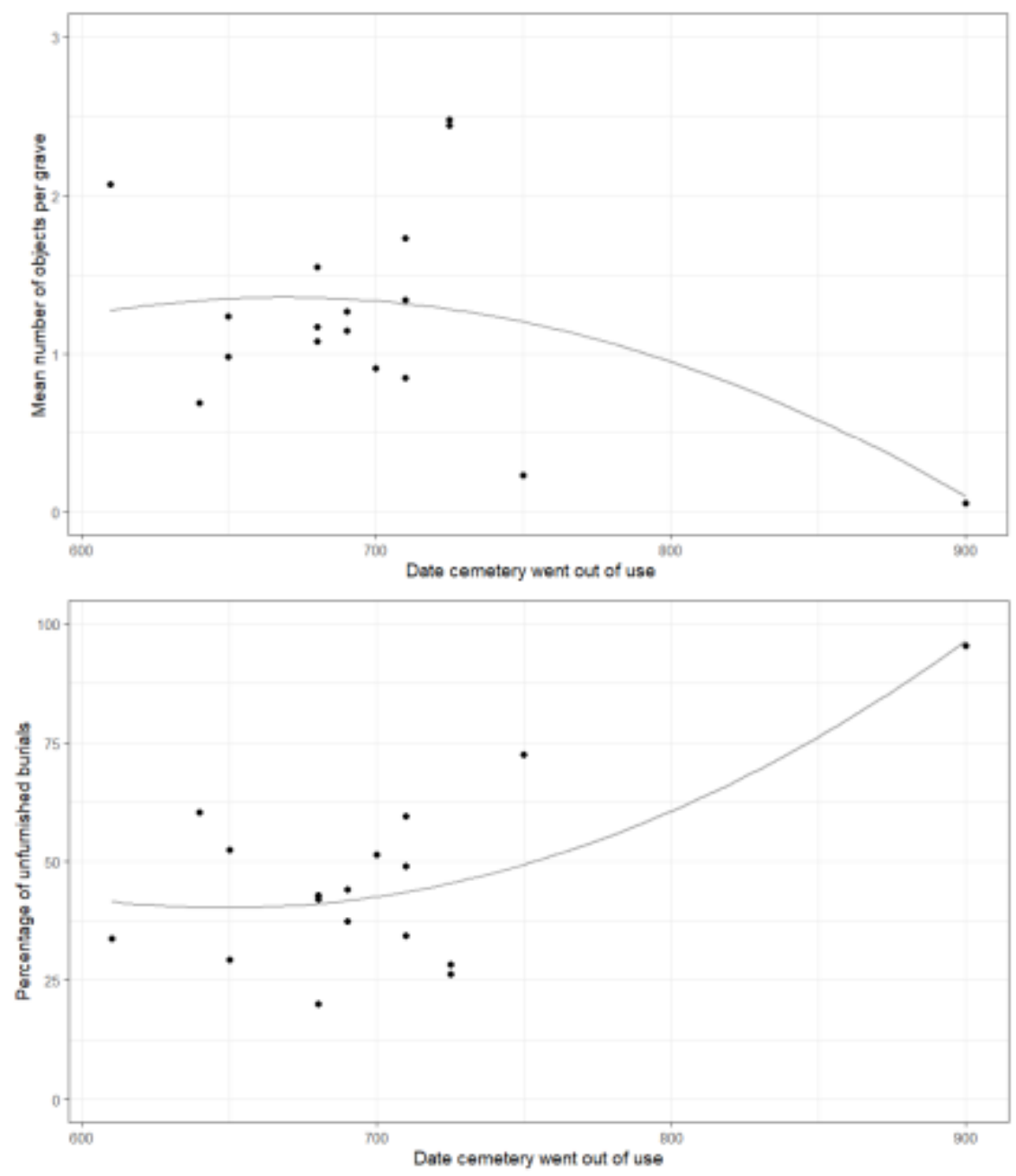

Figure 52: Trends in numbers of objects and unfurnished burials in western Frankia. Polynomial trendlines, order 2 for mean number of objects, order 3 for unfurnished graves 
Table 10: Results of Spearman's rho and Kendall's tau-b for the correlation of number of grave goods and unfurnished burials with the date a cemetery went out of use in western Frankia. Statistically significant trends highlighted in yellow

Overall trend

Correlation co-efficient

$-0.022$

0.054
Trend during period of furnished burial

P-value

Correlation co-efficient

P-value

Number of objects

0.225

0.001

0.973

Unfurnished burial

0.0006382
0.0006382 

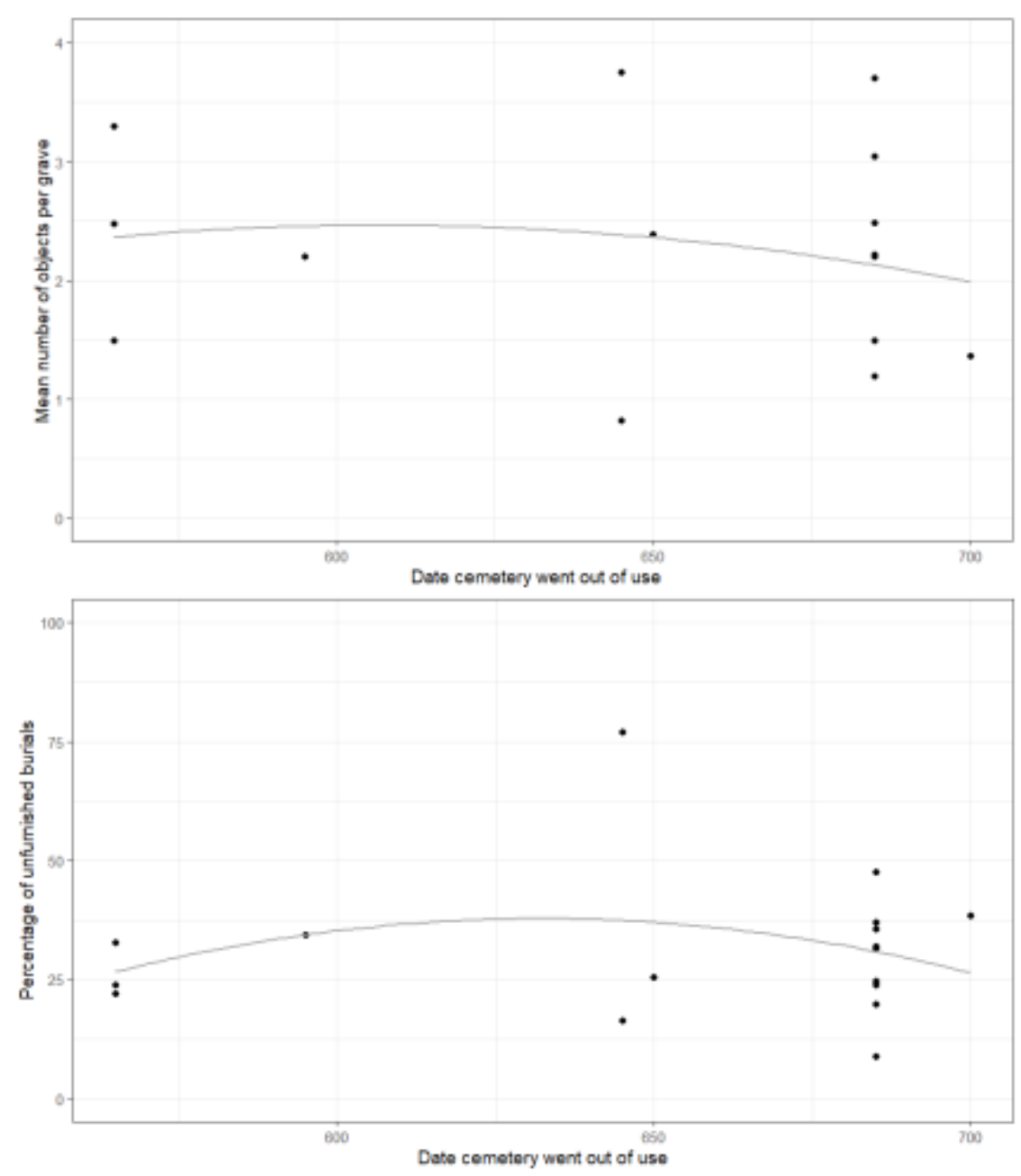

Figure 53: Trends in numbers of objects and unfurnished burials in Kent. Polynomial trendlines order 2 
Table 11: Results of Spearman's rho and Kendall's tau-b for the correlation of number of grave goods and unfurnished burials with the date a cemetery went out of use in Kent. No statistically significant trends found.

Overall trend

Correlation co-efficient

P-value

Number of objects

Unfurnished burial

0.8866 

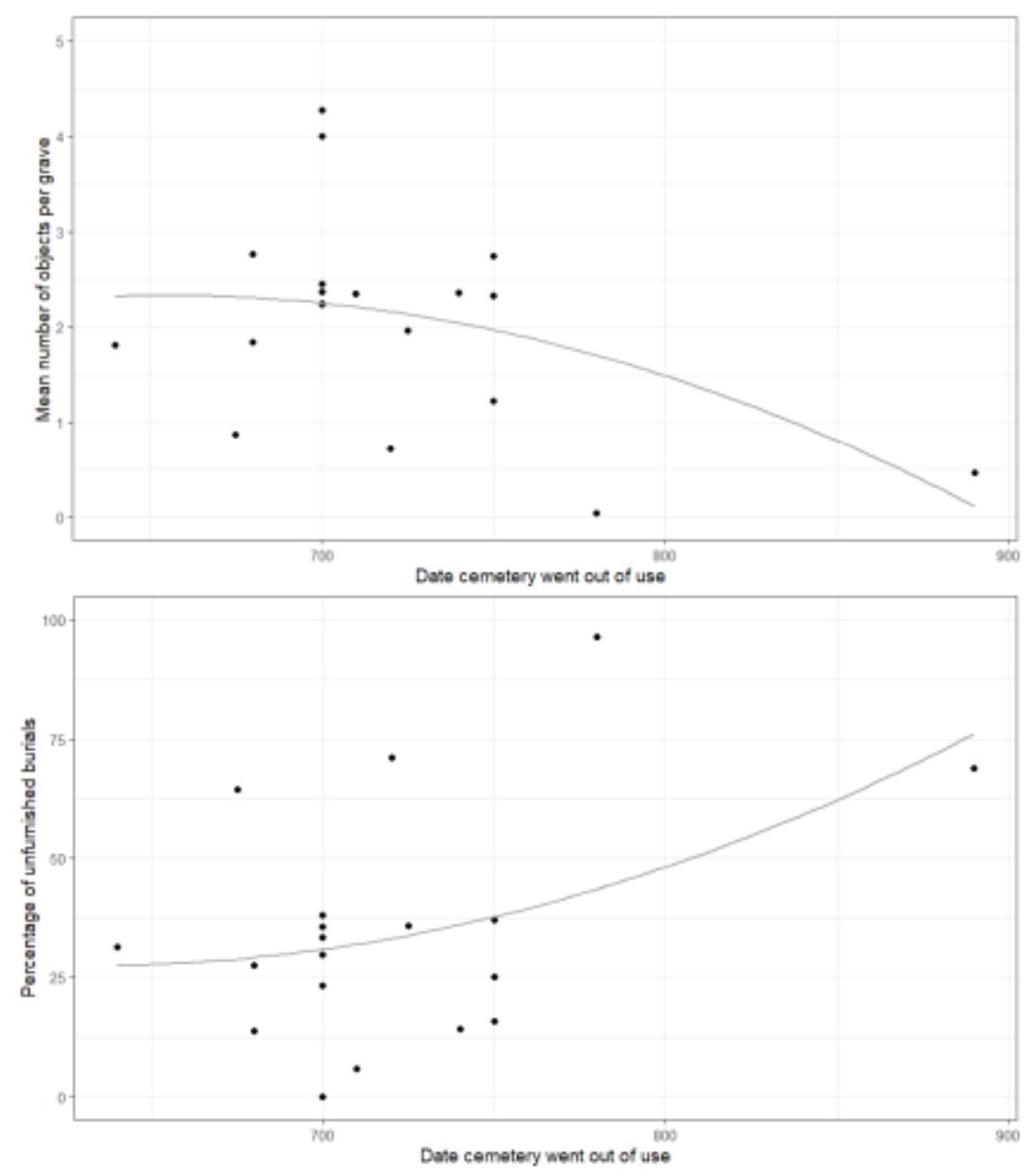

Figure 54: Trends in numbers of objects and unfurnished burials in the Low Countries. Polynomial trendlines order 2 
Table 12: Results of Spearman's rho and Kendall's tau-b for the correlation of number of grave goods and unfurnished burials with the date a cemetery went out of use in the Low Countries. No statistically significant trends found.

Overall trend

Correlation co-efficient

Number of objects

Unfurnished burial

$$
-0.013
$$

Trend during period of furnished burial

P-value

Correlation co-efficient

P-value

0.5628

0.031

0.1865

0.5779

$-0.024$
0.2503 


\section{$\underline{5.2 \text { Types of grave goods }}$}

Within these overall trends, there was variation in the way that different types of objects changed, from a decline across all categories, to the decrease being seen in a few types only, with some objects in fact becoming more commonly deposited over time.

Within Alamannia, most types of grave good showed statistically significant decreases. There were some differences between the north and south; in the northern region (Figure 55), only personal accessories and animal remains were deposited at consistent levels across the 6th and 7th centuries, while everything else declined. Animal remains were a relatively rare category of object, but personal accessories were one of the most common types found in Alamannic graves, and remained so across the entire period of furnished burial. In the southern part of Alamannia (Figure 56), the trends were slightly different; personal accessories did become less commonly deposited over time, along with every object category except jewellery and amulets. Again, amulets were only rarely used in graves; that they showed no change over time is therefore unsurprising, but the continued use of more common objects like vessels suggests real differences in the significance that these objects had in the funerary rituals of those different areas.

Within the Anglian cemeteries, there were clear statistically significant decreases in most types of object, though the rarer objects - cosmetics, tools, amulets, coins, and animal remains - showed no such change (Figure 57), and the decrease in personal accessories was very slight. The changes seen in Saxon regions were smaller than those in Anglian regions, with both tools and amulets showing a statistically significant increase over the course of the 6th and 7th centuries (Figure 58). The majority of other object types decreased, with the exception of coins and, again, personal accessories.

In Bavaria (Figure 59), there were far fewer changes in the types of objects used in graves. Rarer objects such as animal remains, coins, cosmetics, and tools, remained at low levels of use, but more common objects, such as personal accessories and vessels, also showed no significant decrease. The only statistically significant changes that did occur were a decrease in dress accessories, and this was miniscule compared to the changes seen in Alamannia. Amulets in fact became more commonly deposited over time.

Almost all the different categories of object showed some degree of change over the period of furnished burial in the Lower Rhine region, the only exceptions being the rarest types, amulets and coins (Figure 60). In no instances were any of the trends in decreasing numbers particularly strong, and, as with overall numbers, cemeteries with high use of these objects co-existed alongside cemeteries where they were rarely used. In all aspects, the Lower Rhine was a region of funerary variability.

In eastern Frankia (Figure 61), the changes in the types of grave good were again varied. Dress accessories, vessels, weapons, and animal remains all decreased in the frequency with which they were used. All other categories saw no statistically significant changes in this region.

Burgundy saw decreases in all artefact types, the only region where this was the case, although many of the trends were relatively weak (Figure 62). In many cases, the pattern was skewed by the cemetery of Saint Vit, which had considerably higher levels of grave good use than the other Burgundian cemeteries. This was especially true of vessels, 
which were found in $72 \%$ of graves at Saint Vit; the next most common figure was $18 \%$. As with overall numbers, excluding Saint Vit did not change these trends, only weaken them, and therefore we can be confident that there was a greater tendency towards unfurnished burial over time in Burgundy.

The regions where there was no change in overall levels of furnishing were not entirely static in their grave good use. In Kent (Figure 63), many different object types saw no clear decline in their use, but dress accessories, fittings, and amulets all decreased in the frequency with which they were placed in graves. In western Frankia (Figure 64) and the Low Countries (Figure 65), most object categories remained consistently used, and the main changes were in fact statistically significant increases; of personal accessories and vessels in western Frankia, and jewellery, personal accessories, vessels and coins in the Low Countries. The only decrease seen was in the use of weapons in the Low Countries, although none of these correlations were particularly strong. Vessels were initially found in very high levels in the graves of these regions, suggesting that their presence was highly important for the funerary rite there, and remained so throughout the entire period of furnished burial.

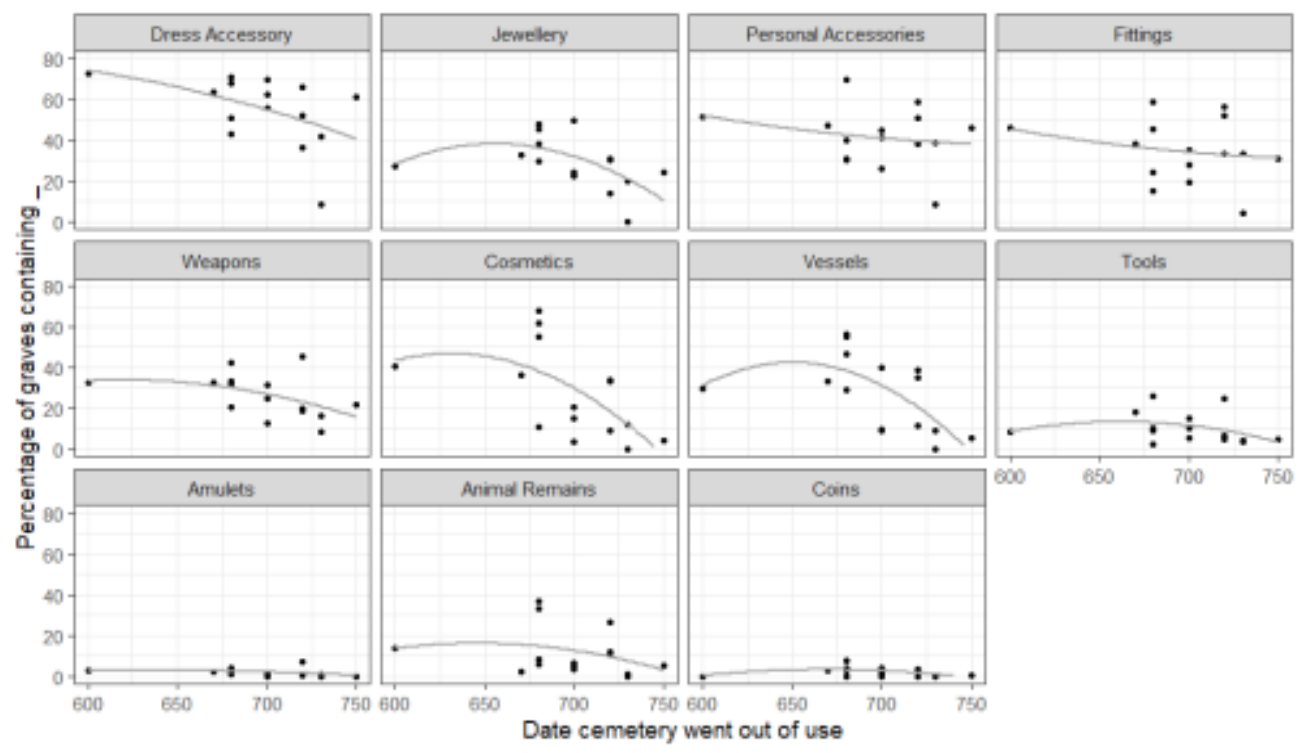

Figure 55: Changes in different types of grave goods in northern Alamannia 
Table 13: Results of Kendall's tau-b for the correlation of presence/absence of object types in graves, with the date a cemetery went out of use in northern Alamannia. Statistically significant trends highlighted in yellow

\section{Change over the period of furnished burial $(\mathrm{N}=\mathbf{2 6 2 2})$}

Type

Dress accessories

Jewellery

Personal accessories

Fittings

Weapons

Cosmetics

Vessels

Tools

Amulets
$T_{b}$ Value

$-0.083$

$-0.095$

0.006

0.071

$-0.098$

$-0.125$

$-0.152$

$-0.037$

$-0.068$
P-Value

3.757e-06

1.394e-07

0.7492

7.104e-05

$4.258 \mathrm{e}-08$

3.809e-12

$<2.2 \mathrm{e}-16$

0.03719

0.0001559 
Animal remains

Coins
0.013

$-0.050$
0.482

0.005134 


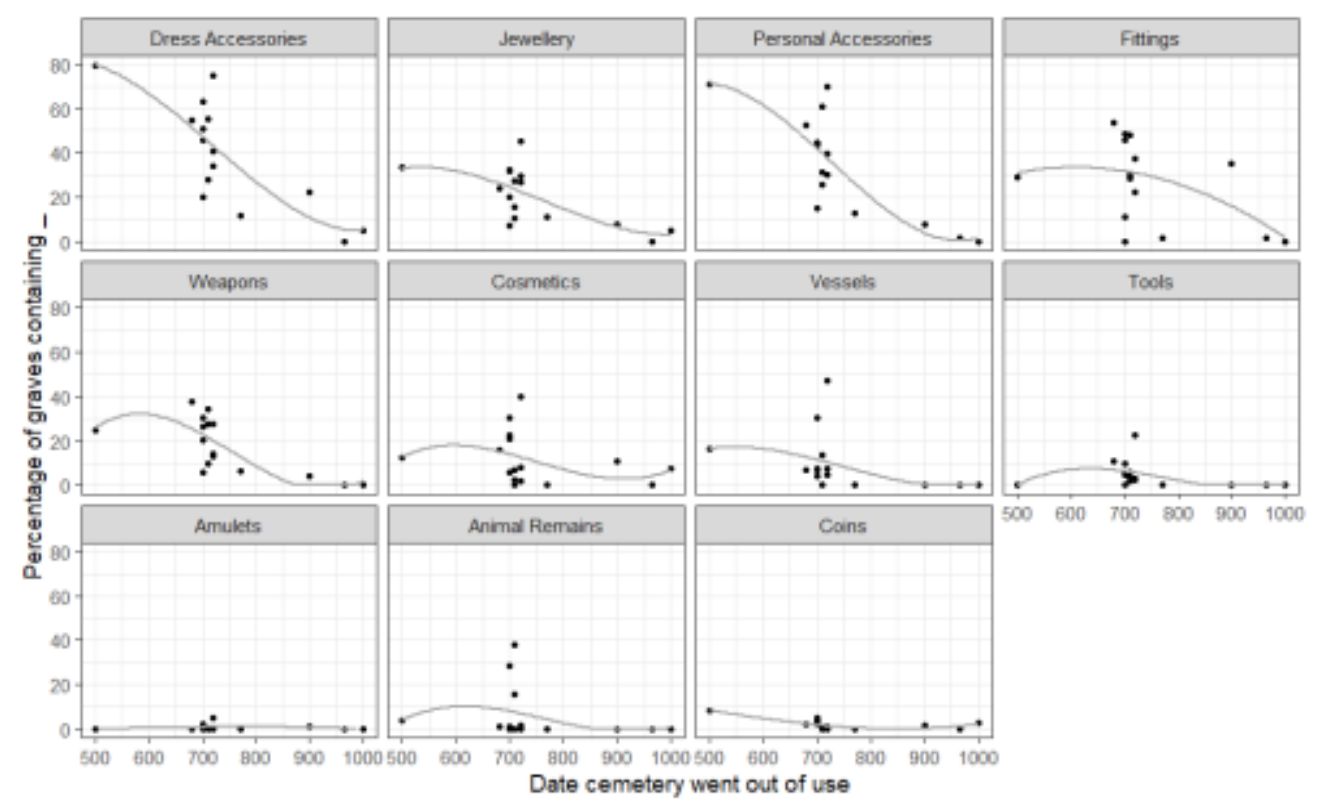

Figure 56: Changes in different types of grave goods in southern Alamannia

Table 14: Results of Kendall's tau-b for the correlation of presence/absence of object types in graves, with the date a cemetery went out of use in southern Alamannia. Statistically significant trends highlighted in yellow

\section{Change over the period of furnished burial $(\mathrm{N}=1727)$}

Type

Dress accessories

Jewellery
$T_{b}$ Value

$-0.191$

$-0.034$
P-Value

$<2.2 \mathrm{e}-16$

0.1128 
Personal accessories

Fittings

Weapons

Cosmetics

Vessels

Tools

Amulets

Animal remains

Coins 3.348e-14

1.557e-09

2.677e-13

$5.518 \mathrm{e}-11$

0.007723

2.752e-05

0.7961

0.001293

0.000428 


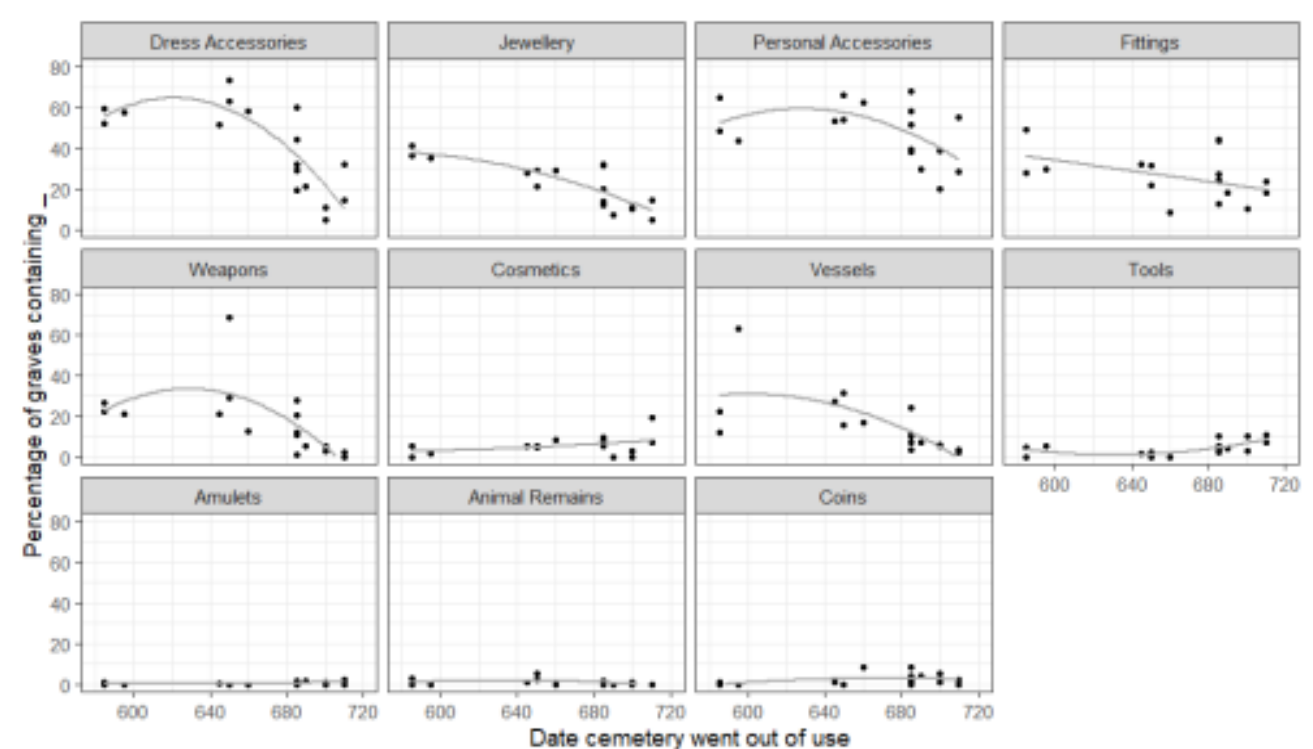

Figure 57: Changes in different types of grave goods in Anglian regions

Table 15: Results of Kendall's tau-b for the correlation of presence/absence of object types in graves, with the date a cemetery went out of use in Anglian regions. Statistically significant trends highlighted in yellow.

Change over the period of furnished burial $(\mathrm{N}=1393)$

Type

Dress accessories

Jewellery
$T_{b}$ Value

$-0.266$

$-0.176$
P-Value

$<2.2 \mathrm{e}-16$

$1.272 \mathrm{e}-13$ 
Personal accessories

Fittings

Weapons

Cosmetics

Vessels

Tools

Amulets

Animal remains

Coins
$-0.090$

$-0.119$

$-0.188$

0.035

$-0.199$

0.044

0.017

$-0.033$

0.046
0.0001513

5.735e-07

$2.285 \mathrm{e}-15$

0.1378

$<2.2 \mathrm{e}-16$

0.06265

0.4825

0.1659

0.05279 


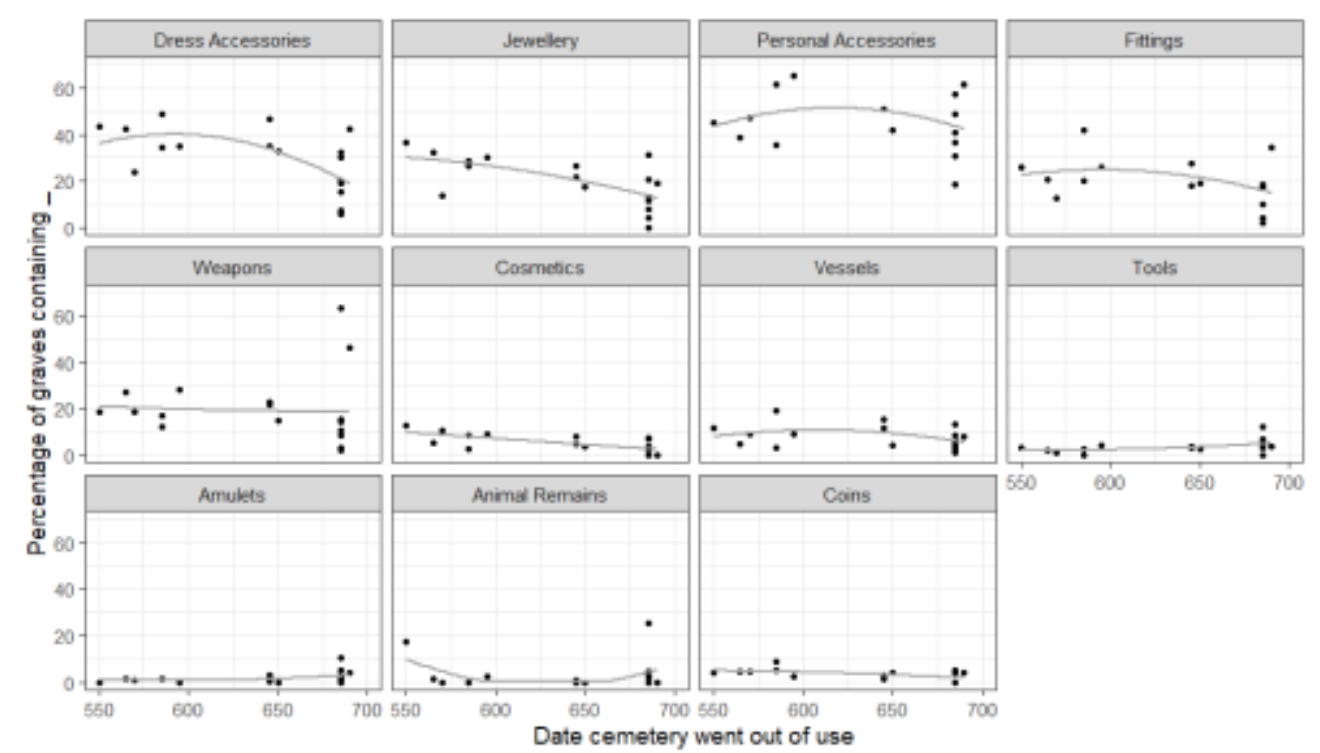

Figure 58: Changes in different types of grave goods in Saxon regions of England

Table 16: Results of Kendall's tau-b for the correlation of presence/absence of object types in graves, with the date a cemetery went out of use in Saxon regions of England. Statistically significant trends highlighted in yellow

Type

Dress accessories

Jewellery
Change over the period of furnished burial $(\mathrm{N}=1799)$

$T_{b}$ Value

P-Value

$-0.129$

8.801e-10

$-0.087$

3.257e-05 
Personal accessories

Fittings

Weapons

Cosmetics

Vessels

Tools

Amulets

Animal remains

Coins
$-0.006$

$-0.094$

$-0.063$

$-0.067$

$-0.049$

0.064

0.049

0.089

$-0.038$
0.7584

$6.708 \mathrm{e}-06$

0.002645

0.001502

0.01893

0.002289

0.01932

$2.233 e-05$

0.06833 


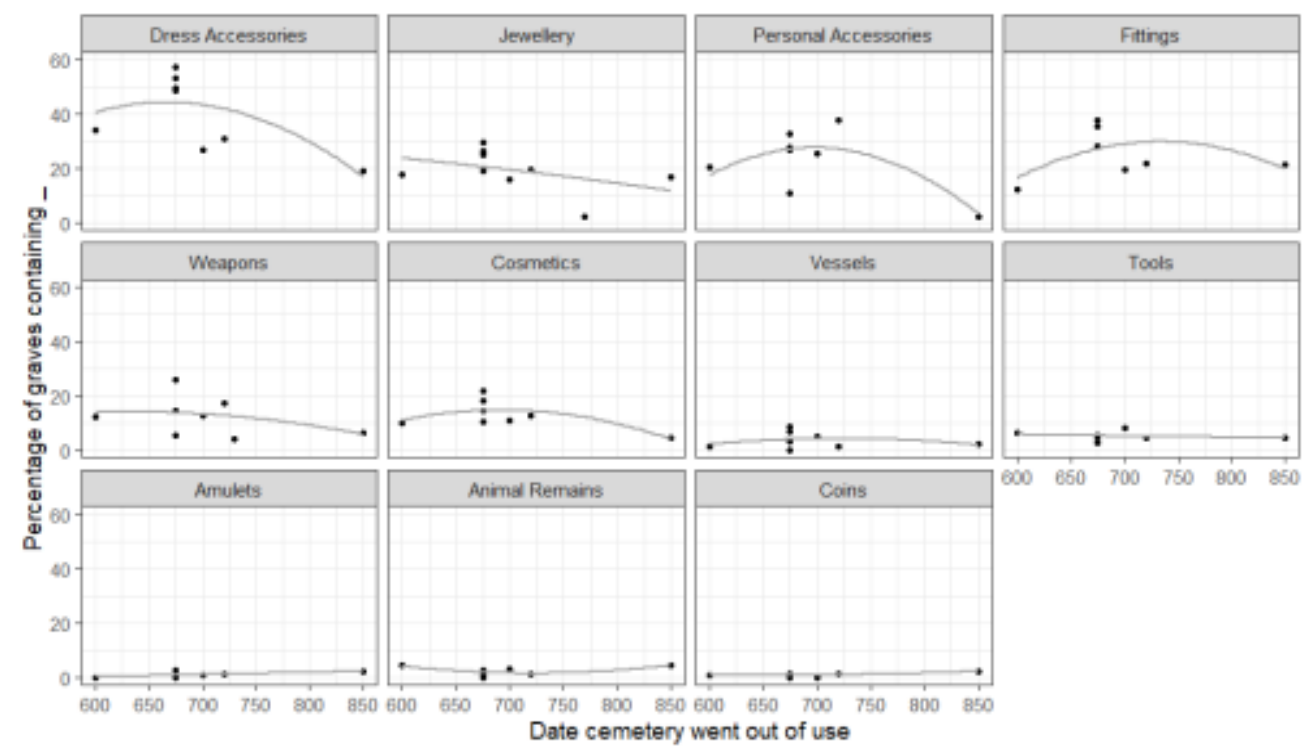

Figure 59: Changes in different types of grave goods in Bavaria

Table 17: Results of Kendall's tau-b for the correlation of presence/absence of object types in graves, with the date a cemetery went out of use in Bavaria. Statistically significant trends highlighted in yellow

\section{Change over the period of unfurnished burial $(\mathrm{N}=\mathbf{2 7 1 2})$}

\section{Type}

Dress accessories

Jewellery

\section{$T_{b}$ Value}

$-0.077$

$-0.024$
P-Value

3.531e-05

0.1993 
Personal accessories

Fittings

Weapons

Cosmetics

Vessels

Tools

Amulets

Animal remains

Coins
0.006

0.007

$-0.004$

$-0.005$

0.002

0.005

0.044

$-0.009$

$-0.002$
0.7451

0.7056

0.829

0.8015

0.9291

0.7708

0.01894

0.6159

0.9301 


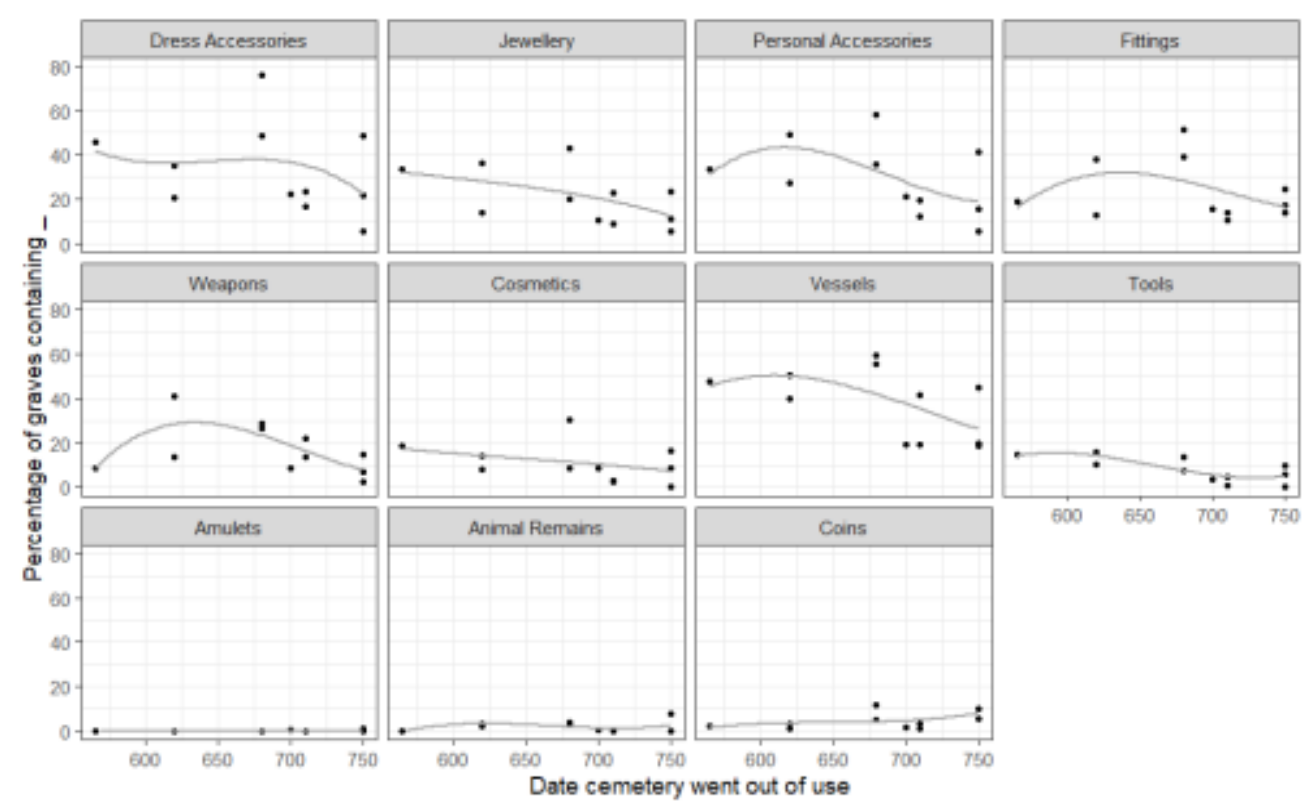

Figure 60: Changes in different types of grave goods in the Lower Rhine

Table 18: Results of Kendall's tau-b for the correlation of presence/absence of object types in graves, with the date a cemetery went out of use in the Lower Rhine. Statistically significant trends highlighted in yellow

\section{Change over the period of furnished burial $(\mathrm{N}=\mathbf{2 1 3 8})$}

Type

Dress accessories

Jewellery
$T_{b}$ Value

$-0.131$

$-0.066$

\section{P-Value}

4.846e-11

0.0009225 
Personal accessories

Fittings

Weapons

Cosmetics

Vessels

Tools

Amulets

Animal remains

Coins
$-0.149$

$-0.142$

$-0.056$

$-0.116$

$-0.104$

$-0.094$

0.012

$-0.055$

0.032
$9.1 \mathrm{e}-14$

$1.202 \mathrm{e}-12$

0.00511

5.188e-09

$1.621 \mathrm{e}-07$

2.589e-06

0.5565

0.006069

0.114 


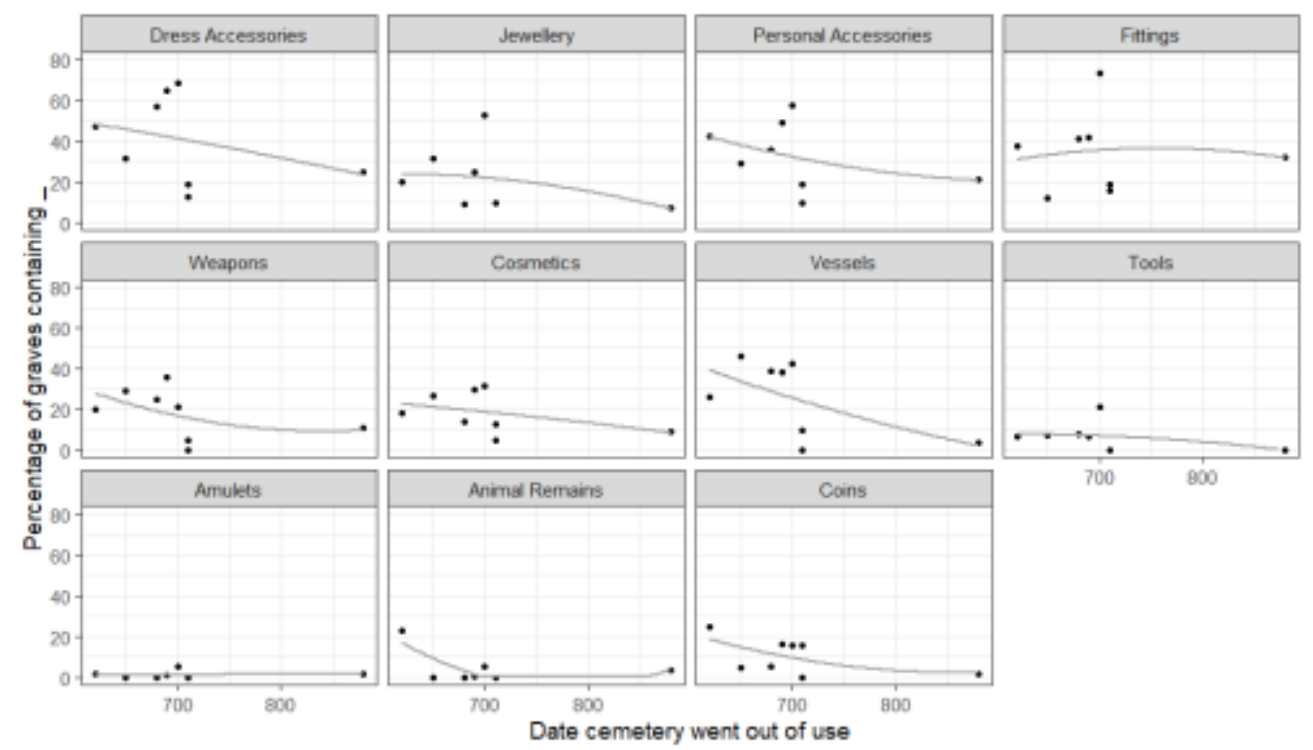

Figure 61: Changes in different types of grave goods in eastern Frankia

Table 19: Results of Kendall's tau-b for the correlation of presence/absence of object types in graves, with the date a cemetery went out of use in eastern Frankia. Statistically significant trends highlighted in yellow

Change over the period of furnished burial $(\mathrm{N}=578)$

Type

Dress accessories

Jewellery
$\mathrm{T}_{\mathrm{b}}$ Value

$-0.088$

$-0.017$

0.642 
Personal accessories

Fittings

Weapons

Cosmetics

Vessels

Tools

Amulets

Animal remains

Coins
$-0.051$

$-0.004$

$-0.074$

$-0.021$

$-0.161$

$-0.061$

0.027

$-0.162$

$-0.034$
0.1763

0.9135

0.04896

0.5825

1.738e-05

0.1054

0.4679

1.547e-05

0.3607 


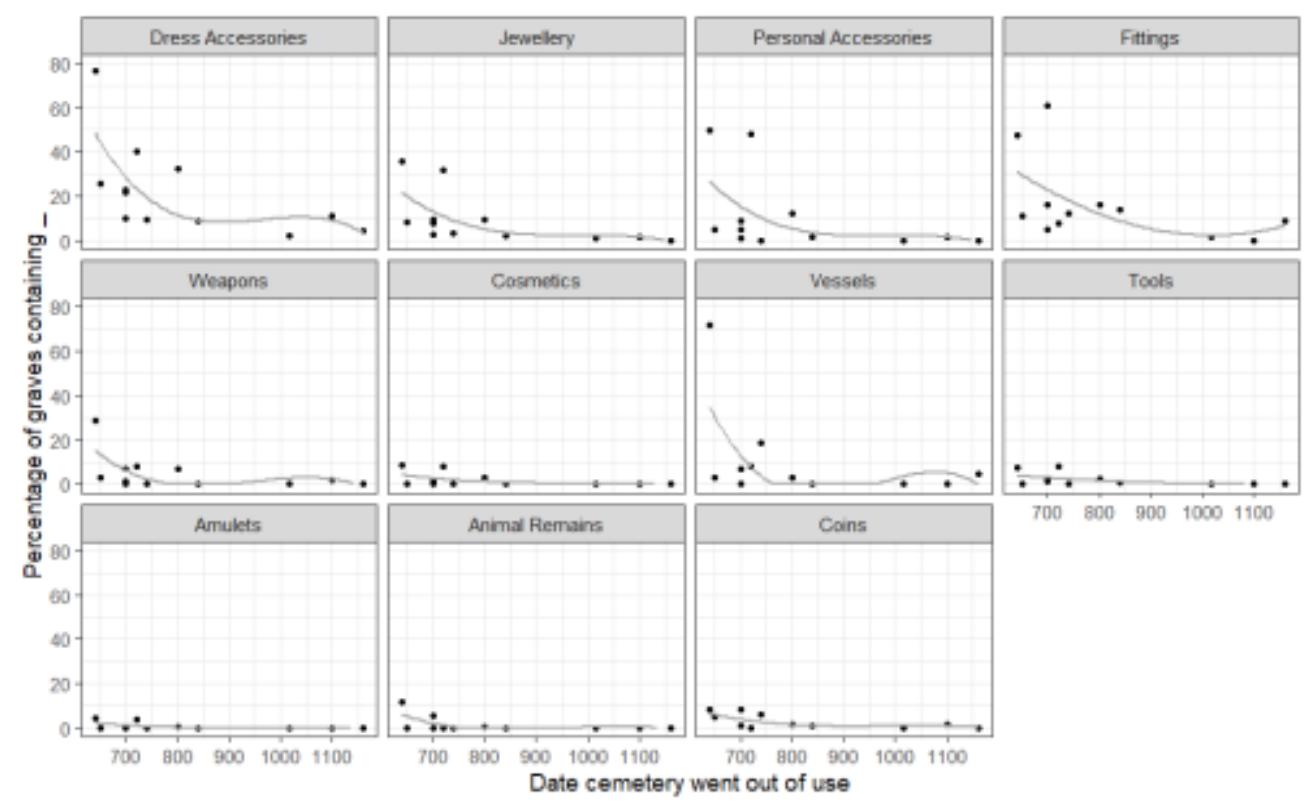

Figure 62: Changes in different types of grave goods in Burgundy

Table 20: Results of Kendall's tau-b for the correlation of presence/absence of object types in graves, with the date a cemetery went out of use in Burgundy. Statistically significant trends highlighted in yellow

\section{Change over the period of furnished burial $(\mathrm{N}=1950)$}

Type

Dress accessories

Jewellery
$T_{b}$-value

$-0.199$

$-0.144$

\section{P-value}

$<2.2 \mathrm{e}-16$

$9.673 e-12$ 
Personal accessories

Fittings

Weapons

Cosmetics

Vessels

Tools

Amulets

Animal remains

Coins
$-0.170$

$-0.133$

$-0.151$

$-0.054$

$-0.263$

$-0.048$

$-0.051$

$-0.112$

$-0.072$ 8.596e-16

3.041e-10

8.979e-13

0.01103

$<2.2 \mathrm{e}-16$

0.02415

0.01702

1.124e-07

0.0006698 


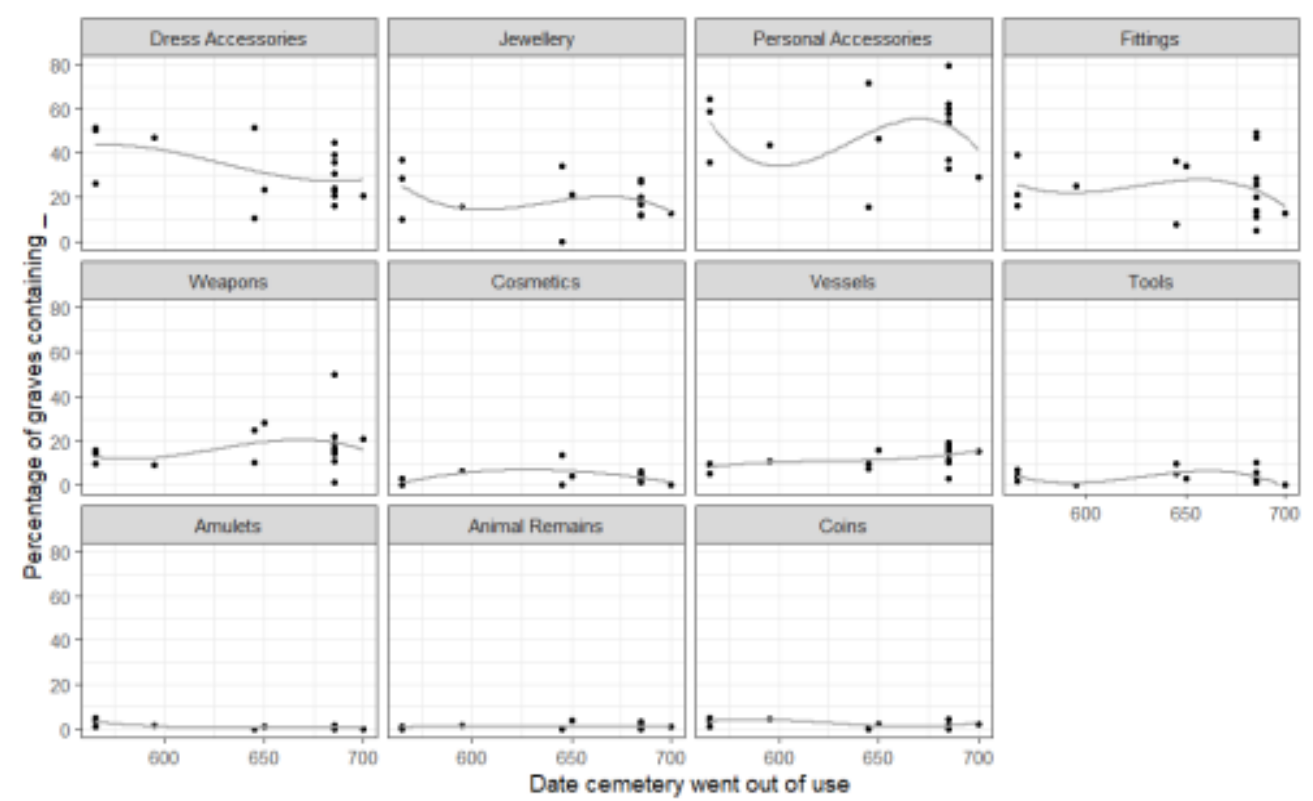

Figure 63: Changes in different types of grave goods in Kent

Table 21: Results of Kendall's tau-b for the correlation of presence/absence of object types in graves, with the date a cemetery went out of use in Kent. Statistically significant trends highlighted in yellow

\section{Change over the period of furnished burial ( $N=2547)$}

Type

Dress accessories

Jewellery
$T_{b}$-value

$-0.056$

$-0.034$
P-value

0.001915

0.06108 
Personal accessories

Fittings

Weapons

Cosmetics

Vessels

Tools

Amulets

Animal remains

Coins
0.034

0.06344

$-0.033$

0.07137

$-0.007$

0.6936

$-0.005$

0.779

0.045

0.01288

$-0.013$

0.4848

$-0.034$

0.06037

$-0.010$

0.5803

$-0.012$

0.5261 


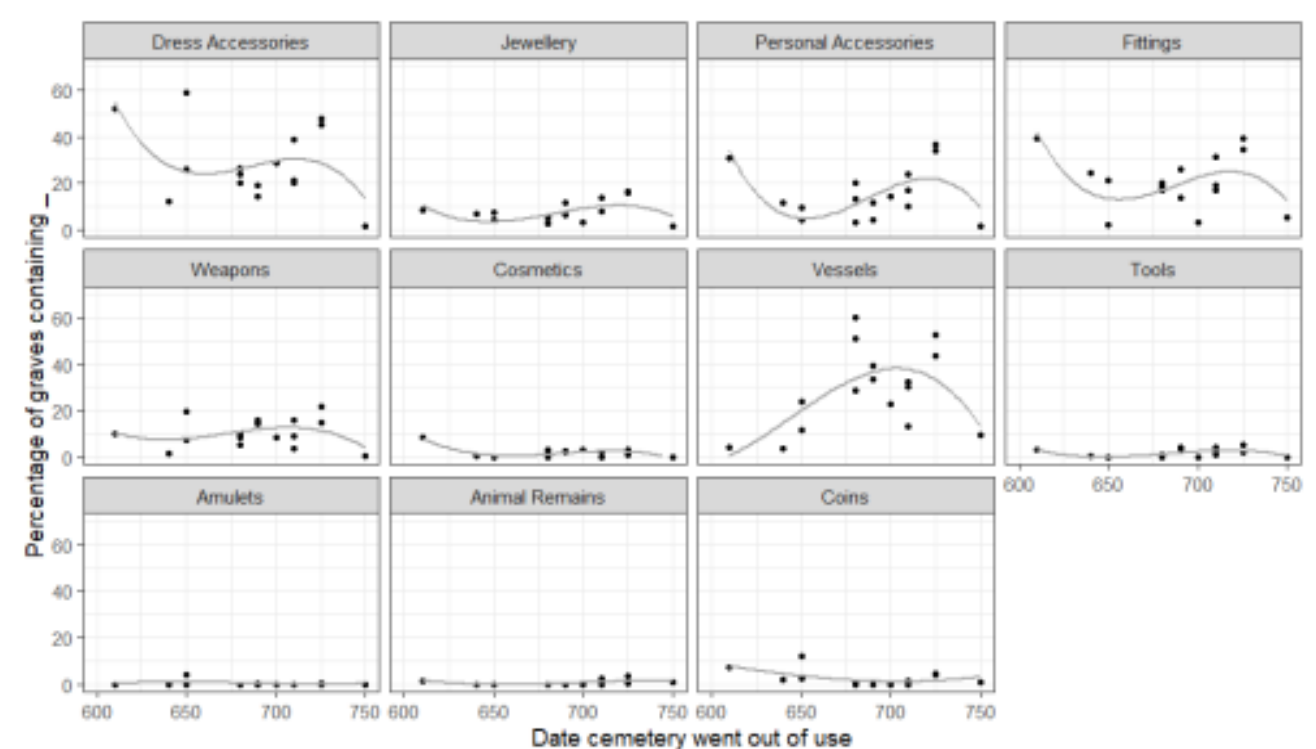

Figure 64: Changes in different types of grave goods in western Frankia

Table 22: Results of Kendall's tau-b for the correlation of presence/absence of object types in graves, with the date a cemetery went out of use in western Frankia. Statistically significant trends highlighted in yellow

\section{Change over the period of furnished burial $(\mathrm{N}=3071)$}

\section{Type}

Dress accessories

Jewellery

\section{$T_{b}$-value}

0.014

0.024
P-value

0.3866

0.1404 
Personal accessories

Fittings

Weapons

Cosmetics

Vessels

Tools

Amulets

Animal remains

Coins
0.061

0.004

$-0.004$

$-0.015$

0.055

$-0.004$

$-0.019$

0.023

0.006
0.0001474

0.8144

0.7918

0.3441

0.000591

0.8122

0.2309

0.149

0.7051 


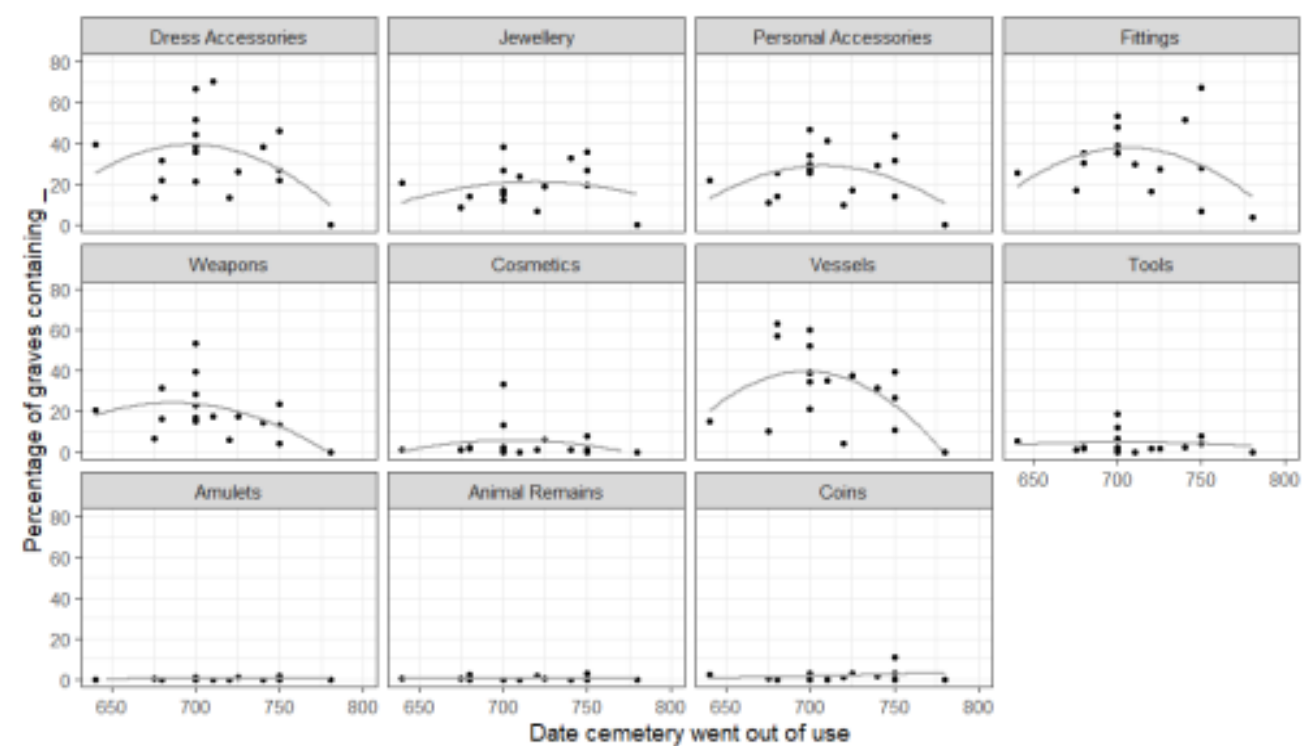

Figure 65: Changes in different types of grave goods in the Low Countries

Table 23: Results of Kendall's tau-b for the correlation of presence/absence of object types in graves, with the date a cemetery went out of use in the Low Countries. Statistically significant trends highlighted in yellow

\section{Change over the period of furnished burial $(\mathrm{N}=1790)$}

Type

Dress accessories

Jewellery

\section{$T_{b}$-value}

$-0.032$

0.051

\section{P-value}

0.1213

0.01374 


$\begin{array}{lll}\text { Personal accessories } & 0.045 & 0.02888 \\ \text { Fittings } & 0.055 & 0.007781 \\ \text { Weapons } & -0.051 & 0.01376 \\ \text { Cosmetics } & 0.03 & 0.1409 \\ \text { Vessels } & 0.042 & 0.04333 \\ \text { Tools } & & 0.7984 \\ \text { Amulets } & -0.005 & 0.4172 \\ \text { Animal remains } & 0.017 & 0.5358 \\ \text { Coins } & 0.013 & 0.02983\end{array}$




\section{$\underline{\text { 6. Discussion }}$}

This work highlights the variety between regions in grave good provision, and the variety in the way they initiated and responded to changing norms around burial practices. The reality will always be complex and nuanced, with exceptions to the rule, that highlight the importance of individual agency in shaping funerary traditions. Nevertheless, there are some overall trends that are worth discussing: the general trend towards unfurnished burial over time, even in areas that are sparsely furnished to begin with; the clear distinction between cemeteries of the 7th century and cemeteries of the 8th century; the zone of relatively conservative practice around the North Sea; and what the changes reveal about the significance of different grave goods in different regions.

It was already clear from Section 3 that the furnished burial rite took slightly different forms across Europe; the importance attached to different types of grave goods varied, and the motivations behind the inclusion of these different objects most likely also varied. The chronological analysis has provided greater clarity to these regional variations. Alamannia was generally a region of high levels of grave good deposition, with clear declines in the furnished funerary rite prior to the complete abandonment of furnished burial, and the Saxon and Anglian areas of England followed similar trends. Although richly furnished cemeteries did continue to be used right up until the end of furnished burial, they were joined by more poorly furnished sites that were not seen earlier. In both Alamannia and parts of England, this was a wholesale decline across most categories of objects, with a few exceptions, the most notable being personal accessories. Thus, the areas that were undergoing similar changes were separated by hundreds of miles, with intervening regions where funerary practices evolved in different ways. These similarities over large distances have been demonstrated in other aspects of early medieval material culture. Martin's (2020) study of bow brooches showed that the strongest similarities in brooch styles were found over great distances, rather than in immediately adjacent regions.

I would not interpret this change in funerary practices through any one explanation; it is too wide-ranging over regions with different political and cultural backgrounds, and attempting to come up with a single explanatory mechanism would inevitably end up being a gross over-simplification. I instead see it as a sign of connectivity between areas that allowed for the diffusion of cultural changes. Part of the motivation for change comes from a desire to adapt to the changing customs of their contemporaries (Brownlee 2021, 152-54). However, this more in-depth analysis has shown that not all regions were equally tied into this network of connectivity.

The most notable exceptions to the overall patterns are Kent, western Frankia, and the Low Countries and Moselle region, the only regions where there was no clear decline in grave goods prior to the abandonment of furnished cemeteries in the late 7th and early 8th centuries. Initially, proportions of grave good deposition differed; Kent and the Low Countries tended towards higher numbers of objects in graves than did western Frankia. But they all saw a consistent use of grave goods over the same time period, when elsewhere communities were gradually reducing their material investment in graves. Instead, in these regions the abandonment of grave goods was much more sudden, coming only as furnished burial was well on the decline in other areas. The relative conservatism of Kent has been noted in other studies; for example, Mui's study (2018, 114-15) of body positions in the grave showed that of all of England, Kent had some of the lowest levels of variation. Another parallel between Kent and western Frankia was 
the statistically significant increase in vessels, while most other categories of object showed no appreciable change. Vessels were one of the most important objects used in funerary rites in Frankia and continued to be so throughout the entire period of furnished burial. Although they were not initially a frequent object type in Kent, the fact that they became more common suggests their growing importance over time. This, along with the continued high levels of grave good use, suggests that these two regions were culturally intertwined. The communities in these areas, along with the Low Countries, were resistant to change, and preferred to maintain established traditions. The shift towards unfurnished burial came right at the end of the process of abandonment across Europe, with very little sign of changing practices beforehand, suggesting that it was only once pressure to conform with surrounding communities became overwhelming that practices shifted to match them. In those areas, therefore, the decision to abandon the use of these furnished cemeteries, and the grave goods within them, seems to have been a very deliberate one, taken as an intentional step to bring funerary practice in line with that in the rest of north-western Europe.

There is considerable evidence of political and cultural contact between Kent and Frankia that explains why these regions share funerary practices in a way that makes them distinct from other areas. Frankish historical sources suggest that Kent was under the political control of Frankish elites, although this may have been exaggerated (Brookes and Harrington 2010, 46) One of the key events in historical accounts of conversion is the marriage of the Frankish princess Bertha to Aethelbert of Kent (Burnell and James 1999,87$)$. Kent was the only region of England where imports were at all common in the 6th century, mostly luxury imports coming from Frankia, and most Frankish pottery found in England has been found in Kent (Wickham 2006, 808). Approximately $12 \%$ of all Kentish graves contained items in a Frankish style, and many grave assemblages contain objects originating in Frankia, including characteristic radiate-headed brooches, bird brooches, and kidney-shaped buckles among others (Brookes and Harrington 2010, 45; Soulat 2013, 208). Kentish material is also present in cemeteries in western Normandy, Frisia, and the Rhineland, although curiously there is an absence of Kentish objects among cemeteries between the Seine and the Somme (Brookes and Harrington 2010, 49). Kentish-style pottery has also been found in cemeteries and settlements right along the French Channel coast, but a petrographic analysis revealed that these were made of local clays, and so were not imports but copies; they are instead indicative of a level of cultural exchange that existed alongside the economic exchange evidenced by trading sites (Soulat et al. 2012, 219). There were not just exchanges of objects, but also movement of people; recent isotopic analysis has suggested a high number of individuals with non-local origins (Leggett 2021, 310-13) Other similarities in funerary practice can be seen in how common the practice of grave reopening was in Kent; this is also something that is found broadly across continental Europe, but only rarely in the rest of England (Klevnäs 2013, 34). Frankish objects in Kentish graves are less frequently found in the 7th century, which can be interpreted as a way of asserting independence from Frankia (Brookes and Harrington 2010, 56). However, the similar trajectories of grave good use in Kent and West Frankia suggest that these regions maintained a shared culture. This also emphasises the importance of looking at the ways in which types of objects were being used, rather than just at the styles of objects.

Burgundy also stands out as a region where there were exceptions to the overall pattern, though in terms of cemetery use rather than grave good decline. In most areas, as far as the evidence allows us in the absence of widescale radiocarbon dating, there was a clear change in the cemeteries in which burial took place around the latest stages 
of grave good use. This would not have been a decision that was taken lightly; there would have been an emotional attachment to the people buried in older cemeteries, especially immediate ancestors, suggesting that most people would have been reluctant to abandon such burial sites (Hassenpflug 1999, 63). Cemeteries, as places where communities regularly gathered for ritual performances, have an important role to play in maintaining the collective memory and social cohesion of a community (Moen 2020, 35). The abandonment of earlier sites could therefore be a way of deliberately 'forgetting', or rejecting, earlier practices (Hadley 2011, 305). Given that the use of grave goods was so different in the 6th to 7th, and 8th-century cemeteries, their abandonment could be seen as a conscious rejection of earlier practices. The abandonment of cemeteries took place at an advanced stage in the long process of abandoning grave goods, a process that in some areas had been ongoing for over a century. It was therefore only once unfurnished burial had become relatively well established that the conscious rejection of the sites in which furnished burial had been common was possible. The one exception to this is the region of Burgundy, the only area to see substantial continuity of sites across the entire period of study. Despite initially having relatively low levels of grave good use, this area still saw a significant decline. The region of Burgundy was part of a transitional zone between the largely unfurnished practices that were common further south, and the richer cemeteries of the north. The influence of the latter can be clearly seen in the cemetery of Saint Vit, which appeared far more like the Alamannic cemeteries than its immediate neighbours. Overall, though, the concept of completely unfurnished burial was more familiar in Burgundy than in other regions, so that the transition was an easy one for Burgundian communities to make. This meant that it was not necessary to abandon earlier sites in order to mark a clear distinction between furnished and unfurnished burial. Of the few examples of cemeteries that survive in continual use in other areas, all but two - Sainte Barbe (Blaizot et al . 2004) in southern Alamannia, and Metzervisse (Lansival 2007) in eastern Frankia - were largely unfurnished, and those two had only limited evidence for continued use.

One of the things that showed greatest regional variability was the way in which different object types declined, or continued to be used, regardless of how common they were initially. There was no region in which the use of every object type universally changed in the same way; northern Alamannia perhaps came closest to this with significant decreases in every object type, apart from personal accessories and animal remains. One of the most noticeable trends is the persistence with which personal accessories continued to be used (Brownlee 2020). These were one of the most commonly deposited types of object; in Anglo-Saxon cemeteries, they were found in $40-60 \%$ of graves, and in similar numbers in Alamannia, and while they were less common in Burgundy and western Frankia, they were still one of the more frequently used categories of object. Despite overall declines in grave good use, there was no statistically significant decrease in the use of personal accessories in northern Alamannia, eastern Frankia, and the Saxon parts of England, and they in fact became more commonly used in western Frankia. There was also no change in their use in Bavaria or Kent, though these were regions where there was very little overall decline in object types. Though their use did decline in Burgundy and Anglian regions, this was one of the smallest changes compared to other types of object. Southern Alamannia and the Lower Rhine were the only regions where there was anything more than a slight decrease in the use of personal accessories. Personal accessories can therefore be said to have held a special significance in the early medieval funerary rite, which transcended regional boundaries and contrasted to other types of grave goods. The category of personal accessories, including objects such as knives, keys, bags, and girdle hangers, comprised everyday objects that would have been carried and used 
frequently. This makes them a form of 'inseparable' possessions, items that are so closely entwined with the body of their owners that it was very difficult for them to be given away, and the bonds of possession remained so that even on death it was not possible to separate object from owner (Klevnäs 2015, 175; Brownlee 2020, 419). Because the connection was formed with the body, it existed across large parts of early medieval Europe, regardless of other funerary norms.

This was in contrast to objects such as dress accessories, which were even more commonly deposited in graves than were personal accessories; they were the most common object in almost all of the cemeteries studied, being found in roughly equal numbers to personal accessories in Anglo-Saxon sites, and it was only in the Lower Rhine where they were frequently outnumbered by vessels. They were one of the few objects that consistently became less frequently deposited in graves, regardless of region. Even in areas where there was no overall change in the level of furnishing, in Bavaria and Kent, dress accessories still became less commonly deposited. The only exception was western Frankia. Dress accessories were placed in the grave, not so much as possessions, gifts, or deliberate depositions, but as an integral part of the costume of the deceased (Lucy 2000,63 ). It has been suggested that dress accessories became less commonly placed in graves not because of any changes in their inherent importance as objects, but because of changing patterns in styles of dress that featured smaller, more discrete, accessories over the lavish display of earlier costumes (Martin 2015, 235). While this may partially be true, shrouded burial became increasingly favoured over dressed burial, suggesting a quite different approach to preparing the body (Mui 2015, 155), and a transformation in the importance of dress accessories.

Weapons also shared similar patterns of change to dress accessories; they only remained consistently used in the areas where there was otherwise very little decrease in objects, in western Frankia and in Kent, and they in fact became more commonly deposited in Bavaria. Weapons became less commonly used over time, particularly in adolescent graves, and the variety of weapons being used also decreased (Geake 1997, 129; Härke 1992, 159-60). However, those burials that still contained weapons remained relatively richly furnished, whereas the wealth of male burials without weapons strongly decreased (Härke 1992, 161). Weapon burial may increasingly have become more of a display of status than of gender in the 7th century, explaining why their general use declined.

With many of the other categories of object, especially the rarer types, there were no clear universal changes across all of the regions studied. The use of no other object type changed in such a consistent way as dress accessories, weapons, and personal accessories. The significance of many different types of object was largely determined on a regional, and perhaps even a local level. In the areas of particularly high vessel use, for example, vessels retained their importance; in areas where vessels were not so important, more marked changes were noted in their use. Thus only certain categories of artefact can be said to hold some level of universal meaning across western Europe.

\section{Conclusions}

Despite being a region that superficially shared a similar burial rite - the burial of dressed bodies with associated objects - and a region that superficially underwent a similar transition - an overwhelming shift towards unfurnished burial - there were nevertheless distinct differences between regions of early medieval north-western Europe that allow 
us to see the way connections, interactions, and cultural affinities ebbed and flowed over a wide area.

Looking at the cemeteries of the 6th century, it is possible to see areas that tend towards higher levels of grave good use, and those that tend towards lower levels of grave good use. Broadly speaking, these patterns hold true for most types of object, with one clear exception: vessels. Vessels stand out as an object type commonly found in areas where other types of objects are relatively rare. This speaks to a zone of quite different funerary practice, and potentially different ways of perceiving and interacting with the dead. Such use of vessels in this zone should be investigated further. These broad trends are only part of the story, however, and while those large-scale trends are undoubtedly meaningful, they should not fully eclipse the variability that exists within those regions. This variability signifies the ability of individuals and communities to adapt standard repertoires to their own needs, rather than following rigid rules about what was and was not acceptable to place with a burial. This analysis has focused primarily on the use of grave goods. However, the same issues of local variation and community choice are likely to have influenced other choices made around the funerary rite, such as inhumation versus cremation, body position, the use of coffins or receptacles for the body, and other aspects of grave construction.

As initial levels of grave good use showed several clear regional distinctions, but variability within those regions, so too did the way in which grave good use evolved over the course of the 7th and 8th centuries. While almost all regions show a decline in grave goods, accompanied by an abandonment of the cemeteries in which furnished burial was common, the pace of change, and the way in which different types of objects changed differed considerably. Changes in the frequency of different object types speak to more subtle distinctions, but most notable was the conservatism of regions bordering the North Sea, including Kent, western Frankia, the Low Countries and the Moselle. These regions formed an area where there was little overall decline in grave good use, in stark contrast to their surrounding areas. This suggests a relatively insular zone, emphasising internal shared culture, rather than more widespread links.

The complexity of this phenomenon means that any attempt to find a single explanation for it is doomed to failure. The stratification of social hierarchies (Halsall 2010), changing methods of commemoration (Williams 2006), and changing understanding of death and the dead body (Brownlee 2020) may all have been contributing factors. However, understanding burial change on a broad scale is important not only for identifying potential causes, but as a means of understanding how different areas related to one another. Looking at funerary variation and evolution across early medieval Europe demonstrates areas that were closely intertwined, but also areas that remained more separate, despite their geographical proximity.

\section{Acknowledgements}

This work was funded by as part of my PhD from an Arts and Humanities Research Council grant (ref no: 1808445). I would like to thank Susanne Hakenbeck for her advice throughout that PhD. I would also like to thank Alison Klevnäs for her comments on a draft of this paper, and Sam Leggett for her advice on using $R$. 


\section{Data}

https://intarch.ac.uk/journal/issue56/11/data.html

\section{Bibliography}

Ager, B.M. 1989 'The Anglo-Saxon cemetery' in I.M. Stead and V. Rigby Verulamium: the King Harry Lane site, London: English Heritage Archaeological Report 12. 21939. https://archaeologydataservice.ac.uk/archives/view/eh monographs 2014/contents. cfm?mono $=1089078$

Alenus, J. 1963 'Fouille mérovingienne à Folx-les-Caves', Archaeologia Belgica 69.

Alenus-Leclerf, J. 1975 'Le Cimetière Mérovingien de Hamoir, I.

Catalogue', Archaeologia Belgica 181.

Alenus-Leclerf, J. and Dradon, M. 1967 'Tombes Mérovingiennes à Hollogne-auxPierres', Archaeologia Belgica 101.

Ament, H. 1992 Das alamannische Gräberfeld von Eschborn (Main-Taunus-Kreis), Wiesbaden: Selbstverlag des Landesamtes für Denkmalpflege Hessen.

Annable, F.K. and Eagles, B.N. 2010 The Anglo-Saxon Cemetery at Blacknall Field, Pewsey, Wiltshire, Devizes: Wiltshire Archaeological and Natural History Society.

Arnold, S. 1992 Das bajuwarische Reihengräberfeld von Steinhöring, Landkreis Ebersberg, Münster: Lit.

Barat, Y., Langlois, M. and Bricon, D. 2001 'Habitats et nécropoles du haut Moyen-Âge en vallée de Vaucouleurs (sites de Septeuil et Villette, Yvelines)', Revue archéologique du Cente de la France 40, 133-65. https://doi.org/10.3406/racf.2001.2878

Bayard, D., Piton, D. and Schuler, R. 1981 'Le cimetière mérovingien de Moreuil (Somme)', Revue archéologique de Picardie 8, 157-

216. https://doi.org/10.3406/pica.1981.1337

Berthelier-Ajot, N. 1982 'Le cimetière mérovingien de Bonnières (Oise)', Revue archaéologique de Picardie 4, 159-77. https://doi.org/10.3406/pica.1982.1370

Billoin, D., Gaillard de Sémainville, H. and Moulherat, C. 2006 'La nécropole du haut Moyen Âge de Largillay-Marsonnay 'Sur le Marteret' (Jura)', Revue Archéologique de l'Est 55, 225-56.

Billoin, D., Châtelet, M., Putelat, O. and Thiol, S. 2008 'La nécropole mérovingienne à tumuli d'Hégenheim (Haut-Rhin)' in J. Guillaume and E. Peytremann (eds) L'Austrasie: Sociétés, économies, territoires, christianisation: Actes des XXVle Journées 
internationales d'archéologie mérovingienne, Nancy 22-25 septembre 2005, Nancy: Presses Universitaires de Nancy. 269-81.

Birbeck, V., Smith, R., Andrews, P., Stoodley, N., James, S.E. and Goller, R. 2005 The Origins of Mid-Saxon Southampton: Excavations at the Friends Provident, St Mary's Stadium, 1998-2000, Salisbury: Wessex Archaeology.

Blair, J. 2005 The Church in Anglo-Saxon Society, Oxford: Oxford University Press.

Blaizot, F., Bonnet, C., Castex, D., Duday, H., Cécillon, C., Frascone, D., Macabéo, G., Roger, K., Rolland, M., Martin, S., Staniaszek L. and BenNcer, A. 2001 'Trois cimetières ruraux de l'Antiquité tardive dans la moyenne vallée du Rhône: Les sites du Pillon à Marennes (Rhône), du Trillet à Meyzieu (Rhône) et des Girardes à Lapalud (Vaucluse)', Gallia 58, 271-361. https://doi.org/10.3406/galia.2001.3028

Blaizot, F., Baudoux, J., Thomann, E., Boës, E., Boës, X., Flotte, P. and Macabeo, G. 2004 'L'ensemble funéraire de l'Antiquité tardive et du haut Moyen Âge de Sainte-Barbe à Strasbourg (Bas-Rhin)', Revue archéologique de l'Est 53, 85-188.

Boddington, A. 1990 'Modes of burial, settlement, and worship: the final phase reviewed' in E. Southworth (ed) Anglo-Saxon Cemeteries: a reappraisal, Stroud: Sutton. 177-99.

Bonvalot, N. 2003 'Les Nécropole Mérovingiennes d'Évans (Jura) et le context de la moyenne vallée du Doubs depuis la fin de l'Antiquité' in F. Passard-Urlacher (ed) Burgondes, Alamans, Francs, Romains dans l'est de la France, le sud-ouest de l'Allemagne et la Suisse, Ve-VIle siècle après J-C: Actes des XXle journées internationales d'archéologie mérovingienne, Besançon, 20-22 octobre 2000, Besançon: Presses Universitaires Franc-Comtoises. 111-28.

Boyle, A., Dodd, A., Miles, D. and Mudd, A. 1995 Two Oxfordshire Anglo-Saxon Cemeteries: Berinsfield and Didcot, Oxford: Oxford University Committee for Archaeology.

Boyle, A., Barclay, A. and Jennings, D. 1998 The Anglo-Saxon Cemetery at Butler's Field, Lechlade, Gloucestershire. Volume 1, Prehistoric and Roman activity and grave catalogue, Oxford: Oxford University Committee for Archaeology.

Brather, S. 2002 'Ethnic identities as constructions of archaeology: the case of the Alamanni' in A. Gillet (ed) On Barbarian Identity: Critical Approaches to Ethnicity in the Early Middle Ages, Turnhout: Brepols. 149-75. https://doi.org/10.1484/M.SEMEB.3.4487

Brookes, S. and Harrington, S. 2010 The Kingdom and People of Kent AD 400-1066: their history and archaeology, Stroud: The History Press.

Brownlee, E.C. 2020 'The dead and their possessions: the declining agency of the cadaver in Early Medieval Europe', European Journal of Archaeology 23(3), 40627. https://doi.org/10.1017/eaa.2020.3

Brownlee, E.C. 2021 'Connectivity and funerary change in Early Medieval Europe', Antiquity 95(379), 142-59. https://doi.org/10.15184/aqy.2020.153 
Brulet, R. and Coulon, G. 1990 Les Fouilles du Quartier Saint-Brice à Tournai:

L'environnement funéraire de la sépulture de Childéric, Louvain-La-Neuve: Département d'archéologie et d'histoire de l'art, Université catholique de Louvain.

Brulet, R. and Moureau, G. 1979 La nécropole mérovingienne 'En Village' à Braives, Louvain-la-Neuve: Institut supérieur d'archéologie et d'histoire de l'art.

Buchta-Hohm, S. 1996 Das alamannische Gräberfeld von Donaueschinge, Stuttgart: Theiss.

Buckberry, J. 2010 'Cemetery diversity in the Mid- to Late Anglo-Saxon period in Lincolnshire and Yorkshire' in J. Buckberry and A. Cherryson (eds) Burial in Later AngloSaxon England c. 650-1100 AD, Oxford: Oxbow Books. 1-25.

Bullough, D. 1983 'Burial, community and belief in the Early Medieval West' in P. Wormald, D. Bullough and R. Collins (eds) Ideal and Reality in Franish and Anglo-Saxon Society: studies presented to J.M. Wallace-Hadrill, Oxford: Blackwell. 177-201.

Burnell, S. 1998 Die reformierte Kirche von Sissach BL: mittelalterliche Kirchenbauten und merowingerzeitliche 'Stiftergräber', Liestal: Archäologie und Kantonsmuseum Baselland.

Burnell, S. and James E. 1999 'The archaeology of conversion on the continent in the sixth and seventh centuries: some observations and comparisons with Anglo-Saxon England' in R. Gameson (ed) St Augustine and the Conversion of England, Stroud: Alan Sutton. 83-106.

Burnell, S., Lorans, E. and Theureau, C. 1994 'La nécropole du haut Moyen-Âge de La Mouline à Saint-Firmin-des-Prés (Loir-et-Cher)', Revue archéologique du Centre de la France 33, 133-90. https://doi.org/10.3406/racf.1994.2711

Capelle, T. 1979 Das Gräberfeld Beckum I, Münster: Aschendorff.

Chadwick Hawkes, S. and Grainger, G. 2003 The Anglo-Saxon Cemetery at Worthy Park, Kingsworthy, near Winchester, Hampshire, Oxford: Oxford University School of Archaeology.

Chadwick Hawkes, S. and Grainger, G. 2006 The Anglo-Saxon Cemetery at Finglesham, Kent, Oxford: Oxford University School of Archaeology.

Chambers, R.A. 1976 'The cemetery site at Beacon Hill, near Lewknor, Oxon, 1972: an inventory of the inhumations and a re-appraisal', Oxoniensia 41, 77-

85. https://www.oxoniensia.org/volumes/1976/chambers5.pdf

Chevalier, M., Gaillard de Semainville, H. and Michaut, J.P. 1984 'La nécropole Mérovingienne de la Verrerie a Velars-sur-Ouche (Côte-d'Or)', Revue Archéologique de I'Est et du Centre-Est 35(3-4), 319-56.

Chopelain, P. and Watel, F. 2003 'La nécropole mérovingienne de Mollans 'En Progrige' (Haute-Saône)' in F. Passard-Urlacher (ed) Burgondes, Alamans, Francs, Romains dans l'Est de la France, le Sud-ouest de l'Allemagne et la Suisse, Ve-VIle siècle après J-C: 
Actes des XXle journées internationales d'archéologie mérovingienne, Besançon, 20-22 octobre 2000, Besançon: Presses Universitaires Franc-Comtoises. 129-42.

Clauss, G. 1986 'Ein neuer Reihengräberfriedhof bei Hockenheim, Rhein-NeckarKreis', Fundberichte Aus Baden Württemberg 11, 313-58.

Codreaunu-Windauer, S. and Hundt, H. 1997 Pliening im Frühmittelalter: Bajuwarisches Gräberfeld, Siedlungsbefunde und Kirche, Kallmünz: M. Lassleben.

Cook, A.M. and Dacre, M.W. 1985 Excavations at Portway, Andover 1973-1975: AngloSaxon cemetery, Bronze Age barrow and linear ditch, Oxford: Oxford University School of Archaeology.

Corrochano, A. and Soulat, J. 2017 'Le petit mobilier présent dans les tombes 'carolingiennes' en France: état de la question et première approche' in S. De Larminat, R. Corbineau, A. Corrochano, Y. Gleize, and J. Soulat (eds) Rencontre Autour de Nouvelles Approches de l'Archéologie Funéraire, 6ème Rencontre du Groupe d'anthropologie et d'archéologie funéraire, avril 2014, INHA, Paris, Paris: GAAF. 97-109.

Cosack, E. and Hässler, H. 1982 Das sächsische Gräberfeld bei Liebenau, Kr. Nienburg (Weser), Berlin: Mann.

Cox, P.W. 1988 'A seventh century inhumation cemetery at Shepherd's Farm, Ulwell near Swanage, Dorset', Proceedings of the Dorset Natural History and Archaeology Society 110, 37-45.

Czermak, A., Ledderose, A., Strott, N., Meier, T. and Grupe, G. 2006 'Social structures and social relations - an archaeological and anthropological examination of three Early Medieval separate burial sites in Bavaria', Anthropologischer Anzeiger 64, 297310. https://doi.org/10.1127/anthranz/64/2006/297

Dannheimer, H. 1968a Epolding-Mühlthal: Siedlung, Friedhöfe und Kirche des frühen Mittelalters, München: C.H. Beck.

Dannheimer, H. 1968b Lauterhofen im frühen Mittelalter: Reihengräberfeld, Martinskirche, Königshof, Kallmünz: M. Lassleben.

Dannheimer, H. 1971 'Zur Geschichte von Brenz und Sontheim im frühen Mittelalter', Fundberichte Aus Schwaben 19, 298-308.

Dannheimer, H. 1998 Das baiuwarische Reihengräberfeld von Aubing, Stadt München, Stuttgart: K. Theiss.

Dannheimer, H. and Diepolder, G. 1988 Aschheim im frühen Mittelalter, München: Beck.

Darling, M., Gurney, D. and Anderson, S. 1993 Caister-on-Sea Excavations by Charles Green, 1951-55, Gressenhall: Norfolk Museum Service. http://eaareports.org.uk/publication/report60/

De Boe, G. 1970 'Een Merovingisch grafveld te Borsbeek (Antwerpen)', Archaeologia Belgica 120. 
Decaens, J. 1971 'Un nouveau cimetière du haut moyen âge en Normandie:

Hérouvillette (Calvados)', Archéologie médiévale 1, 1-

125. https://doi.org/10.3406/arcme.1971.1226

Decormeille-Patin, C., Blondiaux, J. and Vallet, F. 1999 'Le cimetière mérovingien de Montataire (Oise)', Revue archéologique de Picardie 1-2, 83-

182. https://doi.org/10.3406/pica.1999.2207

Delort, E. 1947 'Le cimetière franc d'Ennery (Moselle)', Gallia 5(2), 351 -

403.https://doi.org/10.3406/galia.1947.2045

Demolon, P. 2006 La Nécropole Mérovingienne de Hordain (Nord): Vle-IXe siècles après J.-C, Douai: Communauté d'agglomération du douaisis, direction de l'archéologie.

Derks, T. and de Fraiture, B. 2015 Eens Romeins Heiligdom en een Vroegmiddeleeuws Grafveld bij Buchten (L): Verslag van een archeologisch noodonderzoek (1976),

Amersfoort: Rijksdienst voor het Cultureel Erfgoed.

Desbrosse-Degobertière, S. 2010 Vestiges d'une nécropole mérovingienne: Arrentières (Aube) 'Cercueil': rapport de fouilles, Metz: Inrap GEN.

Desbrosse-Degobertière, S. and Bonnabel, L. 201017 nouvelles tombes mérovingiennes découvertes à Saint-Marcel: Saint-Marcel, Ardennes, 'Village': rapport de fouilles, Metz: Inrap GEN.

Devlin, Z. 2007 'Social memory, material culture and community identity in Early Medieval burial practices' in H. Williams and S. Semple (eds) Anglo-Saxon Studies in Mortuary Identity and History 14: Early Medieval Mortuary Practices, Oxford: Oxbow Books. 38-46. https://doi.org/10.2307/j.ctvh1dq9h.10

Dodwell, N., Lucy, S. and Tipper, J. 2004 'Anglo-Saxons on the Cambridge Backs: the Criminology Site settlement and King's Garden Hostel cemetery', Proceedings of the Cambridge Antiquarian Society 93, 95-124. https://doi.org/10.5284/1073321

Down, A. and Welch, M. 1990 Chichester Excavations 7: Apple Down and the Mardens, Chichester: Chichester District Council.

Drinkall, G. and Foreman, M. 1998 The Anglo-Saxon Cemetery at Castledyke South, Barton-on-Humber, Sheffield: Sheffield Academic Press.

Duncan, H., Duhig, C. and Phillips, M. 2003 'A late migration/final phase cemetery at Water Lane, Melbourn', Proceedings of the Cambridge Antiquarian Society 92, 57134. https://doi.org/10.5284/1073313

Durand, M. and Vanhaeke, L. 1987 'La nécropole du haut Moyen Age et le moulin médiéval de Sacy-le-Petit (Oise)', Revue archéologique de Picardie 3-4, 83-

114. https://doi.org/10.3406/pica.1987.1524

Düring, A. 2014 'Der Friedhof von Bärenthal auf der Scherra - Lebensverhälltnisse und Bestattungsbrauch einer Dorfbevölkerung des 7. bis 10. Jahrhunderts', Fundberichte Aus Baden Württemberg 34(2), 391-490. 
Effros, B. 2002 Creating Community with Food and Drink in Merovingian Gaul, Basingstoke: Palgrave Macmillan. https://doi.org/10.1007/978-1-349-62577-2

Effros, B. 2003 Merovingian Mortuary Archaeology and the Making of the Middle Ages, Berkeley: University of California

Press. https://doi.org/10.1525/california/9780520232440.001.0001

Evison, V. 1987 Dover: the Buckland Anglo-Saxon Cemetery, London: Historic Buildings and Monuments Commission for

England. https://archaeologydataservice.ac.uk/archives/view/eh monographs 2014/cont ents.cfm?mono $=1089023$

Evison, V. 1994 An Anglo-Saxon Cemetery at Great Chesterford, Essex, York: Council for British Archaeology. https://doi.org/10.5284/1081774

Evison, V. and Allen, D. 1988 An Anglo-Saxon Cemetery at Alton, Hampshire, Winchester: Hampshire Field Club and Archaeological Society.

Evison, V. and Hill, P. 1996 Two Anglo-Saxon Cemeteries at Beckford, Hereford and Worcester, York: Council for British Archaeology. https://doi.org/10.5284/1081766

Faider-Feytmans, G. 1970 Les nécropoles mérovingiennes, Morlanwelz-Mariemont: Musée de Mariemont.

Fehring, G.P., Scholkmann, B. and Anstett, P. 1995 Die Stadtkirche St. Dionysius in Esslingen a.N: Archäologie und baugeschichte, Stuttgart: Theiss.

Fern, C. 2015 Before Sutton Hoo: the prehistoric remains and Early Anglo-Saxon cemetery at Tranmer House, Bromeswell, Suffolk, Norwich: East Anglian

Archaeology 155.

Filmer-Sankey, W. and Pestell, T. 2001 Snape Anglo-Saxon Cemetery: Excavations and surveys 1824-1992, Ipswich: Archaeological Service, Suffolk County

Council. http://eaareports.org.uk/publication/report95/

Fingerlin, G. 1971 Die alamannischen Gräberfelder von Güttingen und Merdingen in Südbaden, Berlin: de Gruyter.

Fischer, T. and Hundt, H. 1993 Das bajuwarische Reihengräberfeld von Staubing: Studien zur Frühgeschichte im bayerischen Donauraum, Kallmünz: M. Lassleben.

Flèche-Mourgues, M. 1988 'La nécropole mérovingienne de Vorges (Aisne)' Revue Archéologique De Picardie 3(1), 89-125. https://doi.org/10.3406/pica.1988.1534

Fossurier, C. 2008 'Une nécropole mérovingienne: Petit groupe d'inhumations et pratiques funéraires (Chanteloup-en-Brie, Ile-de-France)', Socio-Anthropologie 22, 3954. https://doi.org/10.4000/socio-anthropologie.1143

Fremersdorf, F. 1995 Das fränkische Reihengräberfeld Köln-Müngersdorf, Berlin: W. de Gruyter. 
Fréville, C. and Journa, R. 1994 'La nécropole mérovingienne de Longueil-Annel (Oise)', Revue Archéologique De Picardie 1(1), 87-

178. https://doi.org/10.3406/pica.1994.2140

Friedrich, M. 2016 Archäologische Chronologie und historische Interpretation : Die Merowingerzeit in Süddeutschland, Berlin: De

Gruyter. https://doi.org/10.1515/9783110475340

Gallien, V. 2009 Commune de Chéméré (Loire-Atlantique), Le Brigandin: une nécropole mérovingienne: rapport de fouilles, Cesson-Sévigné: Inrap

GO. https://doi.org/10.4000/adlfi.2136

Garner, M.F. 1993 'Middle Saxon evidence at Cook Street, Southampton

(SOU254)', Proceedings of the Hampshire Field Club and Archaeological Society 49, 77-

127. https://www.hantsfieldclub.org.uk/publications/hampshirestudies/digital/1990s/vol49 /Garner.pdf

Garner, M.F., Brown, D.H., Hamilton-Dyer, S., McKinley, J.I. and Russel, A.D. 2001 'A middle Saxon cemetery at Cook Street, Southampton (SOU283)', Proceedings of the Hampshire Field Club and Archaeological Society 56, 170-

91. https://www.hantsfieldclub.org.uk/publications/hampshirestudies/digital/2000s/vol56/ Garner.pdf

Geake, H. 1997 The Use of Grave Goods in Conversion Period England, Oxford: British Archaeol. Rep. https://doi.org/10.30861/9780860549178

Geisler, H. and Ganslmeier, R. 1998 Das frühbairische Gräberfeld StraubingBajuwarenstrasse I, Rahden: M. Leidorf.

Giesler-Müller, U. 1992 Das frühmittelalterliche Gräberfeld van Basel-Kleinhüningen: Katalog und Tafeln, Derendingen-Solothurn: Habegger.

Gilles, F. 2008 'La nécropole mérovingienne de Crotenay (Jura): pratiques funéraires et population' in J. Guillaume and E. Peytremann (eds) L'Austrasie: Sociétés, économies, territoires, christianisation: Actes des XXVle Journées internationales d'archéologie mérovingienne, Nancy 22-25 septembre 2005, Nancy: Presses Universitaires de Nancy. 295-302.

Green, B. and Rogerson, A. 1978 The Anglo-Saxon Cemetery at Bergh Apton, Norfolk, Gressenhall: Norfolk Archaeological

Unit. https://archaeologydataservice.ac.uk/library/browse/issue.xhtml?recordld=1140507 \&recordType=MonographSeries

Green, B., Rogerson, A. and White, S. 1987 The Anglo-Saxon Cemetery at Morning Thorpe, Norfolk, Dereham: Norfolk Archaeological Unit. http://eaareports.org.uk/publication/report36/

Grohne, E. 1953 Mahndorf: Fruhgeschichte des bremischen Raums, Bremen: W. Horn.

Groove, A.M. 2001 Das alamannische Gräberfeld von Munzingen/Stadt Freiburg, Stuttgart: Konrad Theiss Verlag. 
Grüninger, I., Kaufmann, B. and Schoch, W. 1988 'Ausgrabungen in der Pfarrkirche St. Peter und Paul in Mels SG', Archäologie Der Schweiz, 11(4), 155-66.

Haas, M., Theuws, F., Brandenburgh, C.R., Panhuysen, R., Oosterbaan, J., Hendriks, J. and Smits, L. 2013 The Merovingian Cemetery of Posterholt-Achterste Voorst, Bonn: Habelt-Verlag.

Hadley, D. 2002 'Burial practices in Northern England in the later Anglo-Saxon period' in S. Lucy and A. Reynolds (eds) Burial in Early Medieval England and Wales, London: Society for Medieval Archaeology. 209-28.

Hadley, D. 2011 'Late Saxon burial practice' in H. Hamerow, D. Hinton and S. Crawford (eds) The Oxford Handbook of Anglo-Saxon Archaeology, Oxford: Oxford University Press. 288-314. https://doi.org/10.1093/oxfordhb/9780199212149.013.0016

Hakenbeck, S. 2011 Local, Regional and Ethnic Identities in Early Medieval Cemeteries in Bavaria, Florence: All'insegna del giglio.

Hall, R.A. and Whyman, M. 1996 'Settlement and monasticism at Ripon, North Yorkshire, from the 7th to 11th Centuries AD', Medieval Archaeology 40, 62150. https://doi.org/10.1080/00766097.1996.11735599

Halsall, G. 1992 'The origins of the Reihengraberzivilisation: forty years on' in J. Drinkwater and H. Elton (eds) Fifth Century Gaul: A Crisis of Identity?, Cambridge: Cambridge University Press. 196-207.

Halsall, G. 1995 Early Medieval Cemeteries: an introduction to burial archaeology in the post-Roman West, Cruithne Press.

Halsall, G. 1996 'Female status and power in early Merovingian central Austrasia: the burial evidence', Early Medieval Europe 5(1), 1-24. https://doi.org/10.1111/j.1468$\underline{0254.1996 . t b 00045 . x}$

Halsall, G. 1998 'Burial, ritual, and Merovingian society' in J. Hill and M. Swann (eds) The Community, the Family, and the Saint: Patterns of Power in Early Medieval Europe: Selected Proceedings of the International Medieval Congress, University of Leeds, 4-7 July 1994, 10-13 July 1995, Brepols. 325-38. https://doi.org/10.1484/M.IMREB.4.00069

Halsall, G. 2010 Cemeteries and society in Merovingian Gaul: selected studies in history and archaeology, 1992-2009, Leiden: Brill. https://doi.org/10.1163/ej.9789004179998.i$\underline{422}$

Härke, H. 1992 'Changing symbols in a changing society: the Anglo-Saxon weapon burial rite in the seventh century' in M. Carver (ed) The Age of Sutton Hoo: the seventh century in north-western Europe, Woodbridge: Boydell. 149-66.

Harland, J. 2019 'Memories of migration? The 'Anglo-Saxon' burial costume of the fifth century AD', Antiquity 93(370), 954-969. https://doi.org/10.15184/aqy.2019.60

Harrington, S. and Brookes, S. 2008 Anglo-Saxon Kent Electronic Database, York: Archaeology Data Service [distributor] https://doi.org/10.5284/1000069 
Hassenpflug, E. 1999 Das Laienbegräbnis in der Kirche: historisch-archäologische Studien zu Alemannien im frühen Mittelalter, Rahden: M. Leidorf.

Haughton, C. and Powlesland, D. 1999 West Heslerton: the Anglian Cemetery, Yedingham: Landscape Research Centre.

Heeren, S. and Hazenberg, T. 2010 Voorname Dames, Stoere Soldaten en Eenvoudige Lieden, Leiden: Hazenberg Archeologie.

Herget, M. 2006 Das fränkische Gräberfeld von Rödingen, Kr. Düren: Chronologie und Belegungsabfolge, Rahden/Westf.: Verlag Marie Leidorf.

Hills, C. 2003 Origins of the English, London: Duckworth.

Hills, C., Penn, K. and Rickett, R. 1984 The Anglo-Saxon Cemetery at Spong Hill, North Elmham. Part III: Catalogue of inhumations, Gressenhall: Norfolk Archaeological Unit. https://archaeologydataservice.ac.uk/archives/view/eaa/contents.cfm?volume id=1 $\underline{144}$

Hincker, V. and Mayer, A. 2011 'La courte histoire du cimetière mérovingien de Banneville-la-Campagne (Calvados, France)', Archéologie médiévale 41, 1-

48. https://doi.org/10.4000/archeomed.11315

Hines, J. and Bayliss, A. (eds) 2013 Anglo-Saxon Graves and Grave Goods of the 6th and 7th Centuries AD: a chronological framework, London: Society for Medieval Archaeology.

Hinz, H. 1969 Das fränkische Gräberfeld von Eick, Gemeinde Rheinkamp, Kreis Moers, Berlin: Gebr. Mann.

Hirst, S. 1985 An Anglo-Saxon Inhumation Cemetery at Sewerby, East Yorkshire, York: Department of Archaeology, University of York.

Hirst, S. and Clark, D. 2009 Excavations at Mucking. Volume 3: the Anglo-Saxon cemeteries, London: Museum of London Archaeology.

Höke, B. 2013 'Das spätmerowingerzeitliche Gräberfeld von Neuburg a. d. Donau, St. Wolfgang: Anmerkungen zur Chronologie und Ergebnisse der 14C-Datierung', Bericht der Bayerischen Bodendenkmalpflege 54, 397-402.

Huggins, P.J. 1978 'Excavation of Belgic and Romano-British farm with Middle Saxon cemetery and churches at Nazeingbury', Transactions of the Essex Archaeological Society 10, 29-117.

Hyslop, M. 1963 'Two Anglo-Saxon cemeteries at Chamberlains Barn, Leighton Buzzard', Archaeological Journal 120(1), 161200. https://doi.org/10.1080/00665983.1963.10854239

Jansen, M. 2003 'Das merowingerzeitliche Gräberfeld auf Gewann, Weckersgraben in Buggingen, Kreis Breisgau-Hochschwarzwald', Fundberichte Aus Baden Württemberg 27, 775-916. 
Janssen, W. 1993 Das Fränkische Reihengräberfeld von Rödingen, Kr. Düren, Stuttgart: Steiner.

Jemiller, E. 1996 'Gräber der Jüngeren Merowingerzeit aus Weißenburg i. Bay', Bericht Der Bayerischen Bodendenkmalpflege 36/37, 169-306.

Johnson, S. 1983 Burgh Castle, Excavations by Charles Green 1958-61, Dereham: Norfolk Archaeological Unit. http://eaareports.org.uk/publication/report20/

Kars, M., Theuws, F., Haas, M., Hendriks, J., Jagt, I. and Smits, L. 2016 The Merovingian Cemeteries of Sittard-Kemperkoul, Obbicht-Oude Molen and Stein-Groote Bongerd, Bonn: Habelt-Verlag.

Klevnäs, A. 2013 Whodunnit? Grave Robbery in Anglo-Saxon England and the Merovingian Regions, British Archaeol. Rep. International Series 2852, Oxford: Archaeopress. https://doi.org/10.30861/9781407312071

Klevnäs, A. 2015 'Give and take: grave goods and grave robbery in the early middle ages' in A. Klevnäs and C. Hedenstierna-Jonson (eds) Own and be Owned: archaeological approaches to the concept of possession, Stockholm: Stockholm Studies in Archaeology 62. 157-88.

Knaut, M. 1993 Die alamannischen Gräberfelder von Neresheim und Kösingen, Ostalbkreis, Stuttgart: Kommissionsverlag K. Theiss.

Knocker, G.M. 1956 'Early burials and an Anglo-Saxon cemetery at Snell's Corner, near Horndean, Hampshire', Papers and Proceedings of the Hampshire Archaeological Society 19, 117-

70. https://www.hantsfieldclub.org.uk/publications/hampshirestudies/digital/1950s/vol19/ Knocker.pdf

Knol, E., Prummel, W., Uytterschaut, H.T., Hoogland, M.L.P., Casparies, W.A., De Langen, G.J. and Schelvis, J. 1996 'The early medieval cemetery of Oosterbeintum (Friesland)', Palaeohistoria 37/38, 245-416.

Koch, U. 1968 Die Grabfunde der Merowingerzeit aus dem Donautal um Regensburg, Berlin: De Gruyter. https://doi.org/10.1515/9783110826159

Koch, U. 1977 Das Reihengräberfeld bei Schretzheim, Berlin: Mann.

Koch, U. 1982 Die fränkischen Gräberfelder von Bargen und Berghausen in Nordbaden, Stuttgart: Theiss.

Koch, U. 1990 Das fränkische Gräberfeld von Klepsau im Hohenlohekreis, Stuttgart: Konrad Theiss Verlag.

Koch, U. 2001 Das alamannisch-fränkische Gräberfeld bei Pleidelsheim, Stuttgart: Kommissionsverlag K. Theiss.

La Baume, P. 1967 Das fränkische Gräberfeld von Junkersdorf bei Köln, Berlin: Mann. 
Lansival, R. 2007 'La nécropole mérovingienne de Metzervisse (Moselle)', Revue archéologique de l'Est 56, 231-310.

Le Boulanger, F., Chollet, S., Colleter, R. and Jean, S. 2005 Bréal-sous-Vitré, "Le Bourg" (Ille-et-Vilaine): Rapport de fouilles: Approche d'un cimetière du haut Moyen-Âge au début de l'époque Moderne, Cesson-Sévigné: Inrap GO.

Leahy, K. 2007 'Interrupting the pots': the Excavation of Cleatham Anglo-Saxon Cemetery, North Lincolnshire, York: Council for British Archaeology.

Leggett, S. 2021 'Tell me what you eat, and I will tell you who you are': A Multi-Tissue and Multi-Scalar Isotopic Study of Diet and Mobility in Early Medieval England and its European Neighbours, Unpublished PhD thesis, University of

Cambridge https://doi.org/10.17863/CAM.63545

Legoux, R. 1980 'La nécropole mérovingienne de Cuignières (Oise). Chronologie par permutations matricielles et répartitionstopographiques', Cahiers archéologiques de Picardie 7, 211-22. https://doi.org/10.3406/pica.1980.1316

Legoux, R. 2001 La Nécropole Mérovingienne de Bulles (Oise), Saint Germain: Association française d'Archéologie mérovingienne.

Legoux, R. 2005 La Nécropole Mérovingienne de Cutry, Saint-Germain-en-Laye: Association française d'archéologie mérovingienne.

Legoux, R. and Ben Redjeb, T. 2007 'La nécropole mérovingienne de Saint-Sauveur (Somme)' Revue Archéologique De Picardie 1(1), 39-

332. https://doi.org/10.3406/pica.2007.3129

Legoux, R., Périn, P. and Vallet, F. 2004 Chronologie normaliseé du mobilier funéraire mérovingien entre Manche et Lorrraine, Association française d'archéologie mérovingienne.

Leithäuser, U. 2011 Das merowingerzeitliche Gräberfeld Dirmstein, Kreis Bad Dürkheim, Bonn: Habelt.

Leitz, W. 2002 Das Gräberfeld von Bel-Air bei Lausanne: Frédéric Troyon (1815-1866) und die Anfänge der Frühmittelalterarchäologie, Lausanne: Cahiers d'archéologie romande.

Lemière, J. and Levalet, D. 1980 'Saint-Martin-de-Verson (Calvados), nécropole des viie et viiie siècles' Archéologie médiévale 10, 59-

104. https://doi.org/10.3406/arcme.1980.1366

Lethbridge, T.C. 1931 Recent Excavations in Anglo-Saxon Cemeteries in Cambridgeshire and Suffolk, Cambridge: Cambridge Antiquarian

Society. https://archaeologydataservice.ac.uk/library/browse/issue.xhtml?recordld=1160 915\&recordType=MonographSeries

Lethbridge, T.C. 1936 A Cemetery at Shudy Camps, Cambridgeshire : Report of the Excavation of a Cemetery of the Christian Anglo-Saxon Period in 1933, Cambridge: Cambridge Antiquarian Society: Quarto 
Publications. https://archaeologydataservice.ac.uk/library/browse/issue.xhtml?recordld= 1160914\&recordType=MonographSeries

Liéger, A. and Marguet, R. 1992 'Le cimetière mérovingien de Royaumeix/Menil-laTour', Revue Archéologique de l'Est et du Centre-est 43(1), 99-149.

Liéger, A., Marguet, R. and Guillaume, J. 1984 'Sépultures mérovingiennes de l'abbaye de St.-Evre à Toul (Meurthe-et-Moselle)', Revue Archéologique de l'Est et du Centreest 35, 301-17.

Loveluck, C. 2013 Northwest Europe in the Early Middle Ages, c. AD 600-1150: A Comparative Archaeology, Cambridge: Cambridge University

Press. https://doi.org/10.1017/CBO9781139794725

Loveluck, C. and Tys, D. 2006 'Coastal societies, exchange and identity along the Channel and southern North Sea shores of Europe, AD 600-1000', Journal of Maritime Archaeology 1, 140-69. https://doi.org/10.1007/s11457-006-9007-x

Lucy, S. 1997 'Housewives, warriors and slaves? Sex and gender in Anglo-Saxon burials' in J. Moore and E. Scott (eds) Invisible People and Processes: Writing Gender and Childhood into European Archaeology, London: Leicester University Press. 150-68.

Lucy, S. 2000 The Anglo-Saxon Way of Death, Stroud: Sutton.

Lucy, S., Tipper, J. and Dickens, A. 2009 The Anglo-Saxon Settlement and Cemetery at Bloodmoor Hill, Carlton Colville, Suffolk, Cambridge: Cambridge Archaeological Unit. https://archaeologydataservice.ac.uk/archives/view/eaa/contents.cfm?volume id=1 $\underline{253}$

Malim, T. and Hines, J. 1998 The Anglo-Saxon Cemetery at Edix Hill (Barrington A), Cambridgeshire : excavations 1989-1991 and a summary catalogue of material from 19th century interventions, York: Council for British

Archaeology. https://doi.org/10.5284/1081785

Mantel, E., Bayard, D., Blondiaux, J. and Merleau, M. 1994 'Le cimetière mérovingien d'Haudricourt (Seine-Maritime)', Revue Archéologique De Picardie 1(1), 179-

261. https://doi.org/10.3406/pica.1994.2972

Marti, R. 1990 Das frühmittelalterliche Gräberfeld von Saint-Sulpice VD, Lausanne: Bibliothèque historique vaudoise.

Martin, J.F. 2011 'Le site de Jeoffrécourt à Sissonne (Aisne). Cimetière et unites domestiques du Vle au IXe siècle ap. J.C.', Revue archéologique de Picardie 1-2.

Martin, M. 1988 'Grabfunde des 6. Jahrhunderts aus der Kirche St Peter und Paul in Mels SG', Archäologie Der Schweiz 11(4), 167-80.

Martin, T. 2015 The Cruciform Brooch and Anglo-Saxon England, Boydell and Brewer. 
Martin, T. 2020 'Casting the net wider: network approaches to artefact variation in PostRoman Europe', Journal of Archaeological Method and Theory 27, 86186. https://doi.org/10.1007/s10816-019-09441-x

Massey, J.L. 1980 'Le cimetière mérovingien de Coisy (Somme)', Revue Archéologique de Picardie 7, 292-301. https://doi.org/10.3406/pica.1980.1325

Matthews, C.L. 1962 'The Anglo-Saxon cemetery at Marina Drive, Dunstable', Bedfordshire Archaeological Journal 1, 25-42.

Maury, M., Seguin, G., Doyen. J. and Bessou, M. 2013 'La nécropole du haut Moyen Âge du "Clos II" à Buchères (Aube)', Revue archéologique de l'Est 62, 315-41.

McKinley, J. 2013 'Cremation: excavation, analysis and interpretation of material from cremation-related contexts' in S. Tarlow and L. Nilsson Stutz (eds) The Oxford Handbook of the Archaeology of Death and Burial, Oxford: Oxford University Press. 14771. https://doi.org/10.1093/oxfordhb/9780199569069.001.0001

Meaney, A. and Chadwick Hawkes, S. 1970 Two Anglo-Saxon Cemeteries at Winnall, London: Society for Medieval Archaeology Monograph Series 4.

Moen, M. 2020 'Familiarity breeds remembrance: on the reiterative power of cemeteries', World Archaeology 52(1), 35-

48. https://doi.org/10.1080/00438243.2019.1736137

Mui, S. 2015 'Life after death: shrouded burials in later Anglo-Saxon

England', Archaeological Review from Cambridge 30(1), 150-

56. https://dro.dur.ac.uk/16600/

Mui, S. 2018 Dead Body Language: Deciphering corpse positions in early Anglo-Saxon England, Unpublished PhD thesis, University of Durham. http://etheses.dur.ac.uk/12829/

Müller-Wille, M. 1996 'Königtum und Adel im Spiegel der Grabfunde' in A. Wieczorek (ed) Die Franken: Wegbereiter Europad, Mainz: Verlag Philipp von Zabern. 206-21.

Müssemeier, U., Nieveler, E., Plum, R. and Pöppelmann, H. 2003 Chronologie der merowingerzeitlichen Grabfunde vom linken Niederrhein bis zur nördlichen Eifel, Koln: Rheinland Verlag.

Neuffer-Müller, C. 1983 Der alamannische Adelsbestattungsplatz und die Reihengräberfriedhöfe von Kirchheim am Ries (Ostalbkreis), Stuttgart: Theiss.

Neuffer-Müller, C. and Ament, H. 1973 Das fränkische Gräberfeld von Rübenach: Stadt Koblenz, Berlin: Mann.

Nice, A. 2008 La Nécropole Mérovingienne de Goudelancourt-Lès-Pierrepont (Aisne), Amiens: Société archéologique de Picardie. https://doi.org/10.3406/pica.2009.3157

Päffgen, B. 1992 Die Ausgrabungen in St. Severin zu Köln, Mainz am Rhein: von Zabern. 
Paresys, C. 2010 .Fouille d'un Cimetière Mérovingien: Savigny-sur-Ardres, (Marne), "la Croix Cassée": rapport de fouilles, Metz: Inrap GEN.

Parfitt, K. and Anderson, T. 2012 Buckland Anglo-Saxon Cemetery, Dover: excavations 1994, Canterbury: Canterbury Archaeological Trust.

Parfitt, K. and Brugmann, B. 1997 The Anglo-Saxon Cemetery on Mill Hill, Deal, Kent, London: Society for Medieval Archaeology Monograph Series 14.

Paulsen, P. and Schach-Dörges, H. 1978 Das alamannische Gräberfeld von Giengen an der Brenz (Kreis Heidenheim), Stuttgart: Müller \& Gräff.

Pelichet, E. 1952 'La necropole barbare de Saint-Prex (Vaud)', Ur-Schweiz 16, 58-59.

Penn, K. 2000 Excavations on the Norwich Southern Bypass, 1989-91. Part II, the Anglo-Saxon cemetery at Harford Farm, Caistor St Edmund, Norfolk, Dereham: Norfolk Museum

Service. https://archaeologydataservice.ac.uk/archives/view/eaa/contents.cfm?volume i $\underline{d}=1215$

Penn, K. and Anderson, S. 2011 The Anglo-Saxon Cemetery at Shrubland Hall Quarry, Coddenham, Suffolk, Bury St Edmunds: Suffolk County Council Archaeological Service. http://eaareports.org.uk/publication/report139/

Pescheck, C. and Hundt, H. 1996 Das fränkische Reihengräberfeld von Kleinlangheim, Lkr. Kitzingen/Nordbayern, Mainz am Rhein: P. von Zabern.

Peytremann, E. 2008 'La nécropole de Métrich à Kœnigsmacker (Moselle)' in J. Guillaume and E. Peytremann (eds) L'Austrasie: Sociétés, économies, territoires, christianisation: Actes des XXVle Journées internationales d'archéologie mérovingienne, Nancy 22-25 septembre 2005, Nancy: Presses Universitaires de Nancy. 257-268.

Peytremann, E., Boës, E. and Manfredi-Gizard, S. 1999 'Nécropole et habitat rural du haut Moyen Âge à Vellechevreux (Haute-Saône)', Revue archéologique de l'Est 50, 293344.

Philp, B. 2002 The Anglo-Saxon Cemetery at Polhill, near Sevenoaks, Kent 1964-1986, West Wickham: Kent Archaeological Rescue Unit.

Philp, B. and Cheney, M. 1998 Prehistoric and Monastic Sites at Minster Abbey, Sheppey, Kent: the discovery and excavation of two major sites ahead of the construction of the church hall, 1987-88, West Wickham: Kent Archaeological Rescue Unit.

Piepers, W. 1963 'Ein fränkisches Gräberfeld bei Lamersdorf, Kreis Düren', Bonner Jahrbücher 163, 424-68.

Pilet, C., Bagousse, A.A., Blondiaux, J., Buchet, L., Grévin, G. and Pilet-Lemiere, J. 1990 'Les nécropoles de Giberville (Calvados) fin du Ve siècle-fin du VIle siècle ap. JC', Archéologie médiévale 20, 3-140. https://doi.org/10.3406/arcme.1990.972 
Pirling, R. and Grodde, B. 1997 Das römisch-fränkische Gräberfeld von Krefeld-Gellep 1975-1982, Stuttgart: Steiner.

Pirling, R. and Hollstein, E. 1979 Das römisch-fränkische Gräberfeld von Krefeld-Gellep 1964-1965, Berlin: Mann.

Pirling, R., Hundt, H. and Winter, B. 1989 Das römisch-fränkische Gräberfeld von Krefeld-Gellep 1966-1974, Stuttgart: Steiner Verlag Wiesbaden.

Pirling, R. and Siepen, M. 2000 Das römisch-fränkische Gräberfeld von Krefeld-Gellep 1983-1988, Stuttgart: Steiner.

Pirling, R., Siepen, M., Noeske-Winter, B. and Tegtmeier, U. 2003 Das römischfränkische Gräberfeld von Krefeld-Gellep 1989-2000, Stuttgart: F. Steiner.

Piton, D. and Schuler, R. 1981 'La nécropole de Nouvion-en-Ponthieu (Somme) IV-Vle siècle', Revue Archéologique de Picardie 8, 217-

84. https://doi.org/10.3406/pica.1981.1338

Porte, P. and Buchet, L. 1985 'La nécropole du haut Moyen Âge des Grands Peupliers à Hières-sur-Amby. Étude d'une population dans son territoire', Archéologie médiévale 15, 31-102. https://doi.org/10.3406/arcme.1985.1147

Privati, B. 1983 La nécropole de Sézegnin, Geneva: A. Jullien.

Rahtz, P. and Hirst, S. 1974 Beckery Chapel, Glastonbury, 1967-8, Glastonbury: Glastonbury Antiquarian Society.

Rainsford, C. 2021 'One hoof in the grave? Animal remains as inhumation grave goods in early medieval eastern England', Archaeological Journal 178(1), 146-

65. https://doi.org/10.1080/00665983.2020.1864613

Richardson, A. 2005 The Anglo-Saxon Cemeteries of Kent, Oxford: British Archaeol. Rep. British Series 391.

Rodwell, W. 1985 Rivenhall: Investigations of a villa, church and village 1950-1977, London: Chelmsford Archaeological Trust and the Council for British

Archaeology. https://doi.org/10.5284/1081801

Rodwell, W. 2001 Wells Cathedral: Excavation and structural studies 1978-93, London: English

Heritage. https://archaeologydataservice.ac.uk/archives/view/eh monographs 2014/con tents.cfm?mono $=1089080$

Roosens, H. 1978 'Het Merovingisch Grafveld van Rosmeer', Archaeologia Belgica 204.

Roosens, H. and Alenus-Leclerf, J. 1965 'Sépultures mérovingiennes au 'vieux cimetière' d'Arlon', Archaeologia Belgica 88.

Roosens, H., de Boe, G. and de Meulemeester, J. 1976 'Het Merovingisch Grafveld van Rosmeer', Archaeologia Belgica 188. 
Roth, H. 1982 'Ein Reihengräberfeld bei Fellbach-Schmiden, Rems-MurrKreis', Fundberichte Aus Baden Württemberg 7, 491-540.

Routier, J., Legoux, R. and Thuillier, F. 2008 'La nécropole mérovingienne de Bloville (commune de Campagne-les-Hesdin, Pas-de-Calais)', Revue Du Nord 378(5), 93156. https://doi.org/10.3917/rdn.378.0093

Sage, W. and Helmuth, H. 1996 Das Reihengräberfeld von Altenerding in Oberbayern, Berlin: Mann.

Sasse, B. 2001 Ein frühmittelalterliches Reihengräberfeld bei Eichstetten am Kaiserstuhl, Stuttgart: Kommissionsverlag K. Theiss.

Sayer, D. 2020 Early Anglo-Saxon Cemeteries: Kinship, community and identity, Manchester: Manchester University Press. https://doi.org/10.7765/9781526153845

Schach-Dörges, H. 2004 Das frühmittelalterliche Gräberfeld bei Aldingen am mittleren Neckar, Stuttgart: Konrad Theiss Verlag.

Schafer, M. 2005 'Ein Gräberfeld der Merowingerzeit bei Bad Mingolsheim (Gemeinde Bad Schonborn, Landkreis Karlsruhe)', Fundberichte Aus Baden Württemberg 28(1), 319-546.

Schiek, S. 1992 Das Gräberfeld der Merowingerzeit bei Oberflacht, Stuttgart: K. Theiss.

Schimd, D. 1992 'Das alamannische Gräberfeld von Schelklingen, Alb-DonauKreis', Fundberichte Aus Baden Württemberg 17(1), 441-520.

Schneider, J. 1983 'Deersheim. Ein völkerwanderungszeitliches Gräberfeld im Nordharzvorland', Jahresschrift für mitteldeutsche Vorgeschichte 66, 75-358.

Schnurbein, A. 1987 Der alamannische Friedhof bei Fridingen an der Donau (Kreis Tuttlingen), Stuttgart: Theiss.

Scholkmann, B. 1981 'Die Grabungen in der evangelischen Mauritiuskirche zu Aldingen, Landkreis Tuttlingen', Forschungen Und Berichte Der Archaologie Des Mittelalters in Baden-Wurttemberg 7, 223-302.

Schwab, H., Buchiller, C. and Kaufmann, B. 1997 Vuippens-La Palaz: Le site galloromain et la nécropole du Haut Moyen Âge, Fribourg, Suisse: Editions Universitaires.

Scull, C. 2013 'Burial practice in Anglo-Saxon England' in J. Hines and A. Bayliss (eds) Anglo-Saxon Graves and Grave Goods of the 6th and 7th Centuries AD: a chronological framework, London: Society for Medieval Archaeology. 523-29.

Scull, C. 2015 'Chronology, Burial and Conversion: the case of England in the Seventh Century', Neue Studien zur Sachsenforschung 5, 73-84.

Semple, S. and Brookes, S. 2020 'Necrogeography and necroscapes: living with the dead', World Archaeology 52(1), 1-15. https://doi.org/10.1080/00438243.2020.177943 
Sherlock, S., Welch, M. and Birkett, D. 1992 An Anglo-Saxon Cemetery at Norton Cleveland, London: Council for British Archaeology. https://doi.org/10.5284/1081683

Siegmund, F. 1998 'Social structure and relations' in I. Wood (ed) Franks and Alamanni in the Merovingian Period: an ethnographic perspective, Woodbridge: Boydell Press. 177-98.

Smith, R.A. 1912 'On the excavation by Canon Greenwell, FSA, in 1868, of an AngloSaxon cemetery at Uncleby, East Riding of Yorkshire', Proceedings of the Society of Antiquaries of London 2nd Series 24, 146-58.

Soulat, J. 2013 'A study of Merovingian-type grave-goods in Kent: a first approach' in B. Ludowici (ed) Individual and Individuality: Approaches towards an Archaeology of Personhood in the First Millenium AD, Stuttgart: Konrad Theiss. 205-16.

Soulat, J. Bocquet-Liénard, A. Savary, X. and Hinckner, V. 2012 'Hand-made pottery along the Channel coast and parallels with the Scheldt valley' in L. Verslype, R. Annaert, K. De Groote, Y. Hollevoet, F. Theuws, and D. Tys (eds) The Very Beginning of Europe? Cultural and social dimensions of Early-Medieval migration and colonisation (5th-8th century). Archaeology in Contemporary Europe Conference, Brussels - May 17-19, 2011, Brussels: Flanders Heritage Agency. 215-224.

Steane, K. 1991 'St-Paul-in-the-Bail: a dated sequence', Lincoln Archaeology 3, 28-31.

Steiner, L. and Klausener, M. 2011 La Nécropole du Clos d'Aubonne à La Tour-de-Peilz (Canton de Vaud), Lausanne: Cahiers d'archéologie romande.

Stoodley, N. 1999 The Spindle and the Spear: a critical enquiry into the construction and meaning of gender in the early Anglo-Saxon burial rite, Oxford: British Archaeol. Rep. 288.

Stutz, F., Filomena Guerra, M. and Calligaro, T. 2008 'Le cimetière mérovingien sous l'eglise Saint-Saturnin, à Chasseneuil-sur-Bonnieure (Charente): Présentation typologique et analyses morphologiques de trois parures féminines privilégiées' in J. Guillaume and E. Peytremann (eds) L'Austrasie: Sociétés, économies, territoires, christianisation: Actes des XXVle Journées internationales d'archéologie mérovingienne, Nancy 22-25 septembre 2005, Nancy: Presses Universitaires de Nancy. 415-431.

Suhr, G. 2010 'Das frühmittelalterliche Gräberfeld von München-

Sendling/Brudermühlstraße', Bericht Der Bayerischen Bodendenkmalpflege 51, 407-28.

Tester, A., Anderson, S., Riddler, I. and Carr, R. 2013 Staunch Meadow, Brandon, Suffolk: a high status Middle Saxon settlement on the fen edge, Norwich: East Anglian Archaeology 151. http://eaareports.org.uk/publication/report151/

Theune, C. 1999 'On the chronology of Merovingian-period grave goods in Alamannia' in J. Hines, K. Høilund Nielsen and F. Siegmund (eds) The Pace of Change: studies in early Medieval chronology, Oxford: Oxbow Books. 23-32.

Theune, C. 2004 Germanen und Romanen in der Alamannia: Strukturveränderungen aufgrund der archäologischen Quellen vom 3. bis zum 7. Jahrhundert, Berlin: W. de Gruyter. https://doi.org/10.1515/9783110908190 
Theuws, F. 1999 'Changing settlement patterns, burial grounds and the symbolic construction of ancestors and communities in the late Merovingian southern Netherlands' in C. Fabceh and J. Ringtved (eds) Settlement and Landscape: Proceedings of a Conference in Århus Denmark, May 4-7 1998, Højbjerg: Jutland Archaeological Society. 337-349.

Theuws, F. 2009 'Grave goods, ethnicity, and the rhetoric of burial rites in late antique northern Gaul' in T. Derks and N. Roymans (eds) Ethnic Constructs in Antiquity: the Role of Power and Tradition, Amsterdam: Amsterdam University Press. 283319. https://doi.org/10.5117/9789089640789

Theuws, F. and Kars, M. 2017 The Saint-Servatius Complex in Maastricht: The Vrijthof excavations (1969-1970): Roman infrastructure - Merovingian cemetery: Carolingian cemetery - early town development, Bonn: Habelt Verlag.

Theuws, F., Haperen, M., Brandenburgh, C., Panhuysen, R., Smits, L. and Lith, S. 2012 The Merovingian Cemetery of Bergeijk-Fazantlaan, Bonn: Habelt-Verlag.

Thomann, E. and Waton, M. 2008 'Une nécropole alto-médiévale en Basse-Alsace: Wasselonne, lieudit Wiedbiehl' in J. Guillaume and E. Peytremann (eds) L'Austrasie: Sociétés, économies, territoires, christianisation: Actes des XXVIe Journées internationales d'archéologie mérovingienne, Nancy 22-25 septembre 200/5, Nancy: Presses Universitaires de Nancy. 289-94.

Timby, J. and Bartlett, A. 1996 The Anglo-Saxon Cemetery at Empingham II, Rutland: excavations carried out between 1974-1975, Oxford: Oxbow Books.

Timpel, W. 1990 'Das fränkische Gräberfeld von Alach, Kreis Erfurt', Alt-Thüringen 25, 61-155.

Timpel, W. and Spazier, I. 2014 Corpus archäologischer Quellen des 7.-12. Jahrhunderts in Thüringen, Langenweibetabach: Kommissionverlag Beir \& Beran Archäologische Fachliteratur.

Tyler, S. 1988 'The Anglo-Saxon cemetery at Prittlewell, Essex: an analysis of the grave goods', Essex Archaeology and History 19, 91-116.

Urlacher, J., Passard, F. and Manfredi-Gizard, S. 1998 La nécropole mérovingienne de la Grande Oye à Doubs: département du Doubs: VIe-VIle siècles après J.C, SaintGermain-en-Laye: Association française d'archéologie mérovingienne.

Urlacher, J.P., Passard-Urlacher, F. and Gizard, S. 2008 Saint-Vit, les Champs Traversains, Doubs: nécropole mérovingienne, VIe-VIle siècle ap. J.-C. et enclos protohistorique, IXe-Ve siècle av. J.-C, Besançon: Presses Universitaires de FrancheComté.

Van Es, W. 1964 'Het Rijengrafveld van Wageningen', Palaeohistoria 10, 181-316.

Van Es, W., Hulst, R., Kars, H., Moormann, E. and Teunissen, D. 1991 Das Merowingische Gräberfeld von Lent, Amersfoort: ROB. 
Vanderhoeven, M. 1977 'Een Merovingisch Grafveld to Engelmanshoven', Archaeologia Belgica 194.

Verstegen, U. 2006 Ausgrabungen und Bauforschungen in St Gereon zu Köln, Mainz am Rhein: P. von Zabern.

Villier, S. 2013 Occupation Antique, Médiévale et Moderne au Cœur de la Bourgade de Mars-la-Tour: Mars-la-Tour, Meurthe-et-Moselle, Suivi d'un projet d'assainissement Rue du 16 août 1870, rue de la Fontaine, rue de Verdun et de Metz: rapport technique et d'expertise, Metz, Inrap GEN.

Walton Rogers, P. and Allen, S. 2013 Tyttel's Halh: the Anglo-Saxon Cemetery at Tittleshall, Norfolk: the archaeology of the Bacton to King's Lynn gas pipeine, Volume 2. Lincoln: Network Archaeology. http://eaareports.org.uk/publication/report150/

Wagner, A. and Ypey, J.. 2012/ Das Gräberfeld auf dem Donderberg bei Rhenen/ Leiden: Sidestone Press.

Warhurst, A. 1955 'The Jutish cemetery at Lyminge', Archaeologia Cantiana 69, 1 40. https://kentarchaeology.org.uk/node/11186

Wedlake, W. 1958 Excavations at Camerton, Somerset: A record of excavation covering the period from Neolithic to Saxon times; 1926-56, Camerton: Camerton Excavation Club.

Weis, M. 1999 Ein Gräberfeld der späten Merowingerzeit bei Stetten an der Donau, Stuttgart: Kommissionsverlag K. Theiss.

Welch, M. 2011 'The Mid Saxon "Final Phase"' in H. Hamerow, D. Hinton and S. Crawford (eds) The Oxford Handbook of Anglo-Saxon Archaeology, Oxford: Oxford University Press. 266-87. https://doi.org/10.1093/oxfordhb/9780199212149.013.0015

Werner, J. 1955 Das alamannische Gräberfeld von Mindelheim, Augsburg: Verlag der Schwäbischen Forschungsgemeinschaft.

Wickham, C. 2006 Framing the Early Middle Ages: Europe and the Mediterranean, 400800, Oxford: Oxford University

Press. https://doi.org/10.1093/acprof:oso/9780199264490.001.0001

Will, M. 1994 'Das frühmittelalterliche Gräberfeld von Dachwig, Lkr. Gotha', AltThüringen 28, 171-212.

Williams, H. 2005 'Cremation in early Anglo-Saxon England - past, present and future research' in H-J. Häßler (ed) Studien zur Sachsenforchung 15, Oldenburg: Isensee. 53349.

Williams, H. 2006 Death and Memory in Early Medieval Britain, Cambridge: Cambridge University Press. https://doi.org/10.1017/CBO9780511489594

Windler, R. and Langenegger, E. 1994 Das Gräberfeld von Elgg und die Besiedlung der Nordostschweiz im 5.-7. Jh, Zurich: Kommissionsverlag Fotorotar AG. 
Ypey, J. 1964 'Die Funde aus dem frühmittelalterliche Gräberfeld Huinerveld bei Putten im Museum Nairac in Barneveld', Berichten van de Rijksdienst voor het Oudheidkundig Bodemonderzoek 12-13, 99-152.

Zintl, S. 2013 'Die Datierung von Gräbern in Regensburg-Burgweinting - Implikationen für archäologische Modelle von Chronologie und Austattung in der jüngeren und späten Merowingerzeit', Bericht der Bayerischen Bodendenkmalpflege 54, 389-96. 